\title{
ASSESSMENT OF PROPOSED FEDERAL TAX CREDITS FOR RESIDENTIAL WOOD BURNING EQUIPMENT
}

U.S. DEPARTMENT OF ENERGY

DIVISION OF BUILDINGS AND COMMUNITY SYSTEM

TECHNOLOGY AND CONSUMER

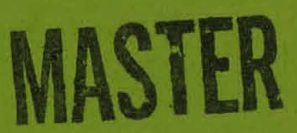

\section{PRODUCTS BRANCH}

PRODUCTS BRANCH

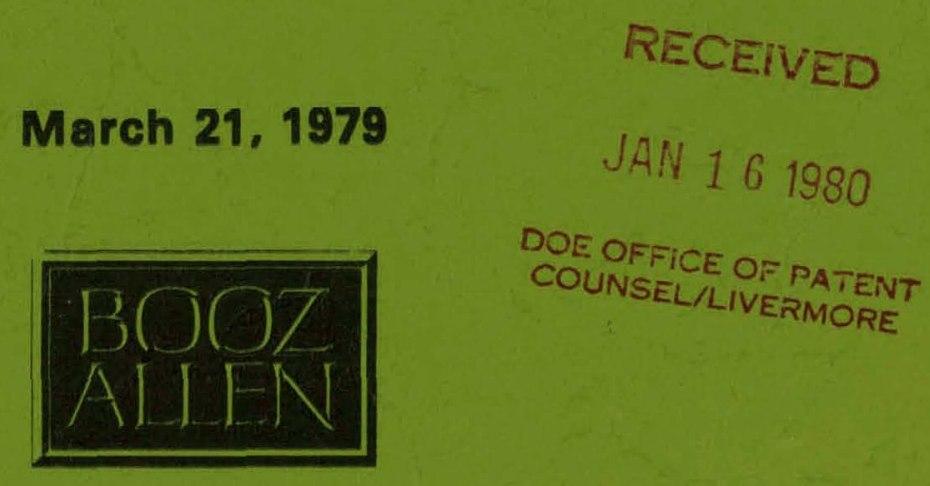




\section{DISCLAIMER}

This report was prepared as an account of work sponsored by an agency of the United States Government. Neither the United States Government nor any agency Thereof, nor any of their employees, makes any warranty, express or implied, or assumes any legal liability or responsibility for the accuracy, completeness, or usefulness of any information, apparatus, product, or process disclosed, or represents that its use would not infringe privately owned rights. Reference herein to any specific commercial product, process, or service by trade name, trademark, manufacturer, or otherwise does not necessarily constitute or imply its endorsement, recommendation, or favoring by the United States Government or any agency thereof. The views and opinions of authors expressed herein do not necessarily state or reflect those of the United States Government or any agency thereof. 


\section{DISCLAIMER}

Portions of this document may be illegible in electronic image products. Images are produced from the best available original document. 


$$
\text { EC-77-C-03-1693 BCS TASK * OS9 }
$$

March 21, 1979

\title{
ASSESSMENT OF PROPOSED FEDERAL TAX CREDITS FOR RESIDENTIAL WOOD BURNING EQUIPMENT
}

\author{
Prepared for: \\ THE DEPARTMENT OF ENERGY \\ DIVISION OF BUILDINGS AND COMMUNITY SYSTEMS \\ TECHNOLOGY AND CONSUMER PRODUCTS BRANCH
}

luY

BOOZ - ALLEN \& HAMILTON, InC.

4330 East west Highway

Bethesda, MD 20014

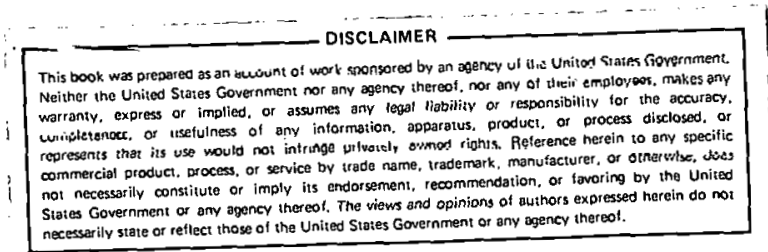

Revised November 30,1979 
NOTICE

This report was prepared as an account of work sponsored by an agency of the united States Government. Neither the United States nor any agency tinereoI, nor any nf theif cmployees, lidkes any warranty, expressed or implied, or assumes any legal liability or responsibility for any third party's use or the results of such use of any information, apparatus, product or process disclosed in this report, or represents that its use by such third party wolild not inzringe privately-owned rights. 
T A B L E O F C O N T E N T S

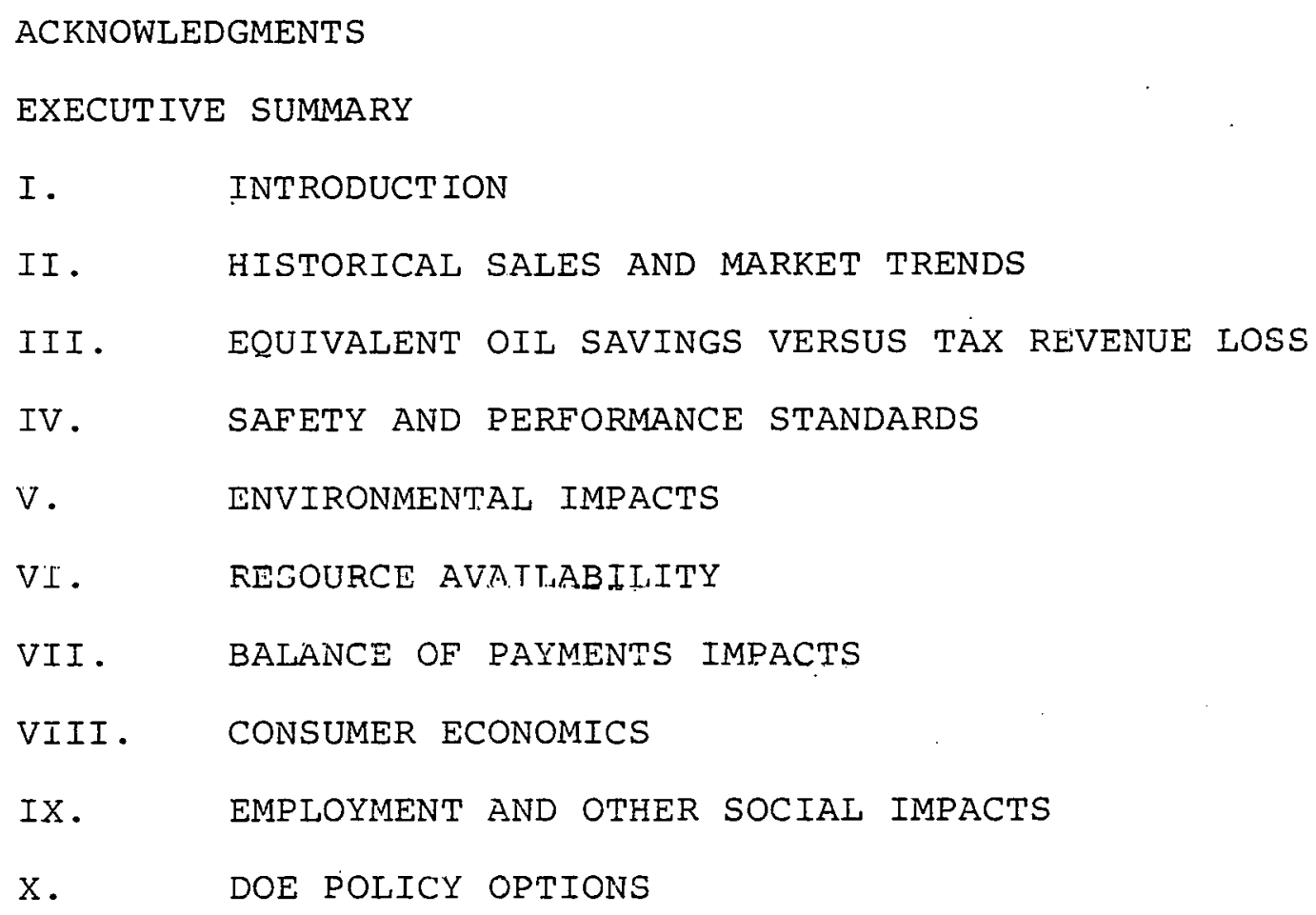


T A B L E O F E X H I B I T S

Exhibit

Number

II- 1 Major Types of Residential Wood Heating Equipment

II-2 Historical Production and Shipment Data For Residential Wood Burning Equipment

II-3 Wood Burning Equipment Prices and Performance Assumptions

III- 1.

III-2

III -3

III -4

III-5

$$
\text { Oi }
$$
Combinations

Example Calculation of Annual Equivalent oil Savings and Tax Revenue Loss

BA\&H Base Sales Frojections Through 1985 For Residential Wood Burning Equipment

Oil Savings Versus Tax Revenue Loss For Wood Burning Equipment

Oil Savings Versus Tax Revenue Loss

$I V-1$

Coverage and Status of U.I. Standards For Wood Burning Equipment

IV-2 . Causes of Fires Attributed to Wood IV-6 Burning

IV -3

$\mathrm{V}-1$

$\mathrm{V}-2$

General Categories of Efficiency . Variables For Wood Burning Equipment

Following Page Number

II-2

II -4

II -7

III -4

III-8

III-II

III -11

III-11

IV -3

IV-9

$V-7$ wood, Coal, Gas and Oil Combustion

$\mathrm{V}-9$ Fossil Fuels and Biomass 
Exhibit

Number

$\mathrm{V}-3$

$\mathrm{V}-4$

$\mathrm{V}-5$

VI-I

$\mathrm{VI}-2$

$\mathrm{VI}-3$

VII- 1

VIII- I

VIII-2

$x-1$
Input of $\mathrm{CO}_{2}$ Into The Atmosphere From Nonfossil Woodburning and Other Sources

Comparison of Emission Factors of Wood Combustion Devices

Potential Increases in Particulate Matter From Wood Burning StovesBased on Butcher's 1978 Study

Potential Fuelwood Sources

$$
\mathrm{VI}-3
$$

Potentially Available Wood Resource By USDA Farm Production Regions (1976)

Wood Utilization

$$
\mathrm{VI}-5
$$

Aggregate Plant Capacity for Major U.S. Producers of Cast Iron Stoves

VII-2

Wood Heating Fuel Cost Comparison

VTII- 1

Annualized Costs For Selected Residential Heating Systems

VIII-3

Alternative Policy Options and Suboptions $x-2$ 


\section{ACKNOWLEDGMENTS}

This study was prepared for the Department of Energy by Booz, Allen \& Hamilton Inc. Dr. Kurt W. Riegel, Chief of Technology and Consumer Products Branch was the technical project officer for DOE. At Booz, Allen \& Hamilton, the project team included David L. Hartman, Project Manager, Heather Burns, David Croyle and David Friedman. Penny Piper coordinated typing production. Dr. Alan S. Hirshberg was the Research Director ard Dr. John P. Henry, Jr., the officer in charge.

Many persons knowledgable on the stove and fireplace technology and industry have made invaluable contributions to the successful completion of the study, especially:

Mrs. Pauline Dunckel, Consultant

Mr. John Lynn, Fisher Stoves

Mr. Andrew Shapiro, Wood Energy Institute

Mr. Richard Peacock, National Bureau of

Standards

Dr. Jay Shelton, Williams College

Dr. David Salo, Mitre Corporation

Mr. William Quinn, Preway Fireplaces.

In addition, completion of the study would not have been possible without the cooperation and assistance of U.S. International Trade Commission, Underwriters Laboratory, Fireplace Institute, The National Wood Stove and Fireplace Journal, and many people from the Department of Energy including Dr. Jorgen Birkeland, Mr. Ron White, Mr. Jim Dollard, Mr. Gerald Leighton and Mr. John Ryan.

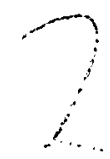




\section{EXECUT IVE · SUMMARY}

The final version of the National Energy Act (passed October 15, 1978) did not include tax credits for residential wood burning equipment. However, earlier versions did provide eligibility for wood stoves. In response to a high level of public and congressional interest in wood energy, Secretary James Schlesinger, in a letter to Senator McIntyre, committed the Department of Energy to conduct a policy review of whether tax credits should be provided under the Energy $\mathrm{Tax}$ Act of 1978 to individuals who purchase wood burning equipment for home heating. Under the NEA legislation, DOE can recommend to the Internal Revenue Service (IRS) additional items of equipment for conservation and renewable energy tax credits.

To assist in this review, DOE requested Booz, Allen \& Hamilton Inc., to prepare a comprehensive analysis study which could be used as a basis for a DOE policy recommendation. This document summarizes the key findings of this analysis.

\section{APPROACH AND ORGANIZATION OF THE REPORT}

A wide variety of issues have been raised regarding the eligibility of residential wood burning equipment for tax credits. This study specifically addressed the following major issues:

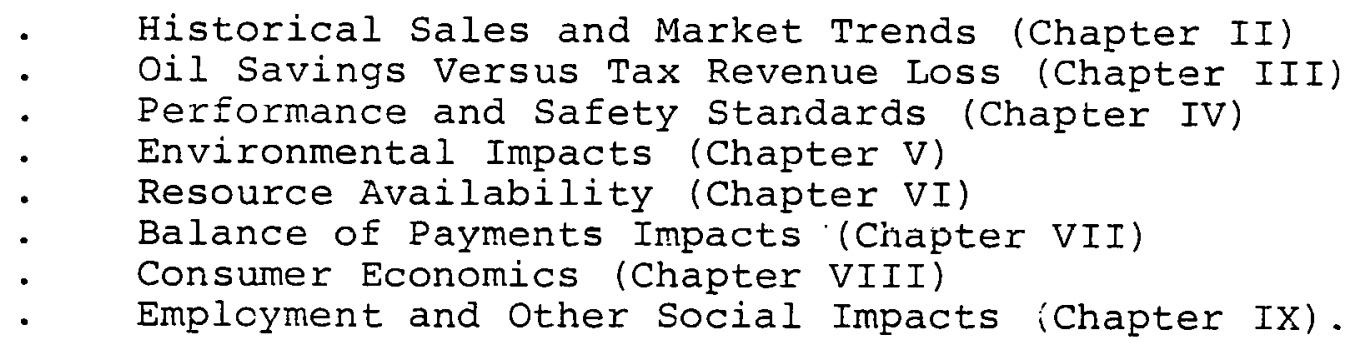

The study concludes with a chapter which identifies the pros and cons of various DOE policy options.

\section{MAJOR FINDINGS AND CONCLUSIONS}

The major findings and conclusions of the report are summarized in this section. 


\section{(1) Historical Sales and Market Trends}

There are four major types of wood burning equipment on the market:

$$
\begin{aligned}
& \text { - Air-tight stoves-including thermostatic } \\
& \text { circulators and radiant heaters. } \\
& \text { - Traditional stoves-including franklin, } \\
& \text { box, parlor and cooking types. } \\
& \text { Boilers and furnaces-including dual } \\
& \text { fuel units and add-on styles. } \\
& \text { - Pireplaces-including built-in masonry } \\
& \text { and zero clearance units plus free } \\
& \text { standing metal units. }
\end{aligned}
$$

Sales of residential wood burning equipment have grown substantially since 1972 (see Exhibit I)

- In 1978 stove sales were approximately 1.1 million units compared to under 200 thousand units in 1972 .

- Dollar volume for stoves, chimneys, accessories and installation were approximately $\$ 1$ billion at the retail level in 1978 .

- Industry estimates of sales for wood burning boilers and furnaces were approximately 50,000 units.

- Industry estimates for fireplace sales were upwards of 1.5 million units of all types.

- Domestic production accounts for 65 percent of stove, furnace and boiler sales; the balance are imported. Almost all fireplaces are domestically produced.

Wood fuel is now used in upwards of five percent of U.S. households for part or all of the space heating requirements

- About one million homes currently use wood as a primary fuel.

- An additional four million homes may be using wood for supplemental heat. 
- The potential market for wood fuel usage appears to be in the range of 10 to 15 million homes by 1985 .

(2)

\section{Consumer Economics}

Based on current wood fuel costs, wood heating is slightly cheaper than oil or electric heat pump heating

- At typical 1978/1979 market prices of $\$ 60 /$ cord, wood heating competes with oil at $50 \mathrm{c} / \mathrm{gal}$. and electric heat pumps at $4 \mathrm{c} / \mathrm{kWh}$.

- Wood heating can not generally compete with natural gas but is much more economical than electric resistance heat.

Wiien equipment amortization costs and maintenance are included, wood heating becomes more expensive and is generaliy uneconomic compared to conventional fuels

- Equipment costs add 10 to 20 percent to the cost of wood fuel.

- Required maintenance, primarily chimney cleaning, adds another 5 to 10 percent.

In terms of the overall effect on wood heating economics, equipment tax credits will have a small but beneficial impact on annual wood heating costs

- Tax credits will reduce the annualized heating costs by approximately 5 percent.

- Tax credits do have a significant effect on a taxpayers cash flow and on reducing equipment payback period.

- Where penple cut their own wood supply, (and this is the case for about 50 percent of wood burners), tax credits will have a relatively greater impact since the prime economic consideration here is on equipment not fuel costs. 
- Tax credits will likely have a considerable promotional value.

(3) Oil Savings Versus Tax Revenue Loss

\begin{tabular}{l} 
The potential incremental oil savings from \\
tax credits is about lo million bbl oil \\
equivalent per year but this depends on the \\
level of the incentive and the type of \\
\hline eligible equipment (See ExhibitII, column 3) \\
- Two levels of tax credits were con- \\
sidered in the analysis-30 percent \\
renewable energy credits and l5 per- \\
cent conservation credits. These \\
two types of credits are part of the \\
NEA and expire in l985. \\
Research on incentives indicates that \\
tax credits for wood burning equipment \\
are expected to result in a sales in- \\
crease approximately equal to the tax \\
credit level. * \\
The l5 percent tax credit results in \\
a public oil savings of l60 million \\
bbl cumulative through 2005 if eligi- \\
bility is limited to airtight stoves \\
and furnaces; oil savings doubles for \\
solar tax credits to 320 million bbl. \\
Eligibility of all other stoves increases \\
oil savings by 38 and 75 million bbl \\
respectively. \\
Eligibility of fireplaces increases \\
oil savings by l2 and 24 million bbl \\
respectively. \\
-
\end{tabular}

Based on a review of the available literature, it was determined that a long term demand elasticity of 1.0 was reasonable for this type of equipment. However, conversations with a number of manufacturers indicated that the existence of a tax credit was the prime factor in increasing sales, rather than the level of the credit. 
EXHIBIT I

Historical Production and Shipment Data

For Residential Wood Burning Equipment

$\left(000^{\circ} \mathrm{s}\right)$

\begin{tabular}{|c|c|c|c|c|c|c|c|}
\hline STOVES & & & & & & . & \\
\hline Domestically Produced & 1972 & 1973 & 1974 & 1975 & 1976 & 1977 & 1978 \\
\hline Cast Iron Units (1) & 110 & 140 & 160 & 230 & 120 & 210 & 120 \\
\hline Fabricated Units $(1,3,4)$ & 20 & 40 & 70 & 230 & 330 & 530 & 600 \\
\hline Not Specified & 10 & 10 & 10 & 20 & 20 & 50 & 50 \\
\hline Subtotal & 140 & 190 & 240 & 480 & 470 & 790 & 770 \\
\hline \multicolumn{8}{|l|}{ Imported Units } \\
\hline Europe $(2,4)$ & * & * & * & 30 & 20 & 40 & 70 \\
\hline Asia $(2,4)$ & * & * & * & 170 & 150 & .170 & 300 \\
\hline Not Specified & * & * & $\dot{x}$ & 80 & 30 & 30 & 10 \\
\hline Subtotal & 20 & 20 & 30 & 280 & 200 & 240 & 380 \\
\hline TOTAL STOVES & 160 & 210 & 340 & 760 & 670 & 1030 & 1150 \\
\hline FURNACES AND BOILERS (1) & * & * & * & * & * & * & 50 \\
\hline \multicolumn{8}{|l|}{ FIREPLACES (1 } \\
\hline Built-in Masonry & * & * & * & * & * & * & 650 \\
\hline Built-in Zero Clearance & * & * & * & * & * & * & 650 \\
\hline Eree Standing & * & * & * & * & * & * & 150 \\
\hline
\end{tabular}

SOURCES :

1. Personal communications with manufacturers and their representatives

2. International Trade Commission

3. Department of Commerce

4. Booz, Allen \& Hamilton estimates

Dèta incomplete or not available 
EXHIBIT II

Oil Savings Versus Tax Revenue Loss For Selected DoE Policy Option Combinations

\begin{tabular}{|c|c|c|c|c|c|c|c|c|}
\hline $\cot$ & POLICY OPTIOATS & $\begin{array}{c}\text { BASE } \\
\text { SAL.ES } \\
\text { 1979-1985 } \\
\text { MIL. UAIITS }\end{array}$ & $\begin{array}{l}\text { MICREMEHTAL } \\
\text { SALEE } \\
\text { MEL. VHHITS }\end{array}$ & 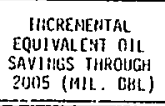 & $\begin{array}{l}\text { ISTAL } \\
\text { SAL.ES } \\
\text { MLL. UNIIS }\end{array}$ & $\begin{array}{l}\text { IAX REVCIUUE } \\
\text { L.OSS } \\
\text { 1979-1985 (SHA1..) }\end{array}$ & 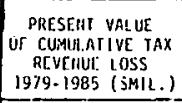 & $\begin{array}{l}\text { PRESEHT VALUE } \\
\text { OF TAX REVERLE LOSS } \\
\text { PER BQD. OOL } \\
\text { SAVEO (S/OBL) } \\
\end{array}$ \\
\hline 1.A.2.0 & $\begin{array}{l}\text { SOLAR IAR CKL:OIT FOR AIRTICHIT } \\
\text { STOVES OHLY }\end{array}$ & 4.0 & 1.2 & 240 & 5.2 & 914 & br9 & 2.87 \\
\hline I.A.C.2.a & $\begin{array}{l}\text { SOLAR TAR CRLOH TOR AIRTIGUT } \\
\text { STOVES AIBO TURHACES }\end{array}$ & 4.7 & 1.4 & 320 & i.1 & 1,597 & 1.106 & 3.64 \\
\hline $1 . A+B+C . P . d$ & $\begin{array}{l}\text { SOLAR TAX CREDIT FOR ALL STONSS } \\
\text { AHD FURIIICES }\end{array}$ & 8.1 & 2.1 & 395 & 10.5 & 2,076 & 1.516 & 3.84 \\
\hline $1 . A+B+C+0.2 . a$ & $\begin{array}{l}\text { SOLAR TAR CACOIT FOR ALL STOVES, } \\
\text { FURAACSS. ANID FIREPLACES }\end{array}$ & 12.0 & 3.0 & 419 & 15.6 & 3.927 & 2.867 & 6.84 \\
\hline$|. A+B+C+B+E .2 . u|$ & 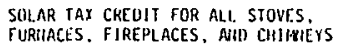 & 12.0 & 3.6 & 419 & 15.6 & 6,987 & 5,101 & 12.17 \\
\hline II.A.2.A & $\begin{array}{l}\text { COHSERYA- 10A VAX CREDII FOR } \\
\text { AIRI IGit STOVES OHIYY }\end{array}$ & 4.0 & 0.6 & 120 & 4.6 & 417 & 304 & 2.53 \\
\hline II.ANC.2.0 & 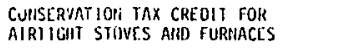 & 4.7 & 0.7 & 100 & 5.4 & 707 & 516 & 3.23 \\
\hline $11 . A+B+C .2 . a$ & $\begin{array}{l}\text { CONSERYAT 10:1 JAX CREDI FOK ALLL } \\
\text { STUYVES AIO FURARCES }\end{array}$ & 8.1 & 1.2 & 198 & 9.3 & 919 & 671 & 3.39 \\
\hline $11 . A+B+C+0.2 . d$ & $\begin{array}{l}\text { COUSERYAT IOI AAX CREUIT FOH ALI } \\
\text { STOVES. FURIIACES. AHID FIREI'LACES }\end{array}$ & 12.0 & 1.8 & 210 & 13.8 & 1.736 & 1,267 & 6.03 \\
\hline $11 \cdot A+B+C+0+E, 2 . a$ & 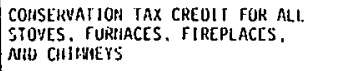 & 12.0 & 1.8 & 210 & 13.8 & 3.370 & 2.460 & 11.71 \\
\hline I.A.C.1.a & 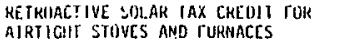 & 5.5 & 1.4 & 320 & 6.9 & 1.797 & 1,312 & 4.10 \\
\hline \multirow[t]{2}{*}{ I.A+C.3.d } & 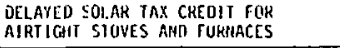 & 4.0 & 1.2 & 280 & 5.2 & $i, 434$ & 1.047 & 3.74 \\
\hline & $\begin{array}{l}\text { INSULAFICW JAX CKEDIY COMPARISOH } \\
\text { SOLAR HOFE J IXX CREOIT COHPRRISOH }\end{array}$ & $\begin{array}{r}16.0 \\
0.5\end{array}$ & $\begin{array}{l}7.8 \\
0.3\end{array}$ & $\begin{array}{r}390 \\
23\end{array}$ & $\begin{array}{r}23.8 \\
0.8\end{array}$ & $\begin{array}{r}2,809 \\
379\end{array}$ & $\begin{array}{r}2,100 \\
262\end{array}$ & $\begin{array}{r}2.42 \\
11.28\end{array}$ \\
\hline
\end{tabular}

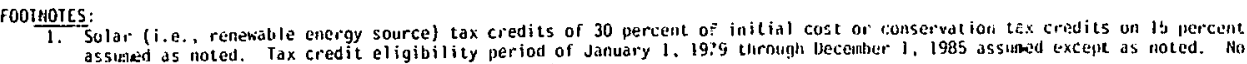

assumed ds noted. Tax creas elightlity period or

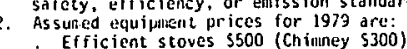

Efficient stoves $\$ 500$ (Chininey 5300$)$
Central furnaces and boilers $\$ 2.000$ (Chimey $\$ 500)$

All other stoves $\$ 3000$ (Chimey $\$ 3000$
f

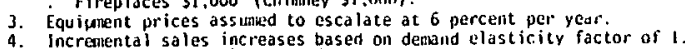

Incremental oll savings bas dod on.

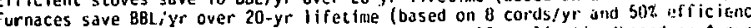

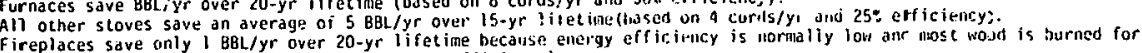
hes thet ic purposes (based on I cord/yr and 208 efficiency).

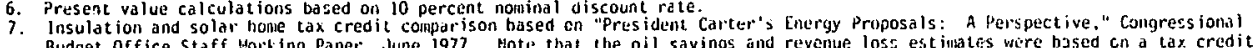

eligibility period of 1977-1984 and on slightly different cax credit percentages.

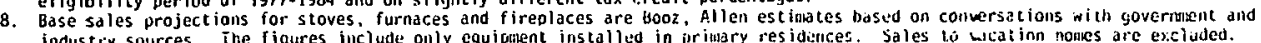

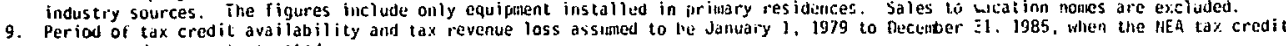

progradue elds. except as note 
The government tax revenue loss resulting from the tax credits is in the range of $\$ 300$ million to $\$ 1.2$ billion but also depends on the level of the incentive and the type of equipment eligible (See ExhibitII, Column 6)

- The 15 percent tax credit results in a direct federal tax revenue loss of $\$ 500$ miliion cumulative through 1985 if eligibility is limited to airtight stoves and furnaces; revenue loss. for solar tax credits is $\$ 1.2$ billion.

- Eligibility of less efficient stoves increases revenue loss by $\$ 200$ million and $\$ 400$ million respectively.

- Eligibility of fireplaces increases revenue loss by $\$ .6$ billion and $\$ 1.2$ billion respectively.

- Chimneys ard another $\$ 1.2$ to 2.5 billion of tax revenue loss.

Tax credits for airtight wood burning stoves and furnaces result in a government cost per private barrel of oil savings slightly higher than home insulation tax credits but much lower than solar home tax Credits (See Exhibit II, Column 7)

- Tax revenue loss per bbl oil is between $\$ 3$ and $\$ 4$ for airtight stoves, furnaces and boilers combined.

- This compares favorably with home insulation tax credits costing $\$ 2.50$ per $b b l$.

- Solar home tax credits cost much more at $\$ 11$ per bbl.

- Built-in fireplaces are generally more expensive than airtight stoves and are somewhat less efficient. As a result the guvernment cost. per bbl oil saved is higher for this option. 
Underwriters Laboratory (UL), in cooperation with the wood burning industry, has developed four equipment safety standards for wood burning equipment

- Three of these standards have been in - place for at least several years and the fourth will be adopted in early 1979 .

- UL and industry representatives expect. compliance with the standards to be high.

Although suitable equipment standards are available, a significant effort is needed to educate consumers on proper operation and maintenance

- Proposed UL standards are designed to primarily alleviate equipment related safety problems.

- Approximately 77 percent of wood burning related fires are due to consumer misuse or improper installation rather than equipment inadequacy.

Industry and government have made considerable progress in developing wood burning equipment efficiency standards, but final performance standards are not yet available

- Development work in efficiency testing procedures is well underway and a first proposed standard is nearly ready.

- It will likely be several years before the over 1,000 models of equipment on the market can be laboratory. tested according to" these standards. 


\section{(5) Environmental Impacts}

Increased wood harvesting has potential negative environmental impacts but these appear to be controllable

- Increased wood cutting and logging activities pose a threat to the quality of nearby water bodies as well as the overall forest environment especially for large operations.

- Many of these negative impacts can be avoided or controlled through the application of sound forest manayement practices.

- Increased wood harvesting can result in positive impacts on wildlife habitat and forest productivity.

Increased wood burning may cause limited air pollution problems primarily in valleys and near urban areas

- Major air pollutants of concern resulting from wood burning are particulates and chemicals.

- Sulphur dioxides, nitrogen oxides, and hydrocarbon emissions from wood burning do not appear to pose air pollution threats.

- Air pollution impacts will be localized and will vary in severity depending or such factors as atmospheric conditions, residential density, and wood burning techniques.

(6) Resource Availability

Potential supplies of fuelwood in this country are vast and with proper management appear capablc of meeting the probable increases in residential demand for wood as an energy source 
- The existing wood supply is sufficient to meet very large increases in demand solely by relying on excess growth and residues from commercial forestry operations.

- A vast potential also can be realized through enhanced forest management.

- Because the distribution systems for fuel wood are not fully developed, spot shortages will occur in some regions.

\section{(7) Balance of Payments}

Tax credits for wood heating equipment are not expected to significantly increase the ratio of imported to domestic sales

- There is substantial excess plant capacity in the U.S. for cast iron stoves; capacity for other types of equipment can be added in a matter of months.

- Rigorous safety and performance standards would exclude many of the current models of imported units from tax credit eligibility.

Reduced foreign oil imports are expected to outweigh imported wood heating equipment in terms of balance of payments

- Over the lifetime of a wood stove or furnace, the dollar value of energy savings when converted to barrels of oil will far exceed the initial purchase price.

- Thus, even if sales of imported equipment does rise during the next few years due to a tax credit program, the reduction in imported oil will soon catch up.*

* For the purpose of this type of policy analysis, DOE assumes that energy savings anywhere in the U.S., will reduce imported oil consumption. 
(8) Employment and Social Impacts

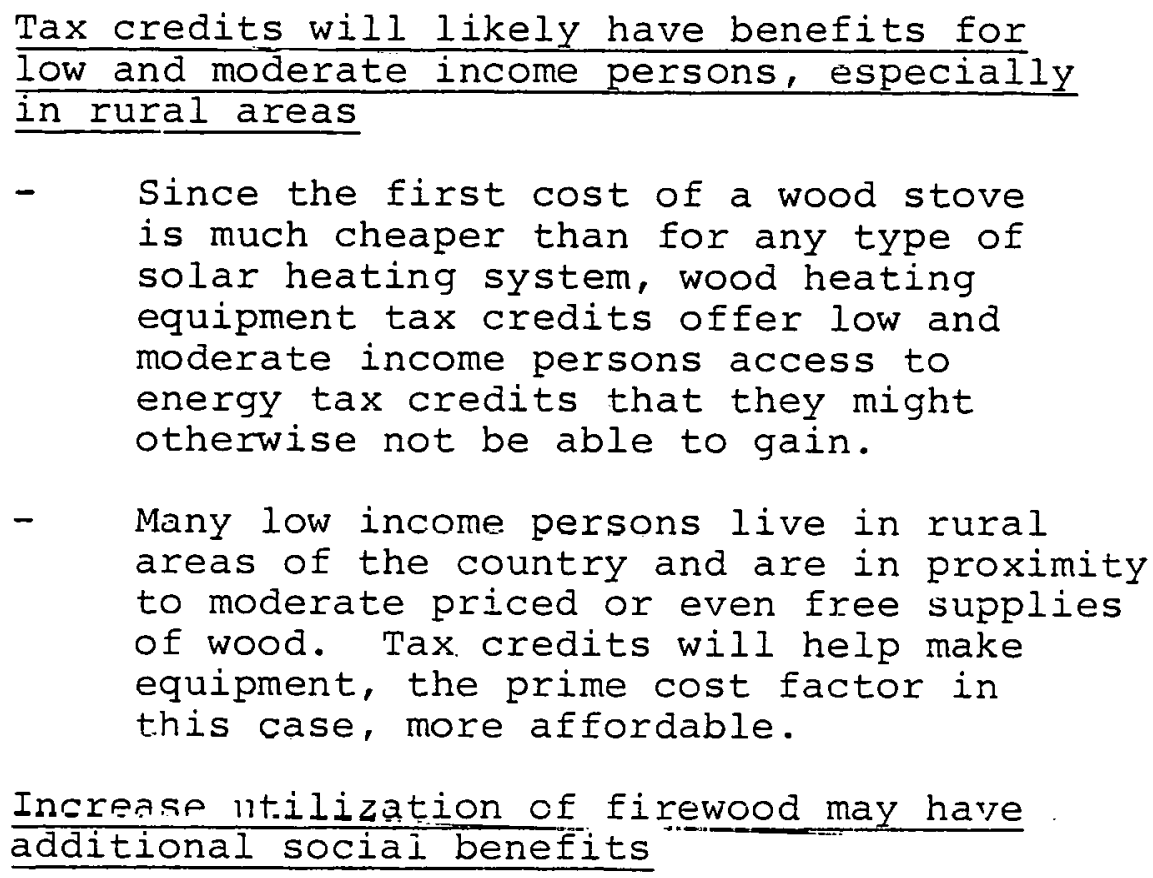

Tax credits will likely have benefits for low and moderate income persons, especially in rural areas

- Since the first cost of a wood stove is much cheaper than for any type of solar heating system, wood heating equipment tax credits offer low and moderate income persons access to energy tax credits that they might otherwise not be able to gain.

- Many low income persons live in rural areas of the country and are in proximity to moderate priced or even free supplies of wood. Tax credits will help make equipment, the prime cost factor in this case, more affordable.

Increase ntilization of firewood may have additional sociai benefits

- A recent study by Brookhaven National Laboratory concluded that greater wood usage would benefit local economies and employment primarily by increased demand for cord wood.

- Wood heating offers a degree of independence and self reliance desired by many people in rural areas.

(9) There Are A Large Number of Policy Options and Alternatives That Need To Be Considered In The Decision of Whether Or Not To Include Residential Wood Burning Equipment in the Energy Tax Credit $\underline{\text { Program }}$

Level of incentive

- Opiion 0: No tax credit

- Option I: Renewable energy source tax credit ( 30 percent)

- Option II: Conservation tax credit (15 percent). 

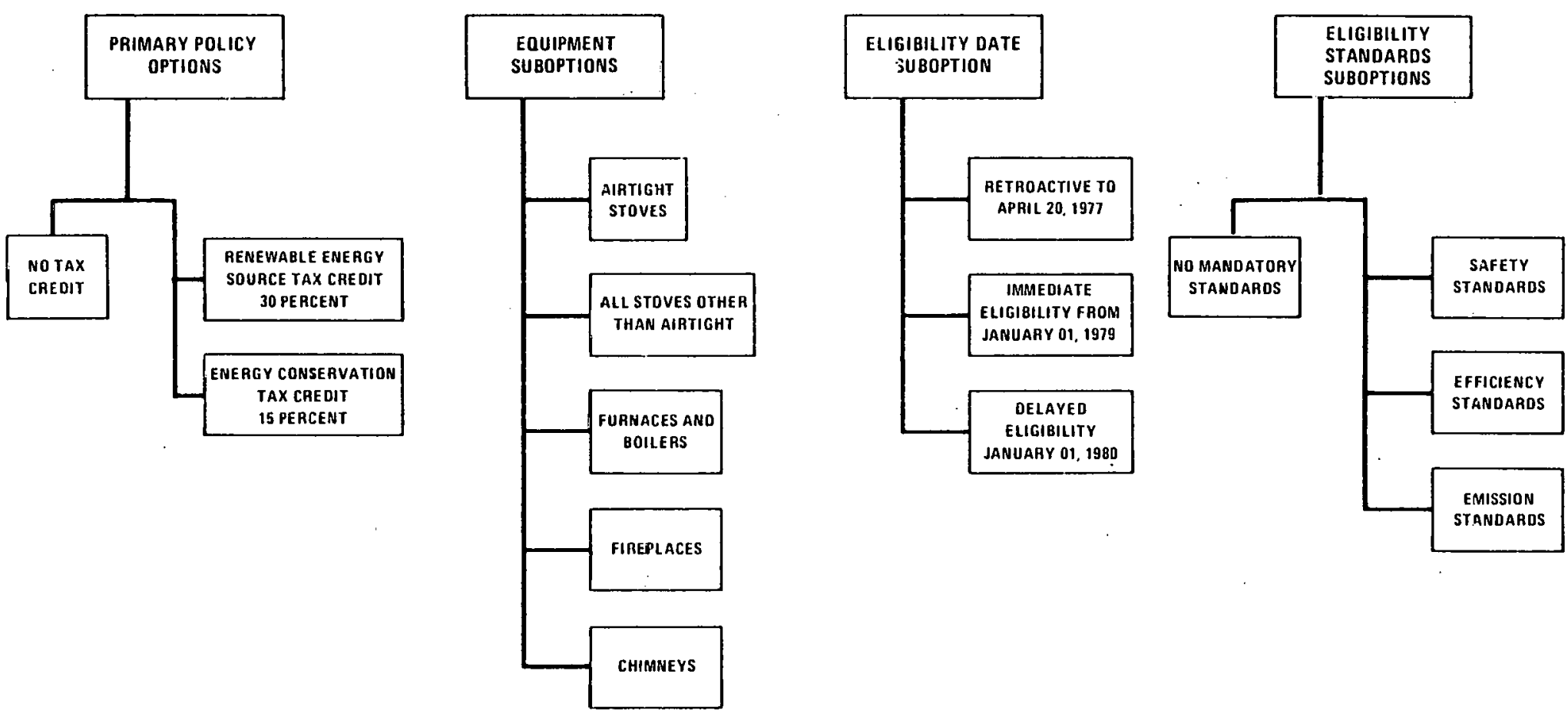
Equipment type

- Suboption A: Airtight stoves only

- Suboption B: All other stoves

- Suboption C: Furnaces and boilers

- Suboption D: Fireplaces

- Suboption E: Chimneys and auxiliary equipment.

Eligibility date

- Suboption 1: Retroactive to April 20, 1977

- Suboption 2: Immediate eligibility (i.e., January 1, 1979)

- Suboption 3: Delayed eligibility (i.e., January 1, 1980)

Safety, efficiency and emissions standards

- Suboption a: No mandatroy federal standards

- Suboption b: Safety standards

- Suboptior c: Efficiency standaxds

- Suboption d: Emissions standards.

The pros and cons of each of these options and combinations of options are presented in detail in Chapter $\mathrm{X}$.

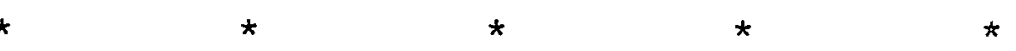

This Executive Summary has presented the key conclusions from a comprehensive review of issues influencing whether or not residential wood burning equipment should be included in the Energy Tax Act of 1978 tax credit program for individuals. For a complete discussion of the background information and analysis, refer to the body of this report which follows. 


\section{INTRODUCTION}

One of the key provisions of the National Energy Act (NEA) is a program of energy tax credits for individuals to encourage the purchase and installation of energy conservation components and alternate energy equipment for homes. At the time the NEA was passed by Congress, the list of qualifying energy conservation components included:

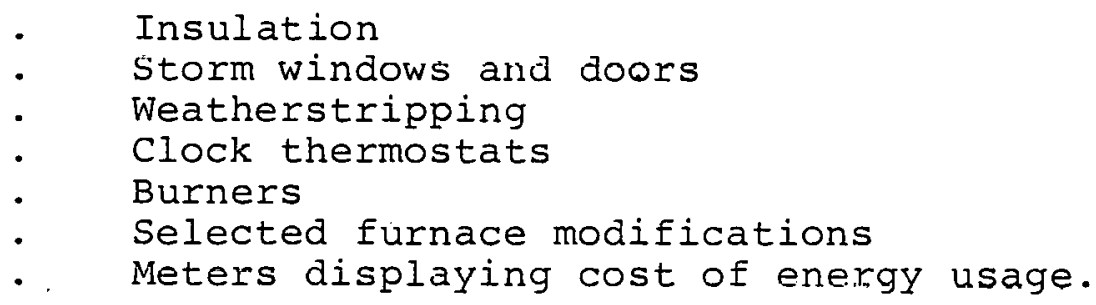

Although the final version of the NEA limited the qualifying components to those listed above, earlier versions contained a number of additional items including residential wood burning equipment. The effort to provide tax credits under the NEA for this type of equipment was formally initiated by Senator McIntyre on October 26, 1977 when he introduced Amendment 1521 to the Energy Tax Bill HR 5263. Despite strong support by some members of Congress for this Amendment, the final version of the bill emerged without tax credits for residential wood burning equipment. The Administration did state; however, that a study would be conducted of this provision and that if the merits warranted, this equipment could be added to the list of qualifying components by regulation. 1

As a result of an Administrative directive, the Department of Energy (DOE) was charged with performing a review and with developing recommendations for the inclusion or exclusion of wood burning equipment in the tax credit program.

1 Letter from Stuart Eizenstadt, Assistant to the President, to Senator McIntyre, October 14, 1978. 
This report, prepared for the Department of Energy by Booz, Allen \& Hamilton Inc., summarizes the results of a study of tax incentives for residential wood burning equipment. It presents an overview of the major issues affecting inclusion or exclusion of this equipment in the NEA ax redit rogram. The report was prepared as a quick response task within a six week period. Because of these time constraints, many simplifying assumptions had to be made in order to provide information in accordance with the decisionmaking schedule. The report is not meant to be considered as an exhaustive analysis of any particular issue area.

The objectives of this study were to:

- Analyze historical sales data for the wood burning equipment industry

- Estimate energy savings and tax revenue loss resulting from tax credits for wood burning equipment

- Examine the adequacy of existing equipment safety and performance standards

- Analyze environmental impacts and resource availability

- Estimate the effects of tax credits on balance of payments and on employment

- Determine the consumer economics of wood burning equipment.

In light of these objectives, the report is divided into eight chapters, each of which address a particular issue related to tax credit status. These chapters are:

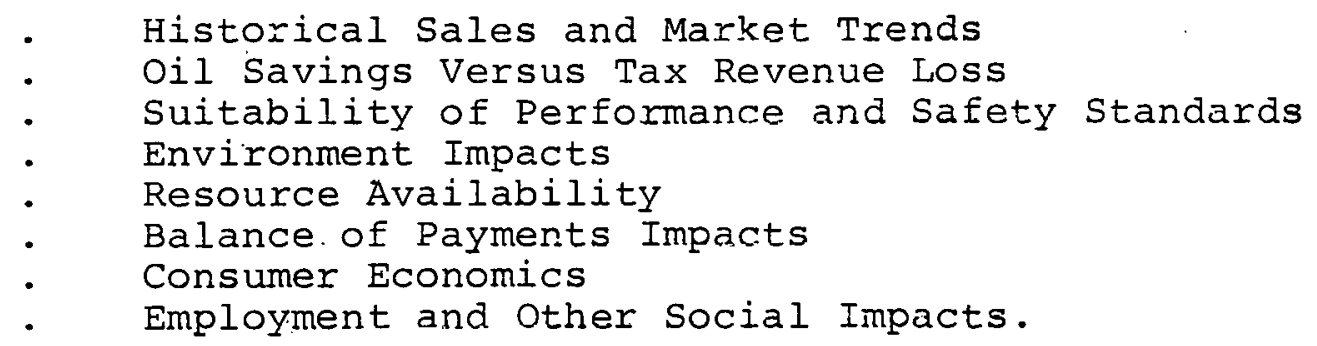

The report concludes with a chapter on DOE policy options. 
II. HISTORICAI SALES END MAREET TRENDE 


\section{HISTORICAL SALES AND MARKET TRENDS}

The wood heating equipment industry in the United states is over two centuries old. However, after world War I, when oil and gas displaced wood as the major source of heat for homes, the industry was left with only a few long-established firms. Since 1973 and the oil embargo, high prices for oil, gas and electricity have caused another reversal and sales of wood stoves have taken off. This in turn has led to a rapid increase in the number of manufacturers, distributors and retail dealers. It has also brought increasing attention to the stove and fireplace industry in terms of investor interest ${ }^{l}$ and in terms of government concern over various trade practices. $2,3,4$

Despite the attention being given to the industry, very little is actually know about it, primarily berause most of the manufacturers are privateiy held firms or are small divisions of large parent corporations. Furthermore, the major industry associations do not regularly collect sales data on the major categories of equipment sold.

For the purposes of this study a general perspective on the industry size and growth trends was gained primarily through telephone interviews with industry associations and several of the major manufacturers and distributors. This was supplemented with published data from the Department of Commerce and U.S. International Trade Commission. This chapter will present the findings from our research in four parts:

- Major types of equipment being sold

- Historical sales data

- Market size and potential

- Equipment price and performance assumptions.

1. "Look Who's Setting the World on Fire," Forbes, November 13, 1978.

2. U.S. International Trade Commission investigation on effects of imports on domestic cast iron stove industry, Juiy 1917.

3. Consumer Products Safety Commission investigation on mandatory safety labeling requirements for wood stoves; in process.

4. Federal Trade Commission preliminary investigation into sales and marketing practices in the wood and coal burning appliance industry; in process. 


\section{MAJOR TYPES OF EQUIPMENT BEING SOLD}

This section will briefly describe the three broad lines of equipment currently available on the market:

\section{Stoves}

Fireplaces

central heating equipment.

Exhibit II-l describes each type of equipment, their key features and typical construction materials. 5 summaries of key equipment features are given below.

(1): The Principal Type of Wood Heating Equipment Used in Homes Are Stoves

The styles of stoves vary widely from mailorder cast iron potbelly stoves costing less than $\$ 50$, to imported airtight radiant heaters capable of heating an entire house and costing $\$ 1,000$ or more.

- The most popular units for home heating are airtight, thermostatically controlled circulators and cast iron or plate steel radiant heaters. Generally these units cost between $\$ 300$ and $\$ 600$, plus installation.

Franklin stoves, kitchen cooking stoves and other traditional styles of heaters can also be used to supply home heating, but the performance and quality varies widely depending on price and decorative design features.

(2) Fireplaces Are Also Occasionally Used for Supplemental Heating in Homes

Fireplaces fall into three major categories:

- Free standing units costing $\$ 250$ to $\$ 50.0$

5 There are several. well-known publications that give detailed equipment descriptions: The Woodburners Encyclopedia, J. Shelton and A. Shapiro, Vermont Crossruads Press, 1976; The Complete Book of Heating With Wood, Gay, L., Gärden Way Publications, 1974. 
EXHIBIT II- 1

Major Types of Residential Wood Heating Equipment

\begin{tabular}{|c|c|c|}
\hline Equipment Category & Key Features & Construction Materials \\
\hline STOVES & • & \\
\hline - Radiant heaters & $\begin{array}{l}\text { Airtight construction; } \\
\text { high efficiency }\end{array}$ & $\begin{array}{l}\text { Mild steel plate or cast } \\
\text { iron; firebrick lining }\end{array}$ \\
\hline - Airtight circulators & $\begin{array}{l}\text { Rely on natural or } \\
\text { forced convection for } \\
\text { heat transfer; good } \\
\text { efficiency }\end{array}$ & $\begin{array}{l}\text { Sheet metal with fire- } \\
\text { brick lining }\end{array}$ \\
\hline - Franklin stoves & $\begin{array}{l}\text { Traditional style; may } \\
\text { be operated with doors } \\
\text { open or shut }\end{array}$ & Cast iron \\
\hline $\begin{array}{l}\text { Boxwood, potbelly, cooking } \\
\text { and parlor stoves }\end{array}$ & Traditional styling & Cast iron \\
\hline FIREPLAC[S & & \\
\hline - Free standing units & $\begin{array}{l}\text { Rectangular and cone } \\
\text { shaped styles; open } \\
\text { hearth }\end{array}$ & $\begin{array}{l}\text { Sheet steel; often } \\
\text { porcelain enameled }\end{array}$ \\
\hline $\begin{array}{l}\text { Zero clearance } \\
\text { prefabricated metal units }\end{array}$ & $\begin{array}{l}\text { Designed for slide in } \\
\text { installation; resembles } \\
\text { a masonry unit; some } \\
\text { units have heat recovery } \\
\text { ducis }\end{array}$ & Sheet steel \\
\hline - Masonry units & Custom built & Brick, stone, or concrete \\
\hline Accessories & $\begin{array}{l}\text { Grates, doors, screens, } \\
\text { tools }\end{array}$ & Varies \\
\hline CENTRAL HEATING EQUIPMENT & & \\
\hline - Boilers & $\begin{array}{l}\text { Resemble conventional } \\
\text { heating equipment ex- } \\
\text { cept have a larger fire } \\
\text { chamber for wood; usually } \\
\text { have oil or gas back-up } \\
\text { burner. }\end{array}$ & Normaliy cast iron \\
\hline - Furnaces & $\begin{array}{l}\text { Resemble conventiona? } \\
\text { heating equipment ex- } \\
\text { cept have a larger fire } \\
\text { chamber for wood }\end{array}$ & $\begin{array}{l}\text { Sheet metal; often } \\
\text { with cast iron fire } \\
\text { chamber }\end{array}$ \\
\hline - Add on units & $\begin{array}{l}\text { Convert a conventional } \\
\text { oil or gas furnace to } \\
\text { a dual fuel unit }\end{array}$ & Sheet metal \\
\hline
\end{tabular}


- Zero-clearance prefabricated metal fireplaces costing $\$ 400$ to $\$ 600$ plus installation of $\$ 500$ to $\$ 2,000$

- Conventional masonry firplaces costing at least $\$ 3,000$

The vast majority of fireplaces are used for aesthetic purposes or for emergency heating, but some are also used as the principal heat source as well.

(3) The Third Major Type of Wood Heating Equipment Are Central Systems

These systems include:

$$
\begin{array}{ll}
\text { - } & \text { Boilers } \\
\text { - } & \text { Furnaces } \\
\text { - Add-on units }
\end{array}
$$

- Often these units have oil or gas back-up burners that automatically switch on when the wood fire dies down

Prices for these units range from $\$ 1000$ to over $\$ 5000$, plus installation.

\section{HISTORICAL SALES DATA}

As mentioned earlier there is only limited data on actual sales of wood stoves, fireplaces and central heating equipment. Industry sources have estimated that 1978 sales of wood stoves were in the order of 750,000 units and that imports may have accounted for somewhere near 50 percent of this market. 6

Although a detailed survey of manufacturers was beyond the scope of this study, it was possible to assemble a preliminary picture of historical sales, based on:

Data published by the Department of Commerce ("Current Industrial Reports - Selected Heating Equipment" - No. MA34N)

6 Andrew Shapiro, President of the wood Energy Institute, quoted in Forbes, November 13, 1978. 
- Data assembled by the U.S. International Trade Commision (Tariff schedule classification items \#653.4900 and $\# 653.5025$ )

- Interviews with selected manufacturers

- Discussions with various industry representatives.

Exhibit II-2 summarizes the data available; the major findings from these data are discussed below.

(1) Total Wood Stove Sales Which Were Approximately 1.I Million Units for 1978 Have Shown a SevenFold Increase Since 1972

On a dollar basis, 1978 sales for stoves, chimneys, accessories and installation was approximately $\$ 1$ billion at the retail level.

- Aggregate growth was over 50 percent in 1974, 1975 and 1977 but was flat in 1973, 1976 and 1978 .

(2) Domestically Produced Stoves Have Shown Steady Overall Sales Increase, But Penetration Has Dropped in Some Market Segments

Domestic production accounts for about 65 percent of total sales. The total number of domestic units has risen from 140,000 in 1972 to an estimated 770,000 in 1978 .

Domestic production of cast iron stoves has dropped from a high of 230,000 units in 1975 to 120,000 units in 1978. This part of the domestic industry is having great difficulty competing with fabricated units and imports.

By far the strongest part of the domestic industry is fabricated stoves consisting of welded mild steel plate radiant heaters and thermostatically controlled circulator heaters.

Retail prices for domestically produced cast iron units range from $\$ 200$ to $\$ 400$; fabricated units typically are $\$ 300$ to $\$ 600$. 
EXHIBIT II-2

Historical Production and Shipment Data For Residential wood Burning Equipment (000's)

\begin{tabular}{|c|c|c|c|c|c|c|c|}
\hline $\begin{array}{l}\text { STOVES } \\
\text { Domestically Produced }\end{array}$ & 1972 & 1973 & 1974 & 1975 & 1976 & 1977 & 1978 \\
\hline $\begin{array}{l}\text { Cast Iron Units ( } 1) \\
\text { Fabricated Units }(1,3,4) \\
\text { Not Specified }\end{array}$ & $\begin{array}{r}110 \\
20 \\
10 \\
\end{array}$ & $\begin{array}{r}140 \\
40 \\
10 \\
\end{array}$ & $\begin{array}{r}160 \\
70 \\
10 \\
\end{array}$ & $\begin{array}{r}230 \\
230 \\
20 \\
\end{array}$ & $\begin{array}{r}120 \\
330 \\
20 \\
\end{array}$ & $\begin{array}{r}210 \\
530 \\
50 \\
\end{array}$ & $\begin{array}{r}120 \\
600 \\
50 \\
\end{array}$ \\
\hline Subtotal & 140 & 190 & 240 & 480 & 470 & 790 & 770 \\
\hline Imported Units & & & & & & & \\
\hline $\begin{array}{l}\text { Europe }(2,4) \\
\text { Asia }(2,4) \\
\text { Not Specified }\end{array}$ & $\begin{array}{l}* \\
* \\
*\end{array}$ & $\begin{array}{l}* \\
\star \\
*\end{array}$ & $\begin{array}{l}* \\
\star \\
\star\end{array}$ & $\begin{array}{r}30 \\
170 \\
80 \\
\end{array}$ & $\begin{array}{r}20 \\
150 \\
30 \\
\end{array}$ & $\begin{array}{r}40 \\
170 \\
30 \\
\end{array}$ & $\begin{array}{r}70 \\
300 \\
10 \\
\end{array}$ \\
\hline Subtotal & 20 & 20 & 80 & 280 & 200 & 240 & 380 \\
\hline TOTAL STOVES & 160 & 210 & 340 & 760 & 670 & 1030 & 1150 \\
\hline FURNACES AND BOILERS (1) & * & * & * & * & * & * & 50 \\
\hline FIREPLACES & & & & & & & \\
\hline Built-in Masonry & * & * & * & * & * & * & 650 \\
\hline $\begin{array}{l}\text { BujJ.t-in Zero Clearance } \\
\text { Free Standing }\end{array}$ & * & * & * & * & * & * & $\begin{array}{l}650 \\
150\end{array}$ \\
\hline
\end{tabular}

SOURCES :

1. Personal communications with manufacturers and their representatives

2. International Trade Commission

3. Department of Commerce

4. Booz, Allen \& Hamilton estimates

Data incomplete or not available 
(3) Imported Stove Units Are Approaching 35 Percent of the Total Unit Sales and Are Even More Dominant in Some Market Segments

- As shown in Exhibit II-2, the total number of imported units has dramatically risen from 20,000 in 1972 to 380,000 in 1978 .

- Most imported units are cast iron and because they often can be produced for less than their American counterparts, they account for about three-fourths of all cast iron units sold

- By far the largest portion of imported unit:s come from Asia, primarily Taiwan

- Imported units represent all price ranges. Most Asian units fall into the low to medium range (\$50-\$300 retail); European units are primarily in the higher price range (often $\$ 500$ and up).

(4) There Are No Official Statistics Available for Sales of Wood Fired Boilers or Furnaces, But Industry Sources Have Estimated That Sales for 1978 Were in the $50-65,000$ Unit Range

- This portion of the equipment industry has just begun to become active on a national scale over the last few years

- Both European and domestically produced products are marketed throughout the U.S.

(5) Industry Sources Estimated That Sales for A11 Types of Fireplaces Were Upwards of 1.5 Million Units in 1978

For this industry as well as the stove industry, there are no regularly gathered sales statistics

Sales have apparently doubled since 1972 with zero clearance units showing the largest increase. 
Of the total 1978 fireplace sales, approximately 1 million units were installed in new homes. The balance of sales were replacements and retrofits.

\section{MARKET SIZE AND POTENTIAL}

Although the Bureau of Census housing surveys do collect statistics on the number of homes using wood as a primary fuel, there is no count on the number of homes using wood stoves, fireplaces or furnaces for supplemental heating. Despite the lack of precise wood usage figures, it was possible to make order-of-magnitude estimates for the current and potential usage of residential wood heating equipment.

(1) Based on Historical Sales Data, Upwards of Five Million Wood Stoves and Wood Fired Central Heating Systems Have Been Sold Over the Last Ten Years

- Census data indicate that approximately one million homes used wood as a primary fuel in 1976 .

- Using sales statistics, upwards of three million homes may be using wood for a significant amount of supplemental heat

- At an average of four cords per house annual wood consumption, four million homes using wood fuel, and 2.5 barrels of oil per cord, the annual residential wood fuel usage in the U.S. is approximately 0.2 quads.

(2) A Preliminary Upper Iimit on the Potential for Residential Wood Usage Appears to be in the Range of Ten to Fifteen Mililon Homes

Out of a total of 70 milition year-round dwelling units, over 20 miliion are classified as in rural areas according to the Census of Housing 
- Of these 20 million rural dwelling units, a preliminary analysis indicated that between 10 and 15 million were in states with significant timber resources.

(3) Of the Total Potential Replacement Market for Oil and Gas Heating Equipment It Is Unlikely That Wood-Fired Boilers and Furnaces will Penetrate By More Than 10 Percent in the Next Seven Years

Current annual replacements of oil- and gasfired heating equipment is approximately 1.5 million units per year

- Sales of wood-fired boilers and furnaces were only about 50,000 units in 1978 and this was split between new and existing housing.

4. EQUIPMENT PRICE AND PERFORMANCE ASSUMPTIONS

For the purposes of performing the analyses in this report, it was necessary to establish characteristic price and performance levels for the equipment being considered for tax credit eligibility. Based on extensive discussions. with equipment manufacturers, dealers and installers average equipment prices, installed chimney costs, and equipment lifetimes were derived. Efficiencies were based on the latest test results from Auburn University for generic types of equipment.

These results are given in Exhibit II-3. 
III. EQUIVALENT OIL SAVINGS VERSUS TAX REVENUE LOSS 


\section{ECUIVALENT OIL SAVINGS VERSUS TAX REVENUE LOSS}

One of the major objectives of the Energy Tax Act of 1978 was to promote the purchase and installation of energy saving devices. In order to determine which devices should be eligible for tax credits, an assessment of the cost effectiveness of tiee incentive in each case is essential. This chapter summarizes an analysis of specific costs and benefits for one type of device under consideration, wood burning stoves and related wood heating equipment.

The tax credit options proposed for residential wood burning equipment can be evaluated using a number of benefit/ cost approaches. For this study, the measure of cost effectiveness for the tax credits was chosen to be the government cost per barrel of oil displaced. For this analysis, government cost is defined as the lost tax revenues resulting from tax credits claimed on individual income tax returns. Lost sales tax and other revenues from reduced oil sales and administrative costs of the tax credit program are not included in the government cost estimate. In addition, the government cost is not intended to reflect the cost to society. In fact, taxes are not social costs, but rather, income transfers and, therefore, not factors in social benefit/cost analyses. Taxes are costs to some individuals but equivalent benefits to others and, therefore, do not reflect costs to society as a whole.

The equivalent oil displacement is the expected energy conservation effect (converted to equivalent barrels of oil) resulting from increased equipment sales over that which would have occurred without the tax credits. Conventional fuels displaced will generally include oil, natural gas, and electricity. The level of displacement in each case will depend on the specific application, economics, and geographic region.

The definition of cost effectiveness used in this study, then, is fairly restrictive. Booz, Allen has not attempted to undertake a complete benefit/cost analysis. For example, private sector or consumer economics are not considered. The capital cost of the wuod burning cquipment to the consumer serves only as a basis for calculating tax revenue losses. Furthermore, the capital cost of wood burning equipment is only part of the total cost of wood energy. The annual wood fuel expenditure is much greater than the 
annualized wood burning equipment capital cost. A complete private benefit/cost or financial analysis would incorporate all of the capital, operating, fuel, and maintenance expenditures over the life of the equipment. Tax credits would essentially reduce life cycle costs by reducing annualized capital costs.

A complete public benefit/cost analysis would include, in addition to the private benefits and costs, social benefits and costs including employment, environmental, foreign trade, national security (embargo protection), and other impacts.

Such analyses require time and resources beyond those available for this task. The methodology chosen, however, is often used in energy policy analysis and was considered appropriate for this task. 1 Since wood burning equipment sales and tax revenue losses occur over time, dollar values are discounted to the present in this analysis to reflect the time value of money.

This chapter is divided into four parts:

- Discussion of the various policy options for wood burning equipment

- Projections of the sales of wood burning equipment with and without tax credits

- Methodology for estimating equivalent oil savings and tax revenue losses induced by the tax credit

Analysis of the equivalent oil savings, tax revenue losses, and cost effectiveness of the tax credit.

1 For example, see "President Carter's Energy Proposals: A Perspective," Congressional Budget Office Staff Working Paper, June 1977. 


\section{DOE POLICY OPTIONS}

There are several policy option combinations for wood burning equipment under consideration by DOE. The various policy options defined concern the level of the incentive, the type of equipment to which the incentive applies, the date of eligibility, and the safety, efficiency, and emissions standards for the equipment. The specific major

policy options regarding incentive levels may be summarized as follows:

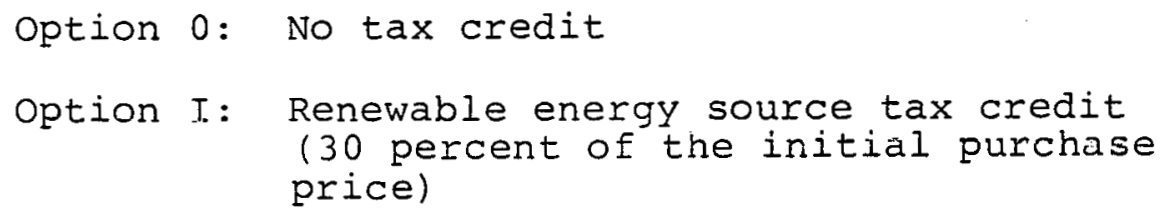

The major suboptions include the following:

Equipment type:

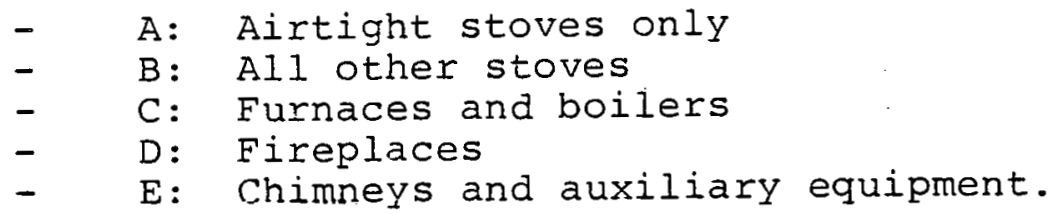

Eligibility date:

- 1: Retroactive to April 20, 1977

- 2: Immediate eligibility (i.e., January 1, $1979)$

- 3: Delayed eligibility (i.e., January 1, 1980).

Safety, efficiency and emissions standards:

$\begin{array}{ll}\text { - } & \text { a: No standards } \\ \text { - } & \text { b: Safety standards } \\ \text { - } & \text { c: Efficiency standards } \\ \text { - } & \text { d: Emissions standards. }\end{array}$

For the purpose of comparing policy options, the equivalent oil savings and tax revenue losses were computed for both renewable energy and conservation tax credits (options $I$ and II) and for each type of equipment (Suboptions $A$, 
$B, C, D$, and E). However, because of the large number of possible option combinations, immediate eligibility was assumed with no safety, efficiency, or emissions standards (Suboptions 2 and a).

In order to assess the impact of immediate eligibility requirements, separate comparison computations were made for both the retroactive and delayed eligibility suboptions (Suboptions 1 and 3). In both cases, the renewable energy source tax credit (Option I) was applied to airtight stoves and furnaces only (Suboptions $A+C$ ).

\section{SALES PROJECTIONS FOR WOOD BURNING EOUIPMENT}

In order to determine the equivalent oil savings and tax revenue losses resulting from a tax credit, wood burning equipment sales must be projected. At the time of this study, sales projections for residential wood burning stoves with and without tax credits were available from three sources:

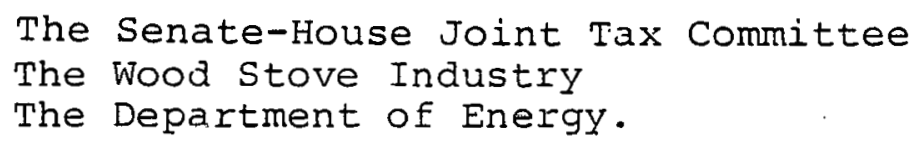

These projections are summarized in Exhibit III-l. In each case, the sales projections included airtight, high efficiency stoves only, under the assumption that less efficient stoves would not qualify for the tax credit.

(1) The Senate Projections Were Based on Data Developed By Wood Energy Institute (WEI)

The projections were developed in support of Senator McIntyre's Amendment (No. 1521) to the Energy Tax Bill (HiR 5263).

- Total sales with the tax credit from 1978 to 1985 were estimated at 3.9 million units. Incremental sales due to the tax credit during this period were 605,000 units.

- At the time of the amendment, a 20 percent tax credit was proposed for conservation devices; this percentage was assumed for projecting the potential increase in sales each year due to the tax credit. 
EXHIBIT III-1

Wood Stove Sales Projections

(Thousands)

\begin{tabular}{|c|c|c|c|c|c|c|c|c|c|}
\hline & \multicolumn{3}{|c|}{ SENATE PROJECTIONS } & \multicolumn{3}{|c|}{ INDUSTRY PROJECTIONS } & \multicolumn{3}{|c|}{ DOE/P\&E PROJECTIONS } \\
\hline & $\begin{array}{l}\text { WITHOUT } \\
\text { TAX CREDIT } \\
\text { (UNITS) }\end{array}$ & $\begin{array}{l}\text { WITH TAX } \\
\text { CREDIT' } \\
\text { (UNITS) }\end{array}$ & $\begin{array}{c}\text { INCREMENTAL } \\
\text { SALES } \\
\text { (UNITS) }\end{array}$ & $\begin{array}{c}\text { WITHOUT } \\
\text { TA.X CREDIT } \\
\text { (UNITS) }\end{array}$ & $\begin{array}{l}\text { WITH TAX } \\
\text { CREDIT }^{1} \\
\text { (UNITS) }\end{array}$ & $\begin{array}{c}\text { INCREMENTAL } \\
\text { SALES } \\
\text { (UNITS) }\end{array}$ & $\begin{array}{l}\text { WITHOUT } \\
\text { TAX CREDIT } \\
\text { (UNITS) }\end{array}$ & $\begin{array}{l}\text { WITH TAX } \\
\text { CREDIT }^{1} \\
\text { (UNITS) }\end{array}$ & $\begin{array}{c}\text { INCREMENTAL } \\
\text { SALES } \\
\text { (UNITS) }\end{array}$ \\
\hline 1978 & $N / A$ & 475 & - & 475 & 600 & 125 & 217 & 239 & 22 \\
\hline 1979 & $N / A$ & 550 & - & 550 & 800 & 250 & 243 & 267 & 24 \\
\hline 1980 & 560 & 590 & 30 & $5 \overline{0} 0$ & 860 & 300 & 270 & 297 & 27 \\
\hline 1981 & 500 & 550 & 50 & 500 & 800 & 300 & 297 & 327 & 30 \\
\hline 1982 & 350 & 425 & 75 & 450 & 700 & 250 & 323 & 355 & 32 \\
\hline 1983 & 300 & 400 & 100 & 400 & 600 & 200 & 358 & 394 & 36 \\
\hline 1984 & 300 & 450 & 150 & 400 & 600 & 200 & 376 & 414 & 38 \\
\hline 1985 & 275 & 475 & 200 & 400 & 600 & 200 & 403 & 443 & 40 \\
\hline $1978-1985$ & 2285 & 3915 & 605 & 3735 & 5560 & 1825 & 2487 & 2736 & 249 \\
\hline
\end{tabular}

1 ASSUMEd 20 PERCENT taX CREDIT 
EXHIBIT II-3

Wood Burning Equipment Prices and Performance Assumptions

\begin{tabular}{|c|c|c|c|c|c|c|}
\hline Type of Equipment & $\begin{array}{l}\text { Initial Equipment } \\
\text { Cost } 1\end{array}$ & $\begin{array}{l}\text { Installed } \\
\text { Chimney Cost }\end{array}$ & $\begin{array}{c}\text { Average } \\
\text { Annual } \\
\text { Efficiency }\end{array}$ & $\begin{array}{c}\text { Average Cords } \\
\text { of Wood } \\
\text { Consumed/Yr. }\end{array}$ & $\begin{array}{l}\text { Equivalent } \\
\text { Barrels of } \\
\text { 0il Saved/Yr. }\end{array}$ & $\begin{array}{l}\text { Equipment } \\
\text { Lifetime Yrs. }\end{array}$ \\
\hline Airtight stoves & $\$ 500$ & $\$ 300$ & $50 \%$ & 4 & 10 & 20 \\
\hline $\begin{array}{l}\text { All other types } \\
\text { of stoves }\end{array}$ & 300 & 300 & $25 \%$ & 4. & 5 & 15 \\
\hline Furnaces and boilers & 2000 & 500 & $50 \%$ & 8 & 20 & 20 \\
\hline Built-in fireplaces & 1000 & 1000 & $20_{m}^{a}$ & 1 & 1 & 20 \\
\hline
\end{tabular}

Notes:

1. Prices are based on manufacturer retail price lists, discussions with industry experts, and discussions with retail dealers.

2. Escalation rates of 6 percent per year (current dollars) were assumed for 1980 through 1985 for tax revenue loss calculations in Chapter III.

3. Heating value of wood fuel assumed to be $20 \mathrm{million}$ Btu/cord.

4. Equivalent barrels of oil saved based on 140,000 Btu/gal. and 70 percent oil burner efficiency.

5. Example calculation of oil savings: 4 cords/house $x 20 \mathrm{million}$ Btu/cord $\mathbf{x} 50 \%$ wood combustion efficiency $\div$ $140,000 \mathrm{Btu} / \mathrm{gal} . \div 70 \%$ oil burner efficiency $\div 42 \mathrm{gal} / \mathrm{bbl}=10 \mathrm{bbl} / \mathrm{house}$.

6. Average cord usage derived from published surveys of cord wood consumption in three New England states. Cord wood usage is believed to be fairly similar in other regions but the stove or furnace woulc supply a higher portion of a home's heating requirements in warmer areas. 
- Equipment prices were based on the installed cost of a typical wood stove (including a chimney). The 1978 price was $\$ 655$ which was assumed by WEI to escalate at an increasing rate through 1981, then at a decreasing rate through 1985. The annual percentage increase in prices varied from a low of 6 percent to a high of 18 percent.

(2) The Wood Stove Industry Projections Were Developed By John Lynn, President of Fisher Stoves

- The projections referred to high quality residential airtight wood stoves.

- Total sales with the tax credit from 1978 to 1985 were projected to be 5.6 million units with incremental sales of 1.8 million units

- A 20 percent tax credit in effect through 1985 was assumed for projecting the potential increase in sales each year due to the tax credit.

- The installed cost of a high quality airtight wood stove was estimated at $\$ 800$ (including a metal chimney) and was assumed to escalate at 6 percent annually.

(3) The Department of Energy (DOE) Projections Were Developed By the office of Policy and Evaluation (P\&E)

Total sales with the tax credit for the eight-year period were estimated at $2.7 \mathrm{mil-}$ lion units; incremental sales were 219,000 units.
A 20 percent tax credit in effect through 1985 was assumed.

An assumed price elasticity of demand of 0.5 was the basis for estimating the potential increase in sales due to the tax credit.

- The cost per wood stove was assumed to be $\$ 424$ in 1978 and was assumed by DOE to escalate at 6 percent annually. This cost per stove excluded chimneys which were defined as ineligible. 
(4) The Potential Increase in Sales Each Year Due to the Tax Credit Varies Significantly Among the Three Projections

Sales projections with and without the tax credit are summarized in Exhibit III-l. Incremental sales vary among these estimates as a result of both the base sales projections and the presumed effectiveness of the credit. A discussion of these factors is given below.

The base sales projections vary among the three projections

- The Senate annual base sales estimates (i.e., without tax credits) decrease from 560,000 units in 1980 to 275,000 units in 1985.

- The industry base sales estimates without the tax credit show an increase in annual sales to 560,000 in 1980 declining to 400,000 from 1983 through 1985 .

- The DOE base sales estimates presume an increase of more than 25,000 units annually from a low of 217,000 units in 1978 to a high of 403,000 units in 1985 without the tax credit.

The DOE estimates assumed a price elasticity of demand of 0.5 In this case, a 20 percent tax credit causes an increase in the number of units sold of 10 percent.

The industry estimates indicate a much greater degree of responsiveness to the tax credit. A $20^{\circ}$ percent tax credit is presumed to cause an average increase in the number of units sold of nearly 50 percent. This implies a price elasticity of demand of 2.5. Elasticity assumptions were not stated explicitly, however.

The Senate estimates imply an increasing price elasticity of demand over time. In 1980, for example, the 20 percent tax credit causes a 5 percent increase in unit sales. By 1985, the incremental unit sales have risen to more than 70 percent of the sales 
estimate without the tax credit. This implies a price elasticity of demand in 1980 of 0.25 increasing to 3.5 by 1985 . Again, elasticity assumptions were not stated explicitly.

- The direct estimation of price elastiaities of demand for wood stoves requires far more detailed historical sales and price data than is currently available. Demand studies for other durable goods, however, indicate a range between 0.5 and 1.0 for short-run elasticities and well over 2.0 in some cases for long-run elasticities. ${ }^{2}$ By comparison, nondurable goods show much less sensitivity to price in both the short- and the long-run.

- In addition, however, aggregate demand for energy studies estimate slightly lower elasticity factors. These studies indicate shortrun elasticities in the range of 0.3 to 0.5 and long-run elasticities between 0.7 to 1.1 .3 However, since the aggregate demand for energy is presumably less responsive to price than the demand for specific fuels, both long-run and short-run elasticity factors for specific fuels are expected to be somewhat higher than the aggregate estimates. In other words, price has a greater impact on the demand for oil, natural gas, or fuelwood-especially in the case of home heating - than it has on the demand for energy in general. Consequently, the three estimates presented provide a wide but reasonable range of estimates for the effect of a tax credit on unit sales.

(5) Booz, Allen Sales Projections Were Made For Wood Burning Stoves and Other Related Heating Equipment

Previous studies of the effect of tax credits on wood burning equipment sales considered only airtight,

2. For example, see Houthakker and Taylor, Consumer Demand in the United States, 1970.

3 Pindyck, Robert S., "The Characteristics of the Demand for Energy," unpublished paper, May 1978. 
high efficiency, wood burning stoves. In this analysis various kinds of wood burning equipment are examined. Base sales projections for each type of wood burning equipment are given in Exhibit III-2.

The following methodology was employed to estimate base and incremental sales through 1985:

Historical sales data were obtained for airtight stoves, all other stoves, furnaces, and fireplaces.

Based on extrapolations of historical sales trends and on discussions with industry associations and manufacturers, base sales projections were made through 1985 (i.e. sales without tax credits).

- A price elasticity of demand of 1.0 was assumed in order to calculate the additional sales induced by the tax credit.

Based on the previous studies of wood stove tax credits, related demand studies for durable goods and aggregate energy, and conversations with industry representatives, a unitary elasticity of demand was considered a reasonable estimate.

The demand elasticity factor was assumed to apply to the stove, furnace, or fireplace unit only. The eligibility of tax credits for chimney installations was assumed to impact tax revenue losses but not unit sales. In effect, a demand elasticity factor for chimneys of zero was assumed.

In some cases-perhaps 25 to 50 percent-additional capital expenditures for chimney installations may be required. Since a chimney can increase the capital cost of the equipment by 25 to 50 percent, the eligibility of chimneys for tax credits may substantially reduce life cycle costs resulting in increased sales. However, the degree of responsiveness is uncertain and a complete life cycle cost or benefit/cost analysis is beyond the scope of this report.

Although additional sales induced by the tax credit are assumed to cease after 1985, further sales may continue as an indirect result of the tax credit 
EXHIBIT III-2

BA\&H Base Sales Projections Through 1985 For Residential Wood Burning Equipment (Thousands of Units)

\begin{tabular}{|c|c|c|c|c|c|}
\hline Year & $\begin{array}{l}\text { Efficient } \\
\text { Stoves }\end{array}$ & $\begin{array}{l}\text { All } \\
\text { Other } \\
\text { Stoves }\end{array}$ & Furriaces & Fireplaces & $\begin{array}{l}\text { Total Resid. } \\
\text { Wood Burn } \\
\text { Equipment }\end{array}$ \\
\hline $\begin{array}{l}1979 \\
1980 \\
1981 \\
1982 \\
1983 \\
1984 \\
1985\end{array}$ & $\begin{array}{l}600 \\
600 \\
600 \\
600 \\
700 \\
700 \\
700 \\
\end{array}$ & $\begin{array}{l}600 \\
600 \\
600 \\
600 \\
600 \\
500 \\
500 \\
\end{array}$ & $\begin{array}{r}50 \\
50 \\
100 \\
100 \\
100 \\
150 \\
150 \\
\end{array}$ & $\begin{array}{l}700 \\
700 \\
700 \\
700 \\
700 \\
700 \\
700 \\
\end{array}$ & $\begin{array}{l}1,950 \\
1,950 \\
2,000 \\
2,000 \\
2,000 \\
2,050 \\
2,050 \\
\end{array}$ \\
\hline $\begin{array}{l}\text { TOTAL } \\
\text { Less units in } \\
\text { vacation homes }\end{array}$ & $\begin{array}{l}4,500 \\
500(10 \%)\end{array}$ & $600(14 \%)$ & 700 & $\begin{array}{l}4,900 \\
1,000(20 \%)\end{array}$ & $\begin{array}{r}14,100 \\
2,100 \\
\end{array}$ \\
\hline $\begin{array}{l}\text { Net units in } \\
\text { primary homes }\end{array}$ & 4,000 & 3,400 & 700 & 3,900 & 12,000 \\
\hline
\end{tabular}

Notes:

1 Sales projections are for wood burning equipment installed in privately owned, single family residences.

2 Sales trends are based on extrapolations of historical sales trends and on discussions with industry associations and manufacturers.

3 Since there are no government statistics on the amount of wood burning equipment installed in vacation homes, order-of-magnitude estimates for this were made based on discussions with several large wood stove and fireplace manufacturers. 
through a demonstration effect. Consequently, increased sales due to the tax credit may be even greater.

- Projections were made for both the 15 percent conservation and the 30 percent renewable energy source tax credit for each type of wood burning equipment.

3. METHODOLOGY FOR COMPUTING EQUIVALENT OIL SAVINGS AND TAX REVENUE LOSSES FOR WOOD BURNING EQUIPMENT

The types of wood burning and related equipment considered in this analysis include the following:

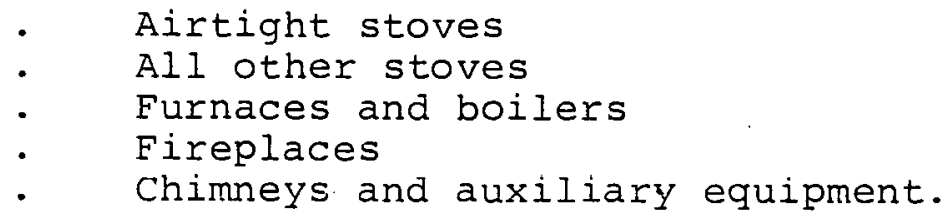

For each equipment type, equivalent oil savings for the incremental sales of wood burning equipment due to the tax credits were calculated over their expected life. Consequently, some positive savings will occur through 2005. Since the tax credit is in effect only through 1985, tax revenue losses were computed through 1985.

(1) Several Assumptions Were Necessary to Estimate Equivalent oil Savings and Tax Revenue Losses

Airtight stoves with an average cost of $\$ 500$ are assumed to have an expected life of 20 years and displace $10 \mathrm{bbl}$. of oil annually 4

- All other stoves with an average cost of only $\$ 300$ are assumed to have a 15-year expected life and displace $5 \mathrm{bbl}$. of oil annually

Furnaces cost approximately $\$ 2,000$, last 20 years, and save $20 \mathrm{bbl}$. of oil annually

4 The assumed oil savings per unit is based on an average of 20 million Btu's per cord of firewood, and a combustion efficiency of 50 percent for the wood burning equipment. 
- Fireplaces have a 20-year expected Iife, displace only $1 \mathrm{bbl}$. of oil annually and cost $\$ 1,000$ on average

The installed chimney cost for airtight and all other wood stoves is $\$ 300$. For furnaces, the cost is $\$ 500$, and for fireplaces $\$ 1,000$

Oil prices were assumed to be $\$ 14$ per bbl. in 1979 escalating at 10 percent annually

A discount rate of 10 percent was used in accordance with the office of Management and Budget $(O M B)$ policy.

Wood burning equipment prices, combustion efficiencies, fuel usage, and unit oil savings are summarized in Exhibit II-3. (Chapter II)

(2) Based On These Assumptions, Equivalent Oil Savings Through 2004 and Tax Revenue Losses Through 1985 Were Calculated

Estimates were made for each equipment type shown above assuming both a 15 percent conservation tax credit and a 30 percent renewable energy source tax credit.

The incremental sales induced by the tax credit were used to compute savings in bbl. oil equivalent per year over a 15 to 20 year period depending on the type of equipment.

Tax revenue losses were calculated at 15 and 30 percent of the total dollar sales (i.e., base plus incremental) through 1985 for the conservation and renewable energy source tax credits, respectively. An example calculation of the annual oil savings and tax revenue loss are given in Exhibit III-3.

The total tax or cumulative revenue losses, equivalent oil displacement, and tax revenue loss per.bbl. are presented in Exhibit III-4.

- Equipment suboptions were prioritized on the basis of their contribution to equivalent oil savings, then added cumulatively in Exhibit III-5 to obtain cumulative estimates of the combined equipment suboptions. Tax revenue losses per bbl. of oil, then, are 
EXHIBIT III-3

Example Calculation of Annual Equivalent Oil Savings and Tax Revenue Loss

-For Airtight Wood Stoves Only, 15̣\% 'Tax Credit Level, 1979 Eligibility-

\begin{tabular}{|c|c|c|c|c|c|c|c|c|c|c|c|c|c|}
\hline \multirow[b]{2}{*}{ Year } & \multicolumn{6}{|c|}{ Equivalent 0il Savings } & \multicolumn{7}{|c|}{ Tax Revenue Loss } \\
\hline & $\begin{array}{c}\text { Units in } \\
\text { Place in } \\
\text { Primary } \times \\
\text { Homes } \\
\text { (Millions) } \\
\end{array}$ & $\begin{array}{c}\text { Increniental } \\
\text { Delland } \\
\text { Factor }\end{array}$ & $\begin{array}{c}\text { Annual } \\
\text { Savings } \\
\times \quad \text { Per } \\
\text { Stove } \\
(\text { bbl/Yr) } \\
\end{array}$ & $=\begin{array}{c}\text { Annual } \\
\text { Savings } \\
\text { iMillion } \\
\text { bbl) }\end{array}$ & $\div \frac{\text { Days }}{Y_{r}}=$ & 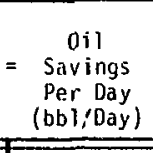 & $\begin{array}{l}\text { Annual Base } \\
\text { Sales to } \\
\text { Primary Homes } \\
\text { (Millions } \\
\text { of Units) } \\
\end{array}$ & $\begin{array}{r}\text { Tax Credit } \\
\times \quad \text { Hultiplier } \\
\end{array}$ & $\begin{array}{c}\text { Total Annual } \\
\text { Sales With } \\
=\text { Tax Credit } \\
\text { (liillions } \\
\text { of Units) } \\
\end{array}$ & $\begin{array}{c}1979 \\
\times \text { Price/ } \\
\text { Uni } \\
(\$) \\
\end{array}$ & $\begin{array}{c}\text { Price } \\
\text { Multiplier } \\
\times \quad(06 \% \\
\text { Increase/ } \\
\text { Yr) } \\
\end{array}$ & $\begin{array}{c}\text { Tax } \\
\times \text { Credit } \\
\text { Level } \\
(\%)\end{array}$ & $=\begin{array}{c}\text { Tax Revenue } \\
\text { Loss } \\
\begin{array}{c}\text { Undiscounted } \\
(\$ \text { Million })\end{array} \\
\end{array}$ \\
\hline $\begin{array}{l}1979 \\
1980 \\
1981 \\
1982 \\
1983 \\
1984 \\
1985 \\
\mid \\
1999 \\
2000 \\
2001 \\
2002 \\
2003 \\
2004\end{array}$ & $\begin{array}{l}0.5 \\
1.0 \\
1.5 \\
2.0 \\
2.6 \\
3.3 \\
4.0 \\
1 \\
3.5 \\
3.0 \\
2.5 \\
2.0 \\
1.4 \\
0.7\end{array}$ & $\left.\right|^{0.15}$ & $\left.\right|^{10}$ & $\begin{array}{l}.7 \\
1.5 \\
2.2 \\
3.0 \\
3.9 \\
4.9 \\
6.0 \\
\downarrow \\
5.3 \\
4.5 \\
3.8 \\
3.0 \\
2.1 \\
1.1\end{array}$ & $\int^{365}$ & $\begin{array}{c}2,100 \\
4,100 \\
6,200 \\
8,200 \\
10,700 \\
13,600 \\
16,400 \\
\\
14,400 \\
12,300 \\
10,300 \\
8,200 \\
5,800 \\
2,900\end{array}$ & $\begin{array}{l}0.5 \\
0.5 \\
0.5 \\
0.5 \\
0.6 \\
0.7 \\
0.7 \\
\text { N/A } \\
1 \\
1\end{array}$ & $i^{1.15}$ & $\begin{array}{l}.575 \\
.575 \\
.575 \\
.575 \\
.690 \\
.805 \\
.805\end{array}$ & $\left.\right|^{500}$ & $\begin{array}{l}1.0 \\
1.06 \\
1.124 \\
1.191 \\
1.262 \\
1.338 \\
1.419\end{array}$ & $\left.\right|^{15 \%}$ & $\begin{array}{l}43 \\
46 \\
48 \\
51 \\
64 \\
80 \\
85\end{array}$ \\
\hline TOTAL & - & - & - & 120 & - & - & 4.0 & - & 4.6 & - & - & - & 417 \\
\hline
\end{tabular}

NareS: 1. See Exhibit III-5 footnotes for the assunptions used to calculace the value ill thi.s crhibitit.

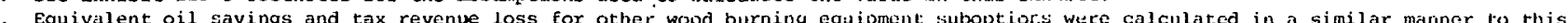

Assunptions for units sold, incremental demand factor, annual savings per stove, equi,pment lifeti.ne, uni.t price, and tax crełit rate were

varied as discussed in the text. 
EXHIBIT III-4

Oil Savings Versus Tax Revenue Loss For Wood Burning Equipment

\begin{tabular}{|c|c|c|c|c|c|}
\hline $\begin{array}{l}\text { Equipment } \\
\text { Suboption }\end{array}$ & $\begin{array}{c}\text { Tax } \\
\text { Credit } \\
\text { Level } \\
\text { (percent) }\end{array}$ & $\begin{array}{l}\text { Equivalent 0il } \\
\text { Savings for the } \\
\text { Incremental Sales } \\
\text { Through } 2004 \\
\text { (million bbl.) }\end{array}$ & $\begin{array}{c}\text { Tax Revenue } \\
\text { Loss } \\
1979-1985 \\
(\$ \text { million })\end{array}$ & $\begin{array}{l}\text { Present Value } \\
\text { of Tax } \\
\text { Revenue Loss } \\
1979-1985 \\
\text { (\$ million) }\end{array}$ & $\begin{array}{c}\text { Present Value } \\
\text { of Tax Revenue } \\
\text { Loss Per bbl. } \\
0 \text { il Saved } \\
(\$)\end{array}$ \\
\hline $\begin{array}{l}\text { Airtight } \\
\text { Stoves }\end{array}$ & $\begin{array}{l}30 \\
15\end{array}$ & $\begin{array}{l}240 \\
120\end{array}$ & $\begin{array}{l}944 \\
417\end{array}$ & $\begin{array}{l}689 \\
304\end{array}$ & $\begin{array}{l}2.87 \\
2.53\end{array}$ \\
\hline Furnaces & $\begin{array}{l}30 \\
15\end{array}$ & $\begin{array}{l}80 \\
40\end{array}$ & $\begin{array}{l}650 \\
290\end{array}$ & $\begin{array}{l}477 \\
212\end{array}$ & $\begin{array}{l}5.96 \\
5.30\end{array}$ \\
\hline $\begin{array}{l}\text { A11 0ther } \\
\text { Stoves }\end{array}$ & $\begin{array}{l}30 \\
15\end{array}$ & $\begin{array}{l}75 \\
38\end{array}$ & $\begin{array}{l}479 \\
212\end{array}$ & $\begin{array}{l}350 \\
155\end{array}$ & $\begin{array}{l}4.67 \\
4.08\end{array}$ \\
\hline Fireplaces & $\begin{array}{l}30 \\
15\end{array}$ & $\begin{array}{l}24 \\
12\end{array}$ & $\begin{array}{r}1851 \\
817\end{array}$ & $\begin{array}{r}1351 \\
596\end{array}$ & $\begin{array}{l}56.29 \\
49.67\end{array}$ \\
\hline
\end{tabular}

NOTE: See Exhibit III-5 Footnotes for the assumptions used to calculate the values in this Exhibit. 
EXHIBIT III- 5

Oil Sàvings Versus Tax Revenue Loss For Selected DoE Policy Option Combinations

\begin{tabular}{|c|c|c|c|c|c|c|c|c|}
\hline CODE & POL ICY OPTIOHS & $\begin{array}{r}\text { BASE } \\
\text { SALES } \\
\text { 1979-1985 } \\
\text { MIL. UNIITS } \\
\end{array}$ & $\begin{array}{l}\text { IHCREMEMTAL } \\
\text { SRILS } \\
\text { MLL. UNIIIS }\end{array}$ & 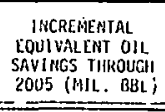 & $\begin{array}{r}\text { TOTAL } \\
\text { SALES } \\
\text { MEL. UIIISS } \\
\end{array}$ & $\begin{array}{l}\text { TAXX REVEFUEE } \\
\text { LoSS } \\
\text { 1979-1085(SHALL) } \\
\end{array}$ & 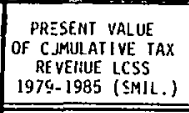 & 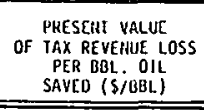 \\
\hline I.A.2.a & $\begin{array}{l}\text { SOLAK TAX CREDIT FOR AIRIIGHI } \\
\text { STOVES OHLY }\end{array}$ & 4.0 & 1.2 & 290 & 5.2 & 944 & 689 & 2.87 \\
\hline 1.A+C.2.a & $\begin{array}{l}\text { SOLAR IRX CREDIT FOR AIRTICHT } \\
\text { STOVES ALU FURNACES }\end{array}$ & 4.7 & 1.4 & 320 & ก.1 & 1,597 & 1,166 & 3.64 \\
\hline $1 . A+B+C .2 . a$ & $\begin{array}{l}\text { SOLAR TAX CREOII FOR ALL STOVES } \\
\text { AIIO FURIACCSS }\end{array}$ & 8.1 & 2.4 & 395 & 10.5 & 2.076 & 1,516 & 3.84 \\
\hline I. $. A_{1} B+C+D .2 . \mathrm{B}$ & $\begin{array}{l}\text { SOLAR TAX CMEOIY FOR ALL STOUES, } \\
\text { FURIACES, GND FIREPLACES }\end{array}$ & 12.0 & 1.6 & 419 & 15.6 & $3,9.7$ & 2.867 & 6.84 \\
\hline $1 . A+B+C+0+E .2 . a$ & $\begin{array}{l}\text { SOIARR TTX CREEIT FOR ALL STOVES } \\
\text { FURARCES, THREPLACES, AII CHIWIEYS }\end{array}$ & 12.0 & 3.6 & 419 & 15.6 & 6,987 & 5.101 & 12.17 \\
\hline It.A.2. A & 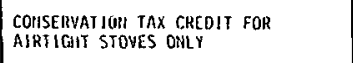 & 4.0 & 0.6 & 120 & 4.6 & 917 & 304 & 2.53 \\
\hline $11 . A+C .2 .0$ & $\begin{array}{l}\text { COASERVAT ION TAX CREDIT FOR } \\
\text { AIRTIULAT SOOVES AND FURRIACES }\end{array}$ & 4.7 & 0.7 & 160 & 5.4 & $70 \%$ & 516 & 3.23 \\
\hline$\| 1 \cdot A+B+C .2 . a$ & $\begin{array}{l}\text { CONSERYAT IOH TAX CREUIT FOR ALL } \\
\text { STOVES AIID FURIACES }\end{array}$ & 8.1 & 1.2 & 198 & 9.3 & 919 & 671 & 3.39 \\
\hline $11 . A+B+C+D .2 . A^{*}$ & $\begin{array}{l}\text { COISERVAT IOH TAX CREDIT FOR ALL } \\
\text { STOVES, FURIICES. AHU FIREPLACES }\end{array}$ & 12.0 & 1.8 & 210 & 13.8 & 1,736 & 1.267 & 6.03 \\
\hline$(1, A+B+C+B) C, 2, a$ & 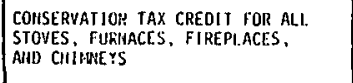 & 12.0 & 1.8 & 210 & 13.8 & 3.370 & 2,460 & 11.71 \\
\hline 1.A+C.1.a & 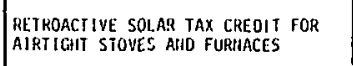 & 5.5 & 1.4 & 320 & 6.9 & 1.797 & 1.312 & 4.10 \\
\hline \multirow[t]{2}{*}{ 1.A+C.3.0 } & 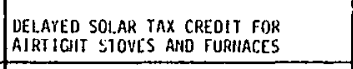 & 4.0 & 1.2 & 280 & 5.2 & 1.434 & 1,047 & 3.74 \\
\hline & $\begin{array}{l}\text { IIISULATION TAX CREDIT COMPARISON } \\
\text { SOL.AR UOME IAX C.REOIT COHPARISON }\end{array}$ & $\begin{array}{r}16.0 \\
0.5\end{array}$ & $\begin{array}{l}7.8 \\
0.3\end{array}$ & 890 & $\begin{array}{r}23.8 \\
0.8\end{array}$ & $\begin{array}{r}2.804 \\
379\end{array}$ & 2,100 & 2.42 \\
\hline
\end{tabular}

roounotes:

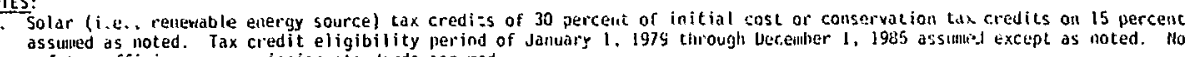

safety, efficiency. or enission standards as sumed.

2. Assumed equipment prices for 1979 are:

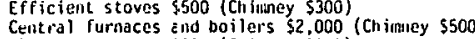

All other stoves $\$ 300$ (Chinmer $\$ 300$ )

3. Equipment prices assunled to escalate at 6 percent per year.
4. Increnuntol sales increases based on denand elasticity factior of 1.0 .

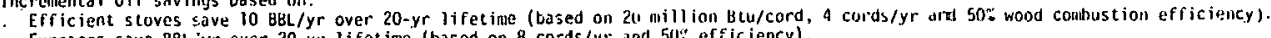

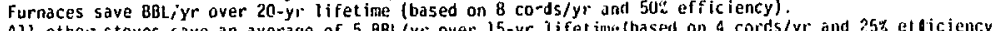

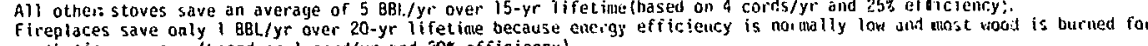
desthetic purvoses (based on 1 cord/yr and $20 \%$ efficiensy).

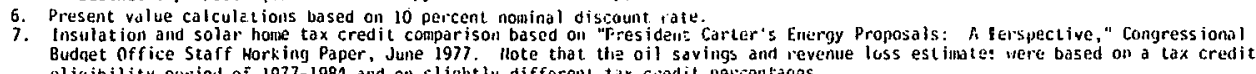

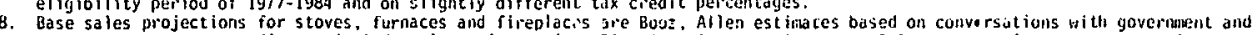

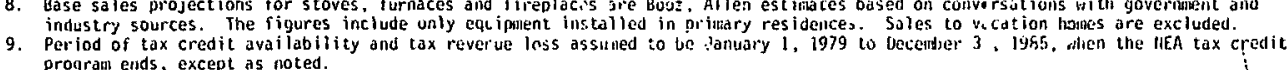


weighted averages for the policy option combinations.

Retroactive and delayed eligibility were compared to the immediate eligibility suboption assumed throughout the analysis by increasing or decreasing the equivalent oil savings and tax revenue losses in accordance with historical and projected sales estimațes.

- Equivalent oil savings and tax revenue losses due to insulation and solar home tax credits were developed in the Congressional Budget office (CBO) study. 5 They àre also presented in Exhibit III-5 for the purpose of comparison.

Exhibit III-5 is essentially built from Exhibit III-4. The calculation procedures for the values in both exhibits are best understood through sample calculations:

\begin{abstract}
For furnaces, a 30 percent tax credit results in a 30 percent increase in sales based on the unitary elasticity assumption. Since base sales from 1979 through 1985 are 700,000 units, additional sales amount to 30 percent of 700,000 or 210,000 units. In Exhibit III-5, the 700,000 units are added to the base sales for airtight stoves (column 1) to obtain the 4.7 million unit total for the airtight stoves and furnaces policy option combination. Similarly, the additional or incremental sales for furnaces are added to those for airtight stoves to obtain the 1.4 million unit total in row 2 of column 2 .

Over a 20-year life each furnace will displace $20 \mathrm{bbl}$ per year for a total of $400 \mathrm{bbl}$. The 210,000 additional units, then, will displace approximately 80 million bbl over their lifetime. In Exhibit III-4,
\end{abstract}

5 "President Carter's Energy Proposals: A Perspective," Congressional Budeet office Staff Working Paper, June 1977. 
this is shown in column 2 for the 30 percent tax credit on furnaces (row 3). In Exhibit III-5, the 80 million bbl is added to the 240 million bbl for airtight stoves to obtain the 320 million bbl for the airtight stove and furnace combination (column 3).

Base sales without the tax credit plus incremental sales due to the tax credit are shown in column 4 of Exhibit III-5 as total sales.

Tax revenue losses for furnaces require the valuation of annual unit sales based on an assumed price of $\$ 2,000$ escalated at 6 percent annually. The sum of the annual total dollar sales through 1985 are then multiplied by the 30 percent tax credit to obtain the $\$ 650$ million tax revenue loss for furnaces in column 3 of Exhibit III-4. In Exhibit III-5, the tax revenue loss for furnaces is added to that for airtight stoves to obtain the $\$ 1,597$ million total for the airtight stove and furnace policy option combination (column 5).

The present value of the tax revenue loss for furnaces and the airtight stoves and furnaces combination is computed in column 4 of Exhibit III- 4 and column 6 of Exhibit III-5, respectively.

The present value of the tax revenue loss per bbl oil saved for furnaces is simply the ratio of column 4 to column 2 in Exhibit III-4 (column 5). In Exhibit III-5, the corresponding present value for the airtight stove and furnace combination (column 7) is the ratio of column 6 to column 3. In this case, the government cost per bbl is a weighted average value for the policy option combination. 
4. ANALYSIS OF EQUIVALENT OIL SAVINGS AND TAX REVENUE LOSSES

The results of the analysis in terms of incremental equipment sales, incremental oil savings, tax revenue loss, and equivalent government cost per barrel are tabulated in Exhibit III-5. Based on this data, a number of conclusions can be drawn.

(1) The Equivalent Oil Savings That Can Be Expected From Wood Burning Equipment Tax Credits Depend On the Level of the Incentive and the Equipment Suboptions Eligible

- If all equipment suboptions are assumed eligible for the tax credit, nearly 420 million bbl oil could be displaced by 2005 . This translates into 43,000 bbl per day over the 27-year period.

- It should be noted that most of the incremental oil savings is attributable to high efficiency, airtight stoves under both the 15 and 30 percent tax credit assumptions. For example, assuming a 30 percent tax credit, airtight stoves contribute 240 million bbl; furnaces 80 million bil; all other stoves $75 \mathrm{million}$ bbl; and fireplaces 24 million bbl in additional savings.

(2) The Cumulative Tax Revenue Losses Through 1985 Increase Significantly As Adaitional Equipment Types Are Assumed Eligible

- Assuming renewable energy tax credits are available for wood heating equipment, total revenue loss for high efficiency stoves only is $\$ 700$ million. Revenue losses increase by another $\$ 500$ million for furnaces, another $\$ 350 \mathrm{million}$ for other stoves and $\$ 1,350$ million for fireplaces. If chimneys are included as eligible for tax credits, the revenue loss for each item of equipment increases by another 50 to 100 percent.

- Even assuming only a 15 percent tax credit for airtight stoves alone, a significantly 
greater revenue loss results compared to solar heating equipment tax creilits, based on a congressional Budget Office (CBO) study.. The present value tax revenue loss for solar heating equipment is approximately $\$ 260$ million (based on tax credits set at 40 percent of the first $\$ 1,000$ plus 25 percent of the next $\$ 6,400)$. By comparison, the present value tax revenue loss for airtight stoves under a 15 percent tax credit assumption if $\$ 417$ million.

Wood heating equipment tax credits where eligibility is limited to high efficiency stoves and furnaces, without chimneys, result in a somewhat lower aggregate revenue loss than do insulation tax credits. Based on the CBO study, insulation tax credits result in about $\$ 2.1$ billion of Federal tax revenue loss. However, if all types of stoves and/or fireplaces are eligible, tax revenue losses are greatiy increased.

(3) Tax Revenue Loss Per Bbl. Oil Saved for Most Residential Nood Burning Equipment Policy Options Is Lower Than for Solar Heating Tax Credits But Higher Than Insulation Tax Credits

The final column in Exhibit III-5 indicates that most wood burning equipment policy options result in a cost per barrel of between $\$ 3$ and $\$ 6$. Solar heating equipment tax credits have a cost per barrel of over $\$ 11$ while insulation tax credits have a cost of about $\$ 2.50 / \mathrm{bbl}$.

It should be noted that each of the cost per bbl. values in Exhibit III-5 are weighted average values for the policy option combinations. However, some individual equipment suboptions have a much higher cost per bbl. than the weighted average. For example, fireplaces result in 24 million bbl. oil saved under a 30 percent tax credit for a tax revenue loss of nearly $\$ 1.4$ billion. This represents a government cost per bbl. of $\$ 56$. (see Exhibit III-4). 
- Since chimneys raise the installed cost for stoves and other items of equipment by 25 to 100 percent without increasing oil savings, the equivalent government revenue lost per barrel of oil saved is increased by 50 to 75 percent. In addition, if fireplaces with chimneys are included, the marginal cost per barrel is over $\$ 110$, ten times the cost per bbl. for solar home tax credits. It is recognized that the potential sales impact of chimney eligibility may influence these results. Both equipment oil savings and tax revenue losses would be affected as previously indicated. The extent of these influences is uncertain, however, and their determination would require an expenditure of time and resources beyond the scope of this task.

(4) Conservation Tax Credits (15 Percent) for Wood Burning Equipment Reduces Both the Oil Savings and Tax Revenue By About 50 percent compared to Renewable Energy Tax Credits ( 30 percent). However, the Efficiency of the Tax Credits in Terms of Revenue Loss Per Barrel of Oil Saved Is Slightly Improved

For comparative purposes, the incremental oil savings and tax revenue loss were computed for each equipment suboption assuming conservation tax credits for residential wood burning equipment. All other assumptions including elasticity of demand and equipment prices remained unchanged. The result of the computation was an almost equal drop in oil savings and tax revenue loss, both to a level of about one-half that for renewable energy source tax credits. The cost per barrel for this option was about 10 percent lower than for renewable energy source tax credits.

(5) The Retroactive Tax Credit Eligibility and Delayed Eligibility Options Affect Equivalent oil Savings, Revenue Loss and Government Cost Per Barrel By Less Than 15 percent

For comparative purposes, oil savings and tax revenue loss were also computed for both retroactive. tax credits to April 20, 1977 and for delayed tax credits to January 1, 1980. Exhibit III-5 shows the 
results of these calculations based on the assumptions for renewable energy tax credits for high efficiency stoves and furnaces without chimneys (row 11 and 12). The key results were as follows:

Retroactive tax credits increase tax revenue losses by about 13 percent compared to immediate eligibility because equipment sold. in 1978 and for seven months in 1977 becomes eligible for tax credit status. Oil revenue savings are unchanged, however, because there are no incremental sales due to tax credits. As a result, the tax revenue loss per bbl. of oil saved is increased, meaning that this option is not as "efficient" as the corresponding immediate eligibility options.

Delayed eligibility options lower the potentisl tax revenue loss by about 10 percent but lower the equivalent oil savings by a similar amount. The tax loss per bbl. of oil saved is essentially unchanged. 


\section{SAFETY AND PERFORMANCE STANDARDS}

The rapid increase in available styles and quantities of residential wood heating equipment has led to a recognition on the part of both building code officials and the industry concerning the need for uniform safety criteria and standards. There also has been a concern for the development of testing procedures for comparing efficiencies of various types of equipment. To date, there has been significant work on the development of standards that are acceptable both to the organizations that will use them, as well as to the industries that must meet them.

The purpose of this chapter is to address the availability of standards and their suitability as criteria for selecting equipment eligible for tax credits. Existing standards as well as those under development are considered. The chapter also includes a discussion of the general effectiveness of standards to respond to all major causes of wood burning related hazards.

This chapter is divided into two major sections:

- Safety Standards

- Efficiency Standards.

\section{SAFETY STANDARDS}

The concern for fire safety in homes has led Underwriters Laboratory (UL) to develop several safety standards as well as a certification program for wood burning equipment. The standards have been revised as needed, and recently a new standard specifically for stoves was proposed

(1) The Primary Function of the UL Standards Is To Ensure Equipment Safety Through Requirements For Proper Design and Fabrication

The development of Underwriters Laboratory wood burner related standards began in 1956. Additional standards were developed in 1958, 1968 and in 1978 as shown in Exhibit IV-1. The four standards and their functions are described as follows: 
- UL-103 contains requirements for factory built chimneys for gas, liquid and solid fuel fired residential type appliances.

- UL-127 requirements apply to factory built fireplaces, which covers the fire chamber, its chimney and related Eactory built parts.

- UL-73.7 contains requirements to cover fireplace stoves, which are freestanding fire chamber assemblies.

- Proposed UL-1482 contains requirements for room heaters which are freestanding fire chamber assemblies of the circulating or direct radiation type.

The updated safety standards, some of which have not yet been adopted, pertain to the safety of wood burning equipment. Typically standards specify the following equipment related requirements:

- Material type and thickness

- Safety performance testing, (i.e., surface temperatures)

- Structural sounōness and material integrity

- Electrical and/or special attachment testing in some cases.

As shown in Exhibit IV-1, equipment related requirements are covered by all four UL standards.

(2) A Secondary Function of UL Standards Involves Recent Changes to Include Consumer Instructions

All of the recent revisions to the Fireplace Stove and Solid Fuel Room Heater standards, as shown in Exhibit IV-1, require manufacturers to supply consumers with important 
EXHIBIT IV-1

Coverage and Status of U.L. Standards for Wood Burning Equipment

\begin{tabular}{|c|c|c|c|c|c|c|c|c|}
\hline \multirow[b]{2}{*}{ STANDARD } & \multirow[b]{2}{*}{ PRODUCT COVERED } & \multicolumn{4}{|c|}{ KEY POINTS COVERED BY PROPOSED U.L. STANDARDS } & \multirow{2}{*}{$\begin{array}{c}\text { ESTIMATED } \\
\text { LEVEL OF } \\
\text { COMPLIANCE } \\
\text { WITH ORIGINAL } \\
\text { STANDARDS }\end{array}$} & \multirow{2}{*}{$\begin{array}{c}\text { EXPECTED } \\
\text { DATE OF } \\
\text { ADOPTION } \\
\text { OF UPDATED } \\
\text { STANDARDS }\end{array}$} & \multirow{2}{*}{$\begin{array}{l}\text { DATE } \\
\text { OF } \\
\text { FIRST } \\
\text { ADOPTION }\end{array}$} \\
\hline & & $\begin{array}{c}\text { PRODUCT } \\
\text { DESIGN AND } \\
\text { MANUFACTURER }\end{array}$ & $\begin{array}{l}\text { INSTALLATION } \\
\text { INSTRUCT IONS }\end{array}$ & $\begin{array}{c}\text { OPERATING } \\
\text { INSTRUCT IONS } \\
\end{array}$ & $\begin{array}{l}\text { MAINTENANCE } \\
\text { PROCEDURES }\end{array}$ & & & \\
\hline UL - 103 & $\begin{array}{l}\text { FACTORY BUILT } \\
\text { CHIMNEYS }\end{array}$ & COVERED & COVERED & LIMITED & NOT COVERED & MOST MANUF. 1 & $\begin{array}{c}2 / 78 \\
\text { ADOPTED }\end{array}$ & $3 / 56$ \\
\hline UL-127 & $\begin{array}{l}\text { FACTORY BUILT } \\
\text { FIREPLACES }\end{array}$ & COVERED & COVERED & LIMITED & NOT COVERED & ABOUT $95 \% 2$ & $6 / 79$ & $10 / 58$ \\
\hline UL-737 & $\begin{array}{l}\text { FIREPLACE } \\
\text { STOVES }\end{array}$ & COVERED & COVERED & LIMITED & $\begin{array}{l}\text { VERY } \\
\text { LIMITED }\end{array}$ & ABOUT $95 \%{ }^{2}$ & $6 / 79$ & $6 / 68$ \\
\hline UL- 1482 & $\begin{array}{l}\text { ROOM HEATERS } \\
\text { SOLID FUEL. TYPE }\end{array}$ & COVERED & COVERED & LIMITED & $\begin{array}{l}\text { VERY } \\
\text { LIMITED }\end{array}$ & $70-80$ & $3 / 79$ & $\begin{array}{c}\text { FIRST } \\
\text { EDITION } \\
\text { PROPOSED } \\
\text { IN } 1 / 78\end{array}$ \\
\hline
\end{tabular}

1 Personal communications, Charles Gibbons, Head of Wood Burner Testing, Underwriters Lab, Northbrook, Illinois.

2 Fireplace Institute letter to Consumer Product Safety Commission, March 9, 1978. 
information pertinent to the proper installation of wood burning units. Typically, instruction manuals are to. contain the following information:

- Parts and materials required for installation

- Step-by-step installation instructions for the whole system

- Information on heat shields and bases

- Exact specifications for stove and chimney attachments

- Recommended clearances from combustible surfaces.

Instruction manuals are to contain limited information pertaining to the recommended operation of the unit. The information is to include warnings pertaining to:

- Disposal of ashes

- Storage and use of flammable liquids as fire starters ${ }^{l}$

- The use of grates, and irons and other methods of supporting the fuel

The operation and use of manual and thermostatic controls

- :. Operation and use of electrical attachments.

Finally, UL-737 and UL=1482 are to contair. limited instructions pertaining to the proper maintenance of the unit. These are limited to:

$1 \quad$ The use of flammable liquids in starting woodfires is strongly discouraged, as specified by proposed revisions of UL-737 and 1482 . 
- Instructions for frequent inspection of stovepipe and chimney to locate creosote deposits ${ }^{2}$

- Procedures for cleaning and removal of creosote deposits.

(3) There Are Indications That Industry Response to the Latest Nood Heater Standards Will Be Favorable

The Wood Energy Institute (WEI), representing most major wood stove manufacturers, has set up a standards committee, to interact with and assist UL in developing the proposed standards. The WEI and other organizations are showing signs of encouraging the acceptance of such standards.

- Each of the four major model building codes in. use in the U.S. contains provisions recuiring tinat fireplacies and yood burnisg stoves be tested and listed by an approved testing laboratory. The testing procedurés: are normally based on UI standards. Many manufacturers, in order to sell products in selected areas of the country, have already sought and received various building code approvals.

- Compliance with previous fireplace and wood burning related equipment standards has been reported to be very high. (Exhibit IV-l).

- The greatest impetus toward manufacturers' compliance with voluntary standards would be the approval of a petition (No. AP 77-2, Coal and Wood Burning Stoves), by the U.S.

$2 \quad$ Creosote deposits are condensed wood burning vapors that accumulate on cooler surfaces within the wood burning system. The accumulation of creosote increases the changes of chimney and chimney connected fires. 
Consumer Protection Safety Commission. ${ }^{3}$

Such action would result in a ruling requiring permanent labeling on all wood burning stoves, appliances, or freestanding fireplaces. The labels would have to contain information pertaining to:

- Minimum clearance to combustibles

- Type of chimney requirements.

The implication of the mandatory Federal labeling rule would be to require manufacturers to support claims with valid data and should provide much needed impetus for participation by manufacturers in voluntary standard programs.

(4) There Has Been Concern on The Part of Industry Regarding The Capacity of Testing Laboratories, But Preliminary Information Indicates That This Should Not Be A Major Problem

Underwriters Laboratory currently has seven stove test stands in its Northbrook, Illinois facility. At a normal rate of one. stove per stand per week, UL can test approximately 350 units per year. Additional capacity can be made easily available.

- There are 10 to 12 other laboratories in the U.S. currently capable of testing stoves. The aggregate capacity of these facilities has been estimated at upwards of 700 units per year.

$3 \quad$ A hearing on this issue was held on March 14, 1979, but no decision is expected until March 22, 1979. If the petition is approved, as recommended by the investigators, it is estimated that its implementation may take 6 to 24 months, depending on the availability of funds. 
(5) Despite the Emphasis to Date on Equipment Safety Standards, Preliminary Evidence Indicates That the Majority of Home Fires Related to Wood Burning Are Not Caused By Equipment Malfunction

To ensure proper and safe functioning of a wood burning system, the individual components must have dependable design characteristics, proper materials and a well-balanced integration of components. The current equipment standards for chimneys, stoves, and fireplaces primarily address this portion of the safety problem.

Despite the concern with equipment safety, however, a recent study suggests that equipment is not the major cause of fires. The National Bureau of Standards recently completed a study of causes of residential fires where wood burning equipment was involved. The results indicate that only 20 to 25 percent of the 10,500 fires studied were equipment related pertaining to:

$$
\begin{aligned}
& \text { - Malfunctions } \\
& \text { - Improper stove design } \\
& \text { Improper chimney design. }
\end{aligned}
$$

Exhibit IV-2 summarizes the major causes of fires.

Insurance companies are just becoming interested in the impact of wood burning on the incidence of home fires. Currently there is no readily available information to evaluate the comparative fire safety implications of wood burning, although. NBS is considering the evaluation of this important issue.

$\overline{4}$ Richard D. Peacock, "A Review of Fire Incidents, Model. Building Codes, and Standards Related to Wood Burning Appliances," NBS, December 1978. 
EXHIBIT IV-2

Causes of Fires Attributed to wood Burning

\begin{tabular}{|c|c|c|c|c|c|}
\hline SPECIFIC CAUSES OF FIRES & $\begin{array}{l}\text { NUMBER } \\
\text { OF FIRES }\end{array}$ & $\begin{array}{l}\text { PERCENTAGE } \\
\text { OF FIRES }\end{array}$ & $\begin{array}{c}\text { FIRES ATTRIBUTABLE } \\
\text { T0: }\end{array}$ & $\begin{array}{c}\text { PERCENTAGE OF: FIRES } \\
\text { ATTRIBUTABLE } \\
\text { TO EQUIPMENT } \\
\text { INADEQUACY } 1\end{array}$ & $\begin{array}{c}\text { PERCENTAGE OF FIRES } \\
\text { ATTRIBUTABLE } \\
\text { TO CONSUMER MISUSE }\end{array}$ \\
\hline Exterior Fire From Sparks & 963 & 9.2 & Consumer Misuse & & 9.2 \\
\hline Chimney Fires & 623 & 5.9 & Equipment/Consumer & 3 & 3 \\
\hline Equipment Malfunction & 457 & 4.3 & Equipment Inadequacy & 4.3 & \\
\hline Use of Flammable Liquids & 126 & 1.2 & Consumer Misuse & & 1.2 \\
\hline Other & 28 & .27 & Equipment/Consumer & .14 & .13 \\
\hline Improper Maintenance & 2,875 & 27.5 & Consumer Misuse & & 27.5 \\
\hline Improper Equipment Design & 1,050 & 10.0 & Equipment Inadequacy & 10.0 & \\
\hline Improper Chimney & 138 & 1.3 & Equipment/Consumer & .65 & .65 \\
\hline TOTAL & 10,560 & 100 & & 22.5 & 77.5 \\
\hline
\end{tabular}

SOURCE: Personal Communication with Richard D. Peacock, National Bureau of Standards, February 8 , 1979.

1. Booz, Allen estiniates 
(6) The Primary Cause of Home Fires Related to Wood Burning Equipment Can Be Attributed to Consumer Misuse

The safety problems associated with wood stove use fall into three main categories:

- Improper installation can result in system breakdown or into more indirect fire hazards such as the ignition of combustibles, exterior fires from sparks, and ignition of structures (see Exhibit IV-2).

- Causes of fires due to improper operations are shown in Exhibit IV-2 to account for 7.5 percent of fires. Improper fueling techniques and the use of flammable liquids are additional examples of improper operation and contribute an additional 6.7 percent of all fires.

- Improper maintenance is shown in Exhibit IV-2 to be responsible for 27.5 percent of wood burning related fires. Chimney fires may partially result from improper maintenance of the chimney, additionally, exterior fires from sparks can be caused by improper maintenance of surroundings.

Interim results of the National Bureau of Standards study indicate that upwards of 70 percent of fires attributed to wood burning are the result of improper consumer care rather than equipment failure. Interviews with dealers, manufacturers and others involved with the wood burning industry revealed that the major cause of fires is consumer misuse.

The predominance of user caused fires is due to several. factors. First, the majority of 
wood stove installations are made by the consumer, 5 and furthermore, many installations are made without obtaining building permits, thus avoiding safety inspections by fire marshals and building inspectors. Finally, even when installation guidelines are included with equipment, many people do not follow the instructions closely. As one manufacturer put it, "the paper used to start the first fire is usually the instruction manual."

- One of the most difficult aspects of safety control is ensuring proper maintenance of the wood burning system. Localities in the U.S., unlike many European countries, do not provide the services of chimney sweeps. Many users of wood burning equipment attempt to service their own wood burning systems, often with inadequate cleaning equipment.

(7) The Major Conclusion That Can Be Drawn on Safety Standards is that Although Suitable Equipment Standards Should Soon Be Available, Significant Effort is Needed to Educate Consumers on Proper Operation and Maintenance

The UL Standards for stoves and other equipment have either been adopted or will be adopted in early 1979 .

Industry acceptance of these standards is expected, but compliance with the standards will not likely occur immediately.

A major aspect of the safety problem that cannot be directly addressed by equipment standards is consumer installations, operation and maintenance.

5 Maine Firewood Study, prepared by Elizabeth w. Swain, wood Fuel Program Director, Maine dudubon Society, Grant No. EC-77-03-1616, November 14, 1978. 
EXHIBIT IV-3

General Categories of Efficiency Variables

For Wood Burning Equipment

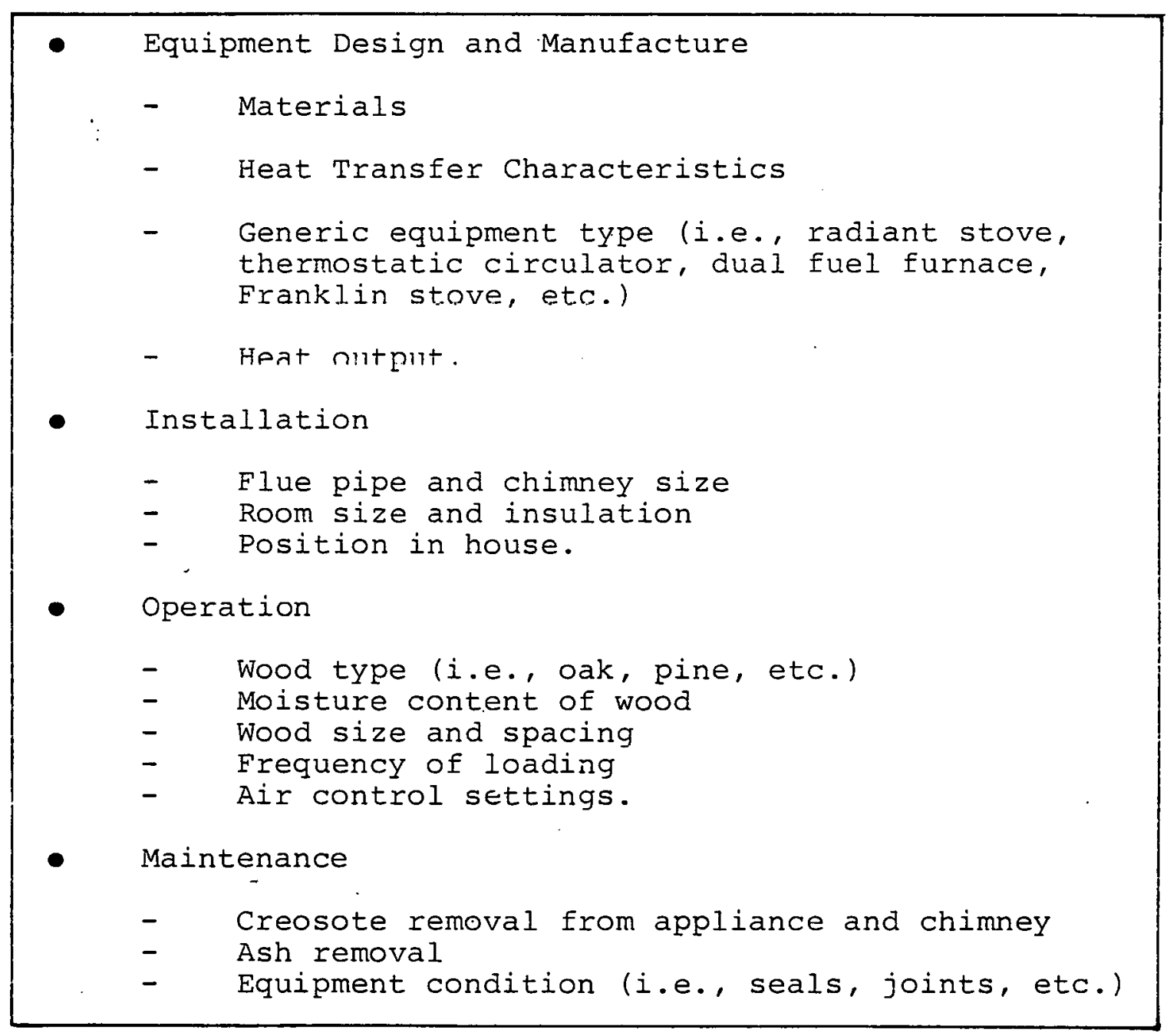




\title{
2. EFFICIENCY STANDARDS
}

Industry and government recognition of the need to establish acceptable efficiency information has resulted in considerable progress towards workable performance standards for wood burning equipment. However, efficiency, like safety, is a product of equipment operation as well as equipment design. The discussion of the efficiency issue in this section is organized into three parts:

\begin{abstract}
Factors affecting uniform efficiency measurement
Current research on efficiency

Status of efficiency standards and developments and implementation.
\end{abstract}

(1) There Are Many Factors Affecting Wood Stove Efficiencies-Making Uniform Measurements Difficult

The efficiency of a wood burning unit is normally defined to be the percentage of useful heat energy output per unit of wood energy input. Factors affecting the efficiency of wood burning devices can be divided into four categories:

- Equipment design and manufacture

- Installation

- Operation

- Maintenance.

Exhibit IV-3 gives examples of the types of factors which affect each of these variables.

- Most efficiency measurements are conducted under laboratory conditions, at steady state loads and on new equipment. Under actual operation in a home, there is a wide variance in operating practices making precise correlations between tested and actual efficiency difficult. 6

Efficiency testing is further complicated by equipment differences. Airtight stoves require somewhat different test standards than freestanding fireplaces, due to the large volume of air intake by the. fireplaces.

6 Jay Shelton, personal communications. 
(2) Current Research on Efficiency Has Generated Considerable Data on the Sensitivity of Performance to Various Factors

The major ongoing program being sponsored by DOE is at Auburn University's Department of Mechanical Engineering. This project is designed to provide efficiency data reflecting a wide variety of variables for major types of wood burning equipment. 7 The most important result of the study is the development of proposed procedures and guidelines defining efficiency standards for the wood burning industry.

Over the last several years, significant efficiency testing has been performed at williams College under the supervision of Dr. Jay Shelton. Selected studies resulting from this work include:

- "Woodstove Testing Methods and Some Preliminary Analysis" which compared the values of two basic efficiency. testing methods.

- "An Analysis of Woodstove Performance" which sought to arrive at comparative efficiency measures for a variety of wood burning units.

- Measured Performance of Fireplaces and Fireplace Accessories" which addressed improving the efficiency of fireplaces.

The Tennessee Valley Authority (TVA) has sponsored several demonstration projects to gather data on the reduction in electric heating which results from the use of wood stoves as supplemental heating sources. Their preliminary findings indicate savings of 60 percent as part of the household's total electric consumption. 8

7 Auburn University, "Improving the Efficiency, Safety and Utility of Wood Burning Units," Quarterly Report, September 15, 1978. 
(3) Based on the Limited Test Data Available, Equipment Falls Into Several General Categories of Efficiency. Because of Rapid Product Development However, These General Categories Do Not Reflect Improvements Being Made

Residential wood burning equipment can be divided into the following efficiency categories:

- Fireplaces are considered to have efficiency ratings between 10 and 25 percent. With some attachments, efficiencies of up to 50 percent have been claimed.

- Franklin stove types and potbelly stoves are generally rated between 20 to 35 percent. Due to the increased efficiency awareness of the consumer many stoves in the lower efficiency range are being discontinued or improved.

- Circulators are considered relatively airtight, but the heat transfer capacity is limited by its double layer construction. Their energy efficiency is generally considered to be between 40 and 50 percent.

- Radiant heaters are generally airtight and are capable of generating a high level of useful heat. Their efficiency ranges between 50 and 65 percent.

Despite the simplicity of categorizing wood burning devices into broad groups for the purpose of policy analysis, this grouping of general categories is inadequate for several reasons. First, wide ranges of efficiencies exist in each group, often falling outside the efficiency range indicated above. Secondly, these efficiency estimates were not based on uniform methods of measurement. In light of the current progress, it appears that more uniform efficiency measurements may soon become available, as indicated in the next section. 
(4) As a Result of the Work Being Performed By Auburn, Separate Standards Are Being Developed For Fireplaces and Wood Burning Stoves

A standard for fireplaces utilizing the calorimeter room method of testing, has already been developed and commercial testing is expected to begin by April 1, 1979. Auburn has a capacity of approximately ten units/month and estimates a cost of approximately $\$ 1,500$ per unit. The Fireplace Institute and Auburn University are seeking the support and approval by ASHRAE (American Society of Heating, Refrigeration and Airconditioning Engineers) of the proposed fireplace standard. 'The proposed standard includes the following features : 9

- A uniform method of testing and rating wood burning units

- Specifications for types of test equipment

- Data required and calculations to be used

- A listing and definitions of terms used in testing.

A proposed standard for wood burning stoves which relies on the flue loss method of efficiency testing (a simpler and less expensive test) is under development and is expected to be completed by the summer of 1979, with testing planned to begin. shortly thereafter. This test can be conducted at a rate of one per day per operating facility. Since the flue loss tests are simple to set up, many testing labs can easily adapt to perform testing functions. The cost has been estimated at approximately $\$ 800$ per unit. 10

9 Personal communication with D. F. Dyer, Auburn University.

10 D. F. Dyer, Ibid. 
(5) The Energy Policy and Conservation Act Directs DOE to Prescribe Efficiency Standards for a Number of Consumer Products, But Does Not Specifically Cover Used Burning Equipment

One stated purpose of the Energy Policy and Conservation Act (EPCA), Public Law No. 94-163, was "to provide for improved energy efficiency of motor vehicles, major appliances, and certain other consumer products."Il Title III, Part $B$ of the EPCA deals with the energy conservation program for consumer products other than automobiles. This specifically includes home heating equipment and furnaces. However, wood-burning equipment is excluded from the effect of this legislation, since EPCA Section 321 defines the term "consumer product" in such a way as to restrict the statute's mandated applicability to those consumer products which use fossii fuels or electricity as an energy source.

EPCA Sections $322(a)(14), 322(b)$ and $325(a)(2)$

(the last provision added by the National Energy Conservation and Policy Act, Public Law No. 94-619) do provide that the Secretary may issue regulations to include "any other type of consumer product" in the efficiency standard program, if he determines that:

- The average per household energy use

- within the United States by products of such type (or class) exceeded 150 kilowatt-hours (or its Btu equivalent) for any 12-calendar-month period ending before such determination;

- The aggregate household energy use within the United States by products of such type (or class) exceeded 4,200,000,000 kilowatt-hcurs (or its Btu equivalent) for any such 12-calendarmonth period;

- Substantial improvement in the energy effiency of products of such type (or class) is technologically feasible; and

I1 Section 2(5) of the EPCA. 
- The application of a labeling rule under section 324 to such type (or class) is not likely to be sufficient to induce manufacturers to produce, and consumers and other persons to purchase, covered products of such type (or class) which achieve the maximum energy efficiency which is technologically feasible to attain and is economically jusitified.

Discussions with a DOE official indicated that the process of adding a non-specified consumer product to the efficiency standards program could take approximately two years, give or take six months.l2

(6) In Conclusion, Even Though Considerable Progress Was Made Toward the Development of Efficiency Standards, Currently There Are No Acceptable Standards That Could Be Used As A Criteria For Tax Credits

- Results from studies conducted at Auburn University and other institutions may soon become available and provide a more uniform efficiency measure.

- Efficiency standards may be enforced through the National Energy Conservation Policy Act by changing the Act through administrative ruling to include wood burning devices.

12 Personal communication with Jim Smith, Director of Consumer Products Division of DOE. 
V. ENVIRONMENTAL IMPACTS 


\section{ENVIRONMENTAL IMPACTS}

There are a number of potential environmental impacts that could result from increased residential fuel wood use. These impacts can be divided into two categories, each of which is discussed in a separate section of this chapter:

- Impacts of increased fuelwood harvesting including water pollution, nutrient balances, and wildlife habitat:

- Impacts of increased fuelwood burning, specifically air pollution.

\section{IMPACTS OF FUELWOOD HARVESTING}

An increase in fuelwood harvesting can have negative as well as positive environmental impacts. Negative effects include water pollution problems, deforestation, loss of soil nutrients, and damage to residual stands. Positive impacts include enhanced wildlife habitat, improved productivity and an increased awareness of the importance of forest management. These potential effects are described below.

\section{(1) Negative Effects}

Increased Fuelwood Harvesting Especially If Done on a Large Scale Could Cause Water Pollution Problems

The extent and severity of water pollution impacts which result from increased demand for firewood are directly dependent on the manner in which the firewood is obtained. Under certain conditions, typically involving large scale timber harvesting operations, water pollution impacts can be severe. In the case of small-scale efforts by individual citizens, pollution impacts are not likely to be significant. 
In general, water pollution can result from four basic activities entailed in silvicultural operations: building and use of transportation systems; harvesting of timber; site restoration, including soil stabilization and replanting; and intermediate practices, such as thinning and spraying for control of fire, insects, and disease. Principal water quality impacts of these activities are erosion and subsequent stream sedimentation; increased runoff and decreased infiltration; runoff of organic debris, fertilizers, and chemicals; and thermal pollution resulting from loss of tree canopy.

These pollution problems will not result from all wood gathering or harvesting operations. As noted earlier, the severity of the problem will depend on the physical characteristics of the site and the specific methods employed to harvest the wood. In addition, problems can be avoided through the application of preventative measures. Extensive research has been undertaken over recent years in the area of controlling and preventing water pollution resulting from silvicultural operations. 1 The emphasis of this research has been on the development of "Best. Management Practices" or "non-structural" pollution controls. These techniques are required under many forest practices acts, notably those laws in the Northwest U.S. In addition, trained foresters employed by the Federal and state governments are often available to provide professional guidance to individuals who are unfamiliar with proper harvesting techniques. There is every reason to believe, therefore, that water pollution problems associated with silviculture can be minimized if not eliminated through the consistent application of these methods.

I See, for example, U.S. EPA, Region $X$, Logging Roads and Protection of Water Quality. EPA 910/9-75-007; U.S. EPA. Office of water and Air Programs, Processes; Procedures, and Methods to Control Pollution Resulting from Silvicultural Activities, EPA 430/9-730I0; U.S. EPA, Office of Water Planning and Standards, Nonpoint Source Control Guidance: Silviculture, March, 1977. 
Increased cutting could result in deforestation.. While wood is a supplemental heating fuel in this country, it is the primary fuel for both heating and cooking in many underdeveloped parts of the world. In many of these areas, limited supplies and excessive demands have created a virtual firewood crisis. ${ }^{2}$ The problem is particularly severe in the Indian subcontinent where entire forests have been denuded. In South Korea, moreover, hillsides have been cut and raked clean of all leaves, litter, and burnable material. The environmental consequences of such activities are severe and wide reaching. Increased soil erosion not only reduces soil productivity, it also leads to increased sedimentation of streams. As water courses become clogged with silt, furthermore, the danger of downstream flooding becomes especially serious.

Despite these problems in other parts of the world, similar difficulties are not likely to occur in this country. Supplies are more than adequate to meet even sharp increases in demand, 3 and even if regional shortages were expected, deforestration could be prevented through nroper supervision and forest management.

Increased wood cutting by non-professionals could result in damage to residual stands or loss of commerically valuable trees. A potential problem which is more likely than deforestation involves the improper cutting of trees. It is well recognized that not all trees are best suited for use as firewood. Some individuals who cut wood for their own fuel use may be unaware of the commercial potential of some types of wood, however, and consequently they may cut the most valuable of

\footnotetext{
2 For a discussion of the worldwide shortage of firewood, see Erik Eckholm, "The Other Energy Crisis: Firewood," Woridwatch Paper \#1. (washington, D.C.: Worldwatch Institute, 1975).

See Chapter VI, "Resource Availability."
} 
those trees which are the straightest and most easily felled. Alghough these are indeed potential problems which could become serious with a sharp increase in fuelwood demand, it should be noted that a preliminary survey of state and Federal foresters indicated that it is not now a widespread problem on public lands. The problem could become more severe, however, if greater numbers of persons inexperienced in wood cutting begin gathering wood for fuel use.

Increased cutting and removal of debris could lead to a loss of soil nutrients. Natural nutrient levels in soil are maintained largely by the decomposition of forest products on the forest floor. A constant supply of decomposing materials is provided by natural processes and by debris left after cutting operations have ceased. Stumpage and wastewood are well suited for use as firewood, but removal of excessive amounts of this matter could threaten the productivity of future stands by eliminating future sources of nutrients. Research or this issue is inconclusive. Several studies 4 suggest that removal of debris could lead to nutrient depletion over time, while other research suggests that limited cutting and removal can enhance nutrient levels through decay of new growth.

The loss of soil nutrients is avoided in Wisconsin where firewood gatherers are not allowed to remove naturaliy downed or rotting trees; firewood can only be taken from trees that have been cut by state foresters or which have been marked for cutting. Provisions of this sort, coupled

4 See, For example, "The Governor's Task Force on wood as a Source of Energy," State of Vermont, 1975, and refererces cited therein including J.R. Boyle and A.R. Ek, "An Evaluation of Some Effects of Bole and Branch Pulpwood Harvesting on Site Macronutrients, Canadian Journal of Forest Research, 2407 (1972). 
with adequate supervision, can also prevent the removal of stumpage and other debris that serves as valuable wildlife habitat, and can prevent damage to residual trees. In one Virginia state forest, a retired person supervises the firewood gathering effort on weekends and ensures that trees are taken in a manner that does not cause environmental damage.

(2) Positive Impacts

Increased harvesting of wood can provide valuable wildlife habitat. A diverse forest environment exhibiting a variety of types and maturities of veqetative growth offers great potential as wildlife habitat. This sort of environment is best achieved where sunlight can penetrate the tree canopy and and where ground vegetation can flourish. These conditions are not typical of a mature, undisturbed bole stage forest. Harvesting of trees can create a more diverse habitat for wildlife by opening up the forest to increased light penetration and by providing cover in the form of felled treetops, branches, and other debris. Clearly, in the early stages of forest harvesting operations, the wildlife population is disturbed, but in many cases, the population increases after operations have been completed.

Increased harvesting of wood could provide a more productive environment for tree growth. There is agreement among many professional foresters that an increased. demand for firewood will have beneficial effects on forest productivity. A sharp increase in demand for firewood in one Virginia forest illustrates this type of impact.

Pocohantas State Forest is located ten miles south of Richmond, Virginia. In the past several years there has been an increased demand for permits to gather firewood from the forest. Prior to this trend, state foresters were having difficulty selling 
certain low grades of wood which had to be cut in order to prepare sites for reforestation. This wood was subsequently made available as firewood, however, and since that time, excellent site preparation has been gained. In addition, needed thinning of young stands has been accomplished.

A similar situation was described by the Chief of the Maine Forest Service who noted that one of the greatest problems in New England forests is the overstocking of low grade hardwood. These trees must be thinned in the interest of overall forest health, but no commercial market for the removed wood is available. The wood is suitable-for firewood, however, and if it were continuously cut and. made available for that purpose, forest productivity would be enhanced.

An increase in private fuelwood cutting could highlight the need for expanded information programs on the topic of proper management techniques. Several state and Federal foresters contacted believe that an increased demand for firewood could have an overall benefit in that it would necessitate the establishment of more extensive public education programs on the subject of woodcutting and forest management. As discussed above, many potential environmental problems resulting from cutting can be avoided through the use of proper techniques, but not all individuals who cut wood have the necessary knowledge. Although some educational programs currently exist, these could be strengthened to provide more comprehensive coverage, and to ensure that all individuals who cut wood do so in an environmentally sound manner.

5 George Bourassa, Maine Forest Service, and Ted Natti, State Forester, State of New Hampshire, in telephone interviews, January 25\&26, 1979. 
EXHIBIT $V-1$

Uncontrolled Emission Factors For Wood, Coal, Gas, and Oil Combustion (In Pounds Per Million Btu)

\begin{tabular}{|c|c|c|c|c|c|}
\hline Fuel/Pollutant & Particulates & So $_{x}$ & co & Hydrocarbons & $\mathrm{NO}_{x}$ \\
\hline WOOD & & & & & \\
\hline Small stove & $0.4-3.0$ & NA & 26 & NA & NA \\
\hline Fireplace & 2.0 & 0 & 12 & 0.5 & 0.1 \\
\hline $\operatorname{COAL}{ }^{*}$ & 0.8 & 1.52 & 0.4 & 0.12 & 0.24 \\
\hline $\mathrm{GAS}^{*}$ & $0.005-0.014$ & 0.0005 & 0.018 & 0.007 & 0.073 \\
\hline OIL* & 0.17 & 1.98 & 0.34 & 0.007 & 0.124 \\
\hline
\end{tabular}

Source: Calculations based on emissions factors given in EPA publication, Compilation of Air Pollutant Emissions Factors, (AP-42).

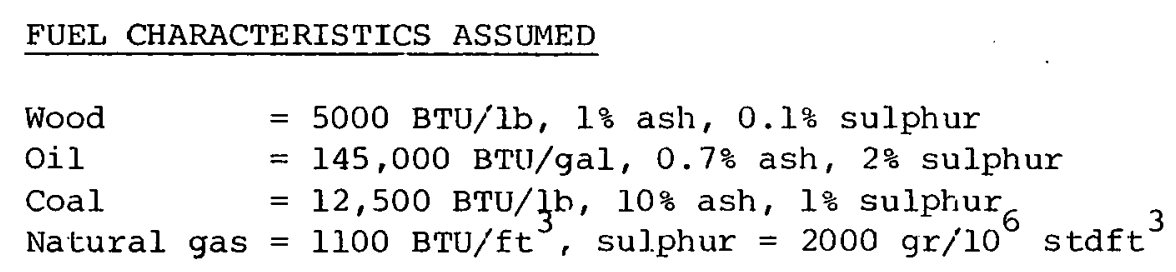

* For residential heating equipment 


\section{IMPACTS OF INCREASED FUELWOOD BURNING}

An increase in residential fuelwood burning will undoubtedly cause air pollution problems in some areas and contribute to existing problems in others. While it is not possible to predict specific impacts or to quantify a national air quality impact due to the tremendous variability among residential wood burning operations, a preliminary assessment can be made.

(1) The Air Pollution Potential of Wood Burning Differs from That of Conventional Fuels

In assessing the air pollution impacts of wood burning, emission factors for five categories of pollutants must be considered. These are particulates, sulphur oxides, carbon monoxide, hydrocarbons, and nitrogen oxides. Factors for these categories are provided in Exhibit $V-1$ for oil, gas, coal, and wood fuels. It should be stressed that actual emissions will vary significantly according to specific characteristics of the fuel, burning conditions, and the burning device that is used.

(2) Principal Air Pollution Problems Stemming From Wood Combustion are Particulates and Chemical Emissions

Particulates and chemical emissions are both associated with the large amounts of smoke emitted by wood burning. Carbon dioxide emissions may also be significant in some cases.

One of the major types of pollutants which result from wood burning is particulate emissions. Accurate estimates of quantities of particulates which could be expected to result from increased residential wood burning are difficult to obtain due to the considerable variation among burning methods and devices. It is recognized, however, that wood burning emits greater amounts of particulates than 
either oil or gas. (See Exhibit V-1). Several sources suggest, furthermore, that the quantity of emissions (including particulates) generally increases inversely with the completeness of combustion.' Thus, inefficient burning methods produce greater amounts of particulates than more efficient devices.

Some chemical emissions from wood combustion may be hazardous, but little conclusive data is available. Wood, as well as fossil fuels, contains trace elements which if present in sufficient quantities are potentially hazardous. Some of these elements, furthermore, have been identified by EPA as toxic substances. During the combustion process these toxic elements can vaporize or form particulates which become entrained in the emissions. Exhibit V-2, which provides some data, suggests that wood generally contains fewer trace elements than coal, with the exceptions of cadmium, chlorine, copper, manganese, mercury, and zinc. It is difficult to predict air pollution impacts from these data, however, since no emission factors for biomass are available.

Potential problems relating to the production of polycyclic aromatic compounds from wood burning have also been suggested. It is well established that these potentially carcinogenic substances are produced by wood burning, but very little is known about the extent of the problem, or whether in fact a problem exists. Some research has been undertaken by segments of the food processing industry, but the results are not directly applicable to fuelwood burning.

1. See, for example, J. D. Milliken, "Wood Combustion Commercialization Program-Environmental Aspects," Industrial Environmental Research Laboratory, U.S. EPA, Research Triangle Park, NC, January 1979; Samuel Butcher, "The Impact of Residential Heating by Hood Stoves on Ambient Air Quality," A report to the Maine Department of Environmental Protection, April, 1978. 


\begin{abstract}
Carbon dioxide emissions from wood burning may be significant, but the potential for problems is not completely understood. In recent years there has been some discussion of a "greenhouse" effect and consequent climate changes which might result from gradual but significant increases in $\mathrm{CO}_{2}$ emissions from fossil fuels. This question is far from resolved. Several sources downplay the problem by arguing that the amount of $\mathrm{CO}_{2}$ produced from wood combustion is equal to the amount which would be created from natural decomposition. While this is true, this argument fails to recognize the fact that the potential concentrations of $\mathrm{CO}_{2}$ resulting from wood combustion would be greater since $\mathrm{CO}_{2}$ would be released at one point and at one time.

The question of $\mathrm{CO}_{2}$ release from wood burning and reforestation has been investioated in several recent studies, 2 and while the findings are not conclusive, they are worthy of note. One of these studies provides figures on the input of $\mathrm{CO}_{2}$ into the atmosphere from non-fossil wood burning and other sources; these are provided in Exhibit $\mathrm{V}-3$. It is evident from the table that the burning is very small compared to other sources, most notably fossil fuel burning. The second of the studies stresses the importance of deforestation as a contributor to increased $\mathrm{CO}_{2}$ levels. Unfortunately, neither study provides definitive evidence concerning the environmental impacts of $\mathrm{CO}_{2}$ emissions resulting from increased levels of wood burning.
\end{abstract}

2 G.A.S. Adams and M.S.M. Mantovani; "Wood Versus Fossil Fuel as a Source of Excess Carbon Dioxide in the Atmosphere: A Preliminary Report," Science, April 1, 1977. pp. 54-55; C.S. Wong, "Atmosphere Input of Carbon Dioxide from Burning Wood," Science, April 14, 1978, pp. 197-200. 
(3) Sulphur Dioxides, Nitrogen Oxides, and Hydrocarbon Emissions from Wood Burning Do Not Appear to Pose Air Poliution Threats

The potential for air poliution impacts resulting from these substances is briefly discussed below.

- Because of its low sulphur content the burning of wood does not contribute significant levels of sulphur oxides to the atmosphere. Compared to oil and coal, wood is virtually sulphur free. In fact wood contains .01 to .05 percent sulphur compared to 1 to 3 percent for oil and coal. ${ }^{3}$

Residential fuelwood burning is not likely to produce appreciable quantities of nitrogen oxides. Because wood combustion typically occurs at approximately $1,500^{\circ} \mathrm{F}$ or less, nitrogen oxides are not commonly produced. The ex-.. ception to this is combustion in efficient wood boilers which reach higher temperatures.

Hydrocarbons emitted by wood burning do not appear to be a significant problem, yet research on the subject is far from complete. Certain types of hydrocarbons can become an air pollution problem when produced in the presence of sunlight and substances easily capable of giving off oxygen. In such cases, photochemical oxidation can be problemmatic. The amount of hydrocarbons produced by wood combustion is small when compared to production associatied with other fuels, including coal and petroleum. One study has indicated that the annual yield from agricultural

3 Jay Shelton and Andrew B. Shapiro, The Woodburner Encyclopedia (Waitsfield, Vermont: Vermont Crossroads Press, 1976), p.9. 
burning in the San Francisco area in 1966 approximated the daily yield from automobiles.4 The applicability of this study may be somewhat questionable, however, since more stringent automobile emissions regulations may have reduced overall hydrocarbon levels and since the study did not relate specifically to residential woodburning. The research does provide a basis for a gross level of magnitude comparison, however. Thus, while the potential problems relating to hydrocarbon production do not appear to be severe, literature on the subject is Iimited, and more research is clearly needed before potential problems can be dismissed as insignificant.

(4) Emission Factors for Wood Burning Vary Greatly and Make Prediction of Specific Air Pollution Impacts Difficult

Air pollution impacts which will result from increased wood burning will depend on a variety of factors including the geographical location, the characteristics of the fuel, and the conditions of the combustion process. These factors are described in more detail below.

The geographical location of the wood burning
will influence whether air pollution impacts
are felt. As with conventional fuels, the air
pollution impact of emissions from wood burn-
ing will depend on topographic and meteorolog-
ical conditions, as well as on current back-
ground levels of pollutants. Topographic and
meteorologic conditions are important in terms
of the air circulation that is provided. Air
pollution problems for wood burning have been
reported in locations where circulation is
poor and where atmospheric inversions are
characteristic. Areas which have experienced
problems from wood burning under these condi-
tions include Vail, Colorado, lowlying valleys
in Vermont, and Yosemite Valiey, California.

4 J. Alfred Hall, "Forest Fuels, Prescribed Fire, and Air Quality." U.S. Department of Agriculture, Pacific Northwest Forest and Range Experiment Station, Portland, Oregon, 1972. 
The impact of wood burning also depends on the current air pollution background levels and the density of development present. Where residential density is high and where many homes burn wood, an overall increase in wood burning obviously will pose a greater air pollution threat than burning in isolated areas. Where air pollution background levels due to industrial emissions are high, furthermore, wood burning is likely to compound existing problems. Such a situation has been reported in the Medford-Ashland area of Oregon.

The characteristics of the wood burning activity greatly influence emission factors. Research in wood combustion has suggested that emission factors associated with wood burning vary according to a variety of conditions including:

- Fuel load
- $\quad$ Muel combustion rate and temperature
- $\quad$ Toisture content and density of fuel
- $\quad$ Burning conditions (e.g., draft setting)
- Fire stoking techniques
- $\quad$ Fuel configuration (e.g., split/unsplit).

Fuel combustion rate is important, for example, because incomplete combustion has been shown to be associated with an increase in particulates as well as carbon monoxide and hydrocarbons. While efficient combustion is generally consistent with low emission factors, this is not the case with the production of $\mathrm{NO}_{x}$ in high temperature boilers.

Other research has demonstrated the importnace of the type of wood burning device in terms of emissions. Exhibit V-4 illustrates this variation in emission factors among four types of burning equipment. In addition to types of equipment, furthermore, the type of wood used can produce significant differences in emissions factors. By plotting grams of particulates to kilograms of different types of wood burned in fireplaces, one study obtained a range in particulate emissions 
EXHIBIT $V-2$

Typical Levels of Trace Elements in Fossil Fuels and Biomass

\begin{tabular}{|c|c|c|c|c|c|}
\hline Element & \multicolumn{2}{|c|}{ Coal } & \multicolumn{2}{|c|}{ Oil } & 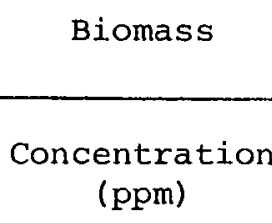 \\
\hline
\end{tabular}

${ }_{b}$ Based on Heating Value of $11,200 \mathrm{Btu} / \mathrm{lb}$ for coal as burned.

Based on Heating Value of $18,400 \mathrm{Btu} / 1 \mathrm{~b}$ for residual oil as burned.

Elements and associated compounds are identified by EPA as toxics.

$d_{C h l o r i n e}$ and fluorine are not toxics according to EPA, but compounds containing these elements are identified as toxic substances.

Source: Energy Research and Development Administration, Fuels from Biomass, p. 119. 


\section{EXHIBIT $\urcorner-3$}

Input of $\mathrm{CO}_{2}$ into the Atmosphere from Nonfossil Woodburning and Other Sources

\begin{tabular}{|c|c|c|}
\hline & \multicolumn{2}{|c|}{ Carbon } \\
\hline & $\begin{array}{l}\text { Gross } \\
\left(10^{1} \text { g year }^{-1}\right)\end{array}$ & $\left(10^{\text {Net }}\right.$ g year $\left.^{-1}\right)$ \\
\hline $\begin{array}{l}\text { Fires in boreal and temperate } \\
\text { forests and nonwooded areas }\end{array}$ & 0.47 & 0.0 \\
\hline $\begin{array}{l}\text { Tropical shifting cultivation or } \\
\text { land already in use }\end{array}$ & 3.0 & 0.0 \\
\hline New tropical forest clearings & $1.5(0.7-2.2)$ & $1.5(0.7-2.2)$ \\
\hline Fuelwood burning & 0.2 & $0.006(0.004-0.008)$ \\
\hline Paper waste burning & 0.08 & 0.0008 \\
\hline Soil carbon loss in agriculture & 0.3 & 0.3 \\
\hline Soil carbon loss on burning & 0.4 & $0.02^{\circ}$ \\
\hline Desertification & 0.05 & 0.05 \\
\hline Urbanization of farmland & 0.01 & 0.01 \\
\hline Fossil fuel burning & 5.0 & 5.0 \\
\hline Respiration of land biota & 63.0 & 0.0 \\
\hline Decomposition of land detritus & 37.0 & 0.0 \\
\hline Respiration of ocean biota & 25.0 & 0.0 \\
\hline Decomposition of ocean detritus & 35.0 & 0.0 \\
\hline Total & 171.0 & 6.9 \\
\hline
\end{tabular}

Source: C.S. Wong, "Atmospheric Input of Carbon Dioxide from Burning Wood," p. 199. 
EXHIBIT V-4

Comparison of Emission Factors of Wood Combustion Devices

\begin{tabular}{|c|c|c|c|c|c|}
\hline Type of Device/Pollutant & Particulates & so $_{x}$ & Hydrocarbons & $\mathrm{CO}$ & $\mathrm{NO}_{x}$ \\
\hline $\begin{array}{l}\text { Wood Boilers } \\
\text { (without fly ash injection) }\end{array}$ & $2.5-7.5$ & 0.75 & $1-35$ & $1-30$ & 5 \\
\hline Fireplaces & 10 & 0 & 2.5 & 60 & 0.5 \\
\hline Small Wood Stoves & $2-15$ & $\mathrm{~N} / \mathrm{A}$ & $\mathrm{N} / \mathrm{A}$ & 130 & $\mathrm{~N} / \mathrm{A}$ \\
\hline Conical Burners.Using Wood Refuse & 0.5 & 0.05 & 5.5 & 65 & 0.5 \\
\hline
\end{tabular}

$\mathrm{N} / \mathrm{A}=$ Data Not Available

Source: U.S. EPA, Office of Air Quality Planning and Standards, Compilation of Air Pollutant Emission Eactors, AP-42, 1977. 
of 5.9 to $16 \mathrm{gm}$ per $\mathrm{kg}$ burned. 5 Finally, the draft setting of a stove can be important since the emission factors of particulates tend to increase as the available air is reduced. 6

One Attempt to Assess Potential Air pollution Impacts Suggests that Increases in Particulate Emissions Could Be Dramatic in Urban Areas where the Total Heating Load Is Assumed by Wood Fuel

Despite the difficulty of predicting impacts, some efforts have been made to assess potential air pollution problems resulting from increased fuelwood burning. Professor Samuel Butcher of Bowdoin college attempted to model impacts that could be expected, based on various assumptions, in several cities in Maine. That research indicated that small stoves, operated in a conventional manner, could contribute up to $100 \mu \mathrm{g} / \mathrm{m}^{3}$ to ambient particulate levels if they were to assume 100 percent of the heating load. A residential density of 700 to 1,000 units per square kilometer was assumed. The study also examined the potiential impacts of less than total reliance on woodfuel. Assuming that only 4 percent of the total heating load were provided by wood, the research indicated that the contribution of wood smoke to the urban particulate load could reach $8 \mu \mathrm{g} / \mathrm{m}^{3}$. Clearly, the impact of an increased particulate load will vary depending on atmospheric conditions and current background levels.

In order to place the study findings in perspective, it is useful to compare these potential increases to existing pollutant levels and to Federal standards for

5 U.S. Environmental Protection Agency, "Source Sampling Residential Fireplaces for Emission Factor Development," EPA-450/3-76-010, November, 1975, pp. 2-8.

6 Butcher also discusses these factors in his paper. See, for example, Samuel S. Butcher, "A Preliminary study of Particulate Emissions From Small Wood Stoves," Journal of the Air Pollution Control Assocation 27 (April, 1977) : 346-348. 
particulates. Exhibit V-5 provides that comparison. In general, it appears that unless a considerable proportion of the population begins utilizing wood as their only fuel source, incremental increases of particulates from wood burning would not alone cause Federal ambient air quality standards to be violated in these two cities, even on a worst case basis. It should be stressed that extrapolation of these conclutions is unwise and that a considerably larger amount of data is necessary in order to better understand potential impacts.

(6) Where Woodstove Owners Use Stoves to Burn Coal, Air Pollution Impacts May Be Problemmatic

In some cases, wood stove owners may burn coal rather than wood in their stoves. In light of the higher emission factors of coal versus wood for $\mathrm{SO}_{\mathrm{y}}$ and particulates (see Exhibit V-I), one should consider the potential air pollution impacts of coal burning. Unfortunately, it is not possible to assess impacts with any certainty for several reasons. First, data on emissions factors in coal burning in various types of wood stoves are an insufficient basis for drawing conclusions. Secondly, there is uncertainty regarding the numbers of wood stove owners who will burn coal, since total use will be limited by the type of stove and the availability of coal. Stove type is an especially important consideration since not all stoves are structurally suited for coal burning.

In light of these uncertainties, one must conclude that the air pollution potential of coal burning in wood stoves should be recognized, but that the severity of the problem cannot be estimated at this time.

\section{CONCLUSION}

In conclusion, increased harvesting and burning of wood will have negative as well as positive environmental effects. It is difficult to predict specific impacts, however, due to the significant variabilities in harvesting and burning techniques as well as in the application of control measures.

Wood harvesting activities pose a threat to the quality of nearby water bodies as well as the overall forest environment, but many of these negative impacts can be avoided or controlled through the application of sound forest management practices. Increased wood harvesting, furthermore, can 
EXHIBIT $\nabla-5$

Potential Increases in Particulate Matter

from Wood Burning Strives-

Based on Butcher's 1978 Study

\begin{tabular}{|c|c|c|c|}
\hline Location & $\begin{array}{l}\text { Highest Incremental } \\
\text { Particulate Load } \\
\text { Predicted }{ }^{*}\left(\mu \mathrm{g} / \mathrm{m}^{3}\right)\end{array}$ & Current Air Quality & $\begin{array}{l}\text { Federal Primary Ambient } \\
\text { Air Quality Standard } \\
\text { for Particulates }\end{array}$ \\
\hline $\begin{array}{l}\text { Bangor (1978) } \\
\text { Millinocket (1976) }\end{array}$ & $\begin{array}{l}72-109^{\mathrm{a}} \\
7-11^{\mathrm{b}} \\
75^{\mathrm{a}} \\
7.5^{\mathrm{b}}\end{array}$ & $\begin{array}{l}6 \text { out of } 67 \text { sampless } \\
\text { exceeded } 100 \mu \mathrm{g} / \mathrm{m}^{3} ; \\
\text { geornetric mean }=54 \\
4 \text { out of } 5 j \text { samples } \\
\text { exceeded } 100 \mu \mathrm{g} / \\
\mathrm{m}^{3} ; \text { geomet }=i c \text { mean } \\
=48\end{array}$ & $\begin{array}{l}\text { Annual geometric mean }= \\
75 \mu \mathrm{g} / \mathrm{m} \\
\text { max. } 24 \mathrm{hr} \text {. concentra- } \\
\text { tion } 260 \mu \mathrm{g} / \mathrm{m} \text { not more } \\
\text { than once a year }\end{array}$ \\
\hline
\end{tabular}

*Worst case

$a_{\text {Assumirig }} 100$ percent of Heating Load

$\mathrm{b}_{\text {Assuming }} 4$ percent of Heating Load

Source: Butcher, "The Impact of Residential Heating by Wood Stoves on Ambient Air Quality," and telephone conversation with staff of Maine Department of Environmental Protection. 
result in positive impacts on wildlife habitat and forest productivity. Air quality may be threatened since increased burning of fuelwood will in some cases cause air pollution problems. These impacts may be severe in certain cases, depending on such factors as atmospheric conditions, residential density, and wood burning techniques, but they may be inconsequential in other instances. While potential impacts resulting from increased fuelwood harvesting use do not appear to be troublesome, very little research has been done on the subject, and thus, before conclusive determinations are made, considerably more detailed investigations should be undertaken. 7

7 Milliken refers to four studies that are presently investigating wood combustion. See J.D. Milliken, "Wood Combustion Commercialization Program - Environmental Aspects," Industrial Environmental Research Laboratory, U.S. EPA; Reserach Triangle Park, N.C., January, 1979. 
VI. RESOURCE AVAILABILITY 


\section{RESOURCE AVAILABILITY}

From a national perspective, this country's wood resource is generally acknowledged to be very substantial. Since the oil embargo of 1973, the demand for wood as fuel has been rising, however, and there is a question as to the long-term ability of the timber supply to meet this demand. Furthermore, there have been reports of isolated winter shortages of cordwood in several New England states. The purpose of this chapter is to review and present the best available information on the national and regional availability of wood for residential usage.

1. SUPPLIES OF FUELWOOD IN THE UNITED STATES ARE SUBSTANTIAL

Without question, the supplies of fuelwood in this country are sufficient to meet vast increases in demand. 1 Fuelwood is available from a number of sources which can be tapped without depleting supplies of commercially valuable timber. Several sources of fuelwood, most notably net annual growth and residues of forest materials, offer considerable potential. The various categories of available fuelwood and estimates of energy potential that the supply represents are discussed in the following points.

(1) Large Quantities of Fuelwood Can Be Drawn From a Number of Categories of Reserves Including Surplus Growth, Noncommiercial Reserves, Residues, and Annual Mortality

The major categories of fuelwood are as follows:

Surplus growth. One potential source of fuelwood is net annual growth in commercial and noncommercial forests. This measure as taken by the U.S. Forestry service is calculated by subtracting annual removals of timber from annual growth.

$1 \quad$ This conclusion is supported by Dr. Gil Dempsey, U.S. Forest Service Laboratory, Princeton, West Virginia, in a telephone conversation, January 25, 1979 . 
- Logging residues. Commercial timber operations leave large quantities of branches, bark, twigs, and leaves in the forest after operations have ceased. Some operations, furthermore, utilize only the bole of the tree, leaving approximately $30-40$ percent of the total above ground growth on the site. While some companies presently make these residues available as firewood, the potential of this resource has not yet been tapped.

- Mill residues. Typical mill operations create byproducts which are not commercially marketable but which could be used as fuelwood. Examples are slash and bark chippings.

- Noncommercial timber and noncommercial forest land. Noncommercial timber includes deformed, small, dead, or undesirable softwoods as well as many hardwoods. Noncommercial forest land includes wood growing on unproductive sites or in areas set aside by the U.S. Forestry Service as deferred or reserved.

- Annual mortality. An additional source of fuelwood is trees which have died from natural causes. These trees are suitable for fuelwood if they are harvested before they become rotten.

(2) The Overall Supply of Fuelwood is Adequate to Meet Vast Increases in Residential Wood Burning

It has been estimated that the supplies of woodfuel in this country represent an annual energy potential of roughly 9 quads, $2-3$ of which are considered readily recoverable. 1 specific details related to quantities of available fuelwood are provided below.

Supplies from net annual growth alone could provide 1-4 quads. According to the U.S.

$1 \quad$ Estimate is taken from presentation of Jim Dollard, U.S. Department of Energy, at a seminar on wood combustion held in McLean, Virginia, January 11, 1979. These figures are comparable to estimates made by the Mitre Corporation in Salo; et.al., "Near Term Potential of Wood as a Fuel," Mitre Technical Report MTR-7860, The Mitre Corporation, McLean, Virginia, July, 1978. 
EXHIBIT VI-

Potential Fuelwood Sources

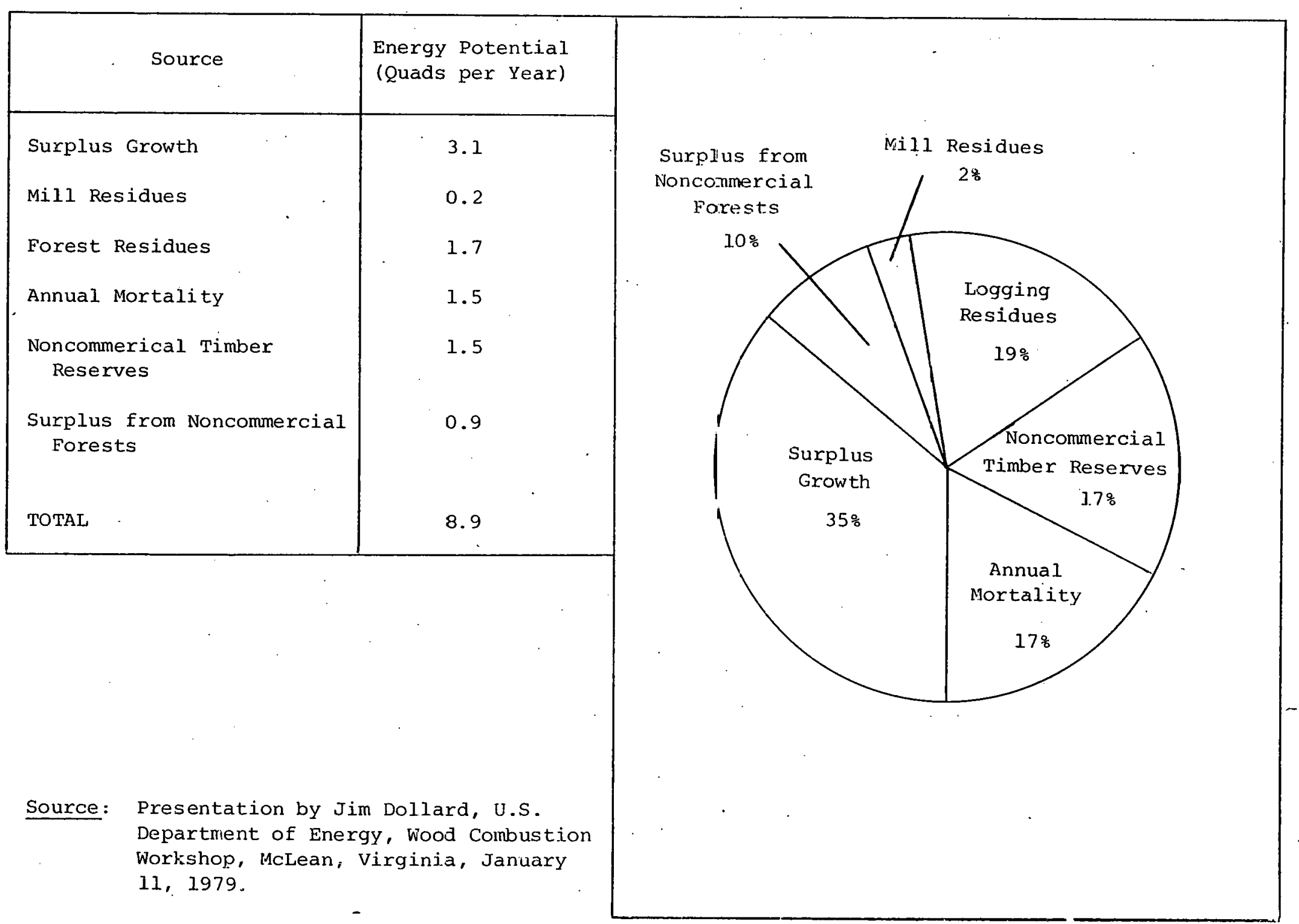


Forest Service, 1 the net annual growth of commercial stocks is 4.5 trillion cubic feet. At 85 cubic feet and 20 million Btu per cord, surplus growth from commercial forests could supply 1.1 quads per year. Assuming, furthermore, a typical use of five cords per house, this resource alone could supply a significant portion of the heating load for over $10 \mathrm{mil}-$ lion homes. One source has suggested that the potential of surplus growth is even greater, estimating growth from commercial as well as noncommercial lands to be 4 quads per year. 2

In addition, supplies from mill and logging residues, noncommercial timber stands, and annual mortality could provide 4.9 quads. statistics concerning fuelwood sources were presented at a recent meeting on the subject of fuelwood commercialization. 3 According to that presentation, annual contributions of other categories of tuelwood supply are as follows: $\mathrm{mill}$ and forest residues 1.9 quads, 4 annual mortality 1.5 quads, noncommercial timber stands 1.5 quads. A summary of the quantities and relative percentages of all categories of fuelwood reserves is presented in Exhibit VI-1.

The total estimate of 9 quads could be increased considerably by supplies resulting from improved forest management techniques and commercial cultivation of wood. According

1 U.S. Department of Agriculture, Forest Service, The Outlook for Timber in the United States, Forest Resource Report No. 20, October, 1973.

2 Presentation by Jim Dollard, DOE, wood combustion seminar, January 11, 1979.

3. Presentation by Jim Dollard, DOE, wood combustion seminar, January 1i, 1979.

4 This general estimate of the contribution of forest and mill residues is supported by T. H. Ellis who estimates a total contribution of harvesting residues in 1973 to be 2.2 quads. T. H. Ellis, "The Role of Wood Residue in the National Energy Picture," in Wood Residue As An Energy Source, proceedings of the Forest Products Research Society Energy Workshop, Eenver, Colorado, September, 1976. (Madison, Wisconsin: Forest Products Research Society, 1977), p. 19. 
to one author, forest productivity can double if forest management practices are utilized.1 Additional wood supplies could come from commercial tree farms which represent a potential supply of 4.5 quads according to one study. The estimate of 9 quads presented above understates the energy potential of available wood supplies for yet another reason, that is., currently available statistics concerning timber harvesting are based on the assumption that only the merchantable bole is used. Thus, current estimates of timber resources could be 30 percent lower than actual reserves. 2

Although supplies vary among regions of the country, no one area appears to face a shortage. Exhibit VI-2 illustrates the energy potential of wood resources in various regions of the country. It is evident from the map that resources are relatively evenly distributed in the Northeast, Southeast, Appalachian, Pacific, and Mountain regions. The Delta and Lakes regions have a somewhat smaller potential, while supplies are most limited in the Northern Plains, Corn Belt, and Southern Plains.

In evaluating the adequacy of wood supplied one should consider the total numbers of households which can be expected to utilize the resource. Generally speaking, major population centers of the United States coincide with those regions which exhibit the greatest potential. fuelwood supply. Even where supplies are lowest, for example in the central part of the country, U.S.D.A. figures show that annual qrowth exceeds annual removals. Thus, it does not appear that any one region will experience shortages.

$1 \quad$ Paul Bofinger, "Better Forestry Trhough Fuelwood Harvesting," paper presented at the Wood Heating Seminar 2 of the Wood Energy Institute, September 1977, Hartford, Connecticut.

2 New England Federal Regional Council, Energy Reserve Development Task Force, Wood Utilization Work Group, "A Report on the Potential of Wood As An Energy Resource in New England," September, 1977. 


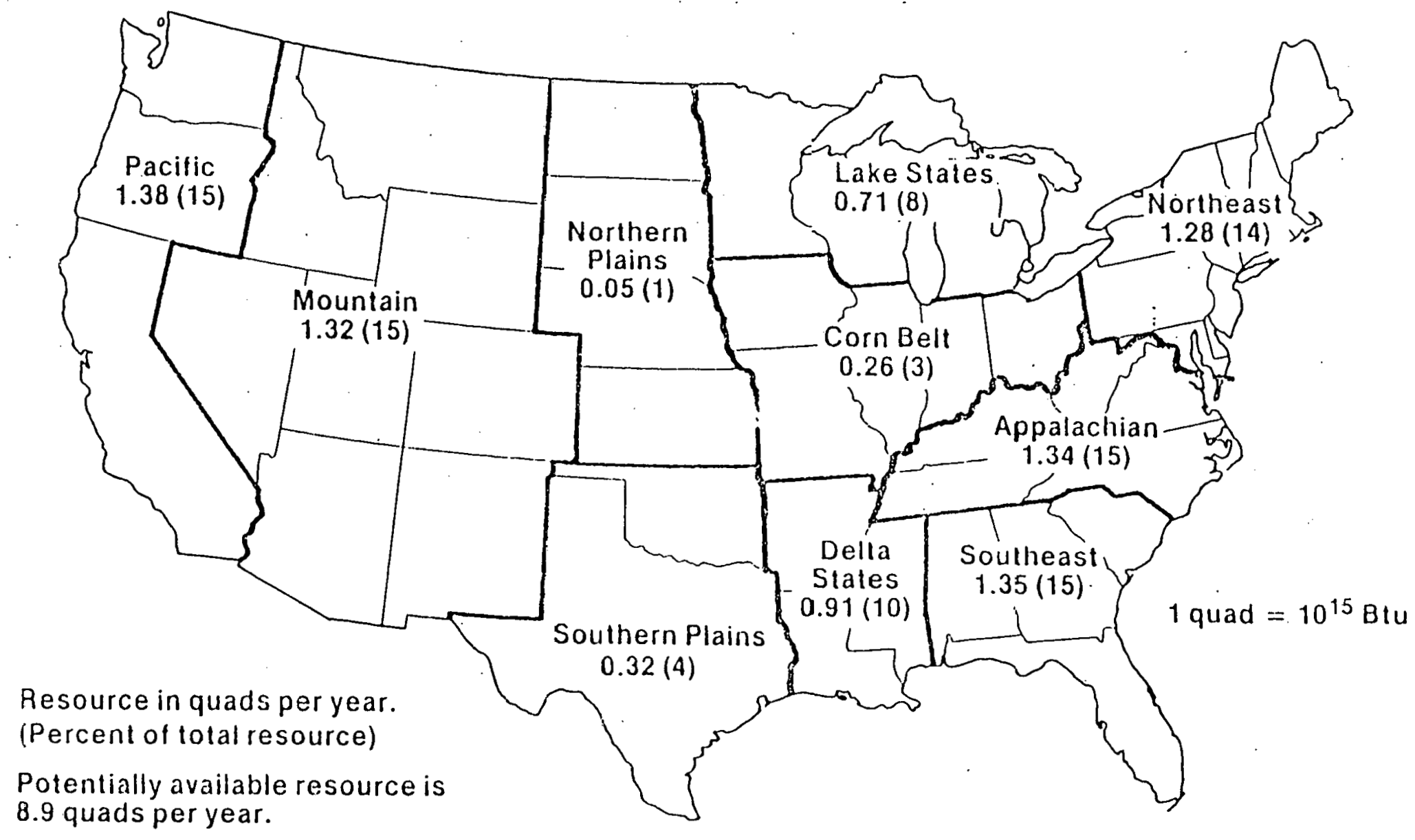

Source: Presentation by Jim Dollard, U.S. Depaztment of Energy, January 11,.1979. 
EXHIBIT VI-3

Wood Utilization

\begin{tabular}{|c|c|c|}
\hline Category of Use & Current Quads/Year & 1990 Quads/Year \\
\hline $\begin{array}{l}\text { Wood Products Industry } \\
\text { - Process Heat/Steam Cogenera- } \\
\text { tion: } \\
\text { About } 45 \text { \% self-sufficient } \\
\text { with use of: } \\
\text { About } 60 \% \text { self-sufficient } \\
\text { with use of: } \\
\text { Residential } \\
\text { - Ese Eor primary and sup- } \\
\text { plementary heating } \\
\text { Utility }\end{array}$ & $\begin{array}{l}0.3 \\
\text { less than } 0.1 \\
1.5\end{array}$ & 0.6 \\
\hline
\end{tabular}

Source: Presentation by Jim Dollard, U.S. Department of Energy, Wood Combustion Workshop, McLean, Virginia, January 11, 1979. 


\section{COMPETING USES OF THE FUELWOOD SUPPLY SHOULD BE RECOGNIZED}

While the overall supply of wood for residential fuel purposes is more than adequate, it is important to recognize that wood is being used more widely for a variety of purposes and that these uses will place additional demands on supplies in the future. Exhibit VI-3 summarizes present and future wood utilization by three categories of uses: use by the wood products industry, residential use, and use by utilities. It is evident from the table that increased utilization could, result in an increased demand of 3.9 quads. Another estimate has suggested residential could be up to 1 to 1.5 quads by 1985 rather than the 0.6 quads presented on Exhibit VI-I. Even assuming this additional use, however, overall demand for wood is well below the supply of 9 quads per year mentioned above.

3. THE ADEQUACY OF THE FUELWOOD SUPPLY IS FURTHER EVIDENCED BY VARIOUS STATE AND FEDERAL PROGRAMS TO ENCOURAGE ITS USE; IT SHOULD BE RECOGNIZED, HOWEVER, THAT LOCAL SHORTAGES MAY OCCUR

An overview of programs which encourage wood use is presented below. In addition, several examples of potential spot shortages are noted.

\section{(1) A Number of Governmental Agencies Support Increased Fuelwood Use}

Each of the foresters contacted as part of this study agreed that current supplies of wood suitable for use as a fuel are more than adequate to meet considerable increases in residential demand.2 Many of them stated, furthermore, that they welcome increased use because of the positive environmental impacts which result from supervised, regular cutting. Increased use has been indirectly supported by many states and by the U.S. Forest service through programs which make firewood available in state and Federal forests.

In addition to these indirect incentives, several governmental agencies have directly fostered increased

1 Booz, Allen \& Hamilton, rough calculation based on 1970 Census data.

2 George Bourassa, Maine Forest Service; Ted Natti, State Forester, New Hampshire; Stan Warner, Assistant Superintendent of Forests, Virginiä. 
wood burning. The Georgia Forestry Commission, for example, has undertaken a campaign to encourage the burning of fuelwood in homes and in industries. Two mobile units equipped with modern wood burning devices tour the state, and brochures dealing with wood burning are distributed. 1 The Tennessee Valley Authority (TVA) also is promoting wood. stove use on an experimental basis. In a program undertaken with the North Georgia Electric Membership Corporation (NGEMC), the TVA wiIl provide interest free loans to customers of the NJGEMC who desire to purchase a wood heater. The loans cover the cost of the heater, chimney, and installation. A final example of governmental encouragement of wood burning is a program in the state of. Idaho which grants tax credits for certain wood burning equipment.

Despite the Large Quantities of Wood Available, Spot Shortages May Occur

Localized shortages of fuelwood are likely to. occur in some areas of the country, even where overall supplies on a regional level are adequate. Several state forests in Idaho, for example, are reported to have suffered from excessive irirewood gathering. In New Hampshire, furthermore, the demand for state permits to gather firewood from state forests is four times the maximum permit supply set by the Division of Forestry.

Another type of shortage may occur in urban areas. While overall timber supplies are plentiful in many regions of the country, supplies are not generally located in close proximity to major cities. As a result, urban dwelling wood users often rely on commercial firewood distributors rather than harvesting their own wood. The costs of this wood are high, however, reflecting the transportation costs of the merchant. Thus, while there is no shortage of wood in an absolute sense, there may be a scarcity of wood at a price that is competitive with other fuels.

I. Descriptions of the Georgia and TVA programs are given in W.E.I. Reports, Vol. 1, No. 2, November, 1978, Wood Energy Institute, Box 800, Camden, Maine, pp. 4-5. 
4. ALTHOUGH THE OVERALL SUPPLY OF FUELWOOD IS LARGE, ONE CANINOT ASSUME THAT THE TOTAL AMOUNT WILL BE IMMEDIATELY AVAILABLE FOR FUELWOOD USE

The ultimate availability of wood depends on the accessibility and location of stands, the numbers and types of owners, and the willingness of owners to harvest. These factors will pose considerable obstacles to full utilization of fuelwood supplies in some cases.

Where the number of owners of forested land is high, for example, large scale fuelwood commercialization efforts could meet considerable contract and administrative burdens. Furthermore, not all owners of timber supplies desire to harvest wood. . In southern New England, for example, 87 percent of the owners of forested land have never harvested timber from their property. The major reasons for this reluctance are fear of destroying scenery, belief that the timber stand is immature or not sufficiently large, distrust of loggers, and fear that harvesting will destroy the land for hunting and wildlife.l clearly, therefore, it will be necessary to convince owners that increased cutting is beneficial to the appearance and productivity of the forest.

5. IN CONCLUSION, POTENTIAL SUPPLIES OF FUELWOOD IN THIS COUNTRY ARE VAST, AND IVITH PROPER MANAGEMENT APPEAR CAPABLE OF MEETING THE PROBABLE INCREASES IN RESIDENTIAL DEMAND FOR WOOD AS AN ENERGY SOURCE

The supply of fuelwood in the United States exhibits two unique and very attractive attributes. First, it is an enormously large supply, and secondly, it is self renerving. The stock is sufficient to meet very large increases in demand solely by relying on excess growth and residues from commercial forestry operations. In addition to current supplies, moreover, a vast potential can be realized through tree farms and enhanced forest management. It should be stressed, however, that the distribution system of wood is not yet developed, and that significant obstacles may block full utilization of the wood resource in the near term.

I New England and Federal Regional Council Energy Resource Development Task Force, Wood Utilization Group, "A Report on the Potential of Wood As An Energy Resource in New England," Federal Energy Administration, Boston, Mass., 1977, p. 16. 
VII. BALANCE OF PAYMENTS IMPACTS 
VII. BALANCE OF PAYMENTS IMPACTS

One of the primary objectives of the federal government energy tax credit program is to help improve the United States' balance of payments position by decreasing the amount of oil imported. A major concern related to tax credits for residential wood burning equipment was that the potential oil revenue savings might be partially or even significantly offset by increased imports of stoves. The purpose of this chapter is to discuss these factors and present an overview assessment of the likely impacts that increased wood heating equipment sales could have on balance of payments. It should be noted that this assessment relied on the best available information and opinions, and did not incorporate any econometric modeling.

1. TAX CREDITS ON WOOD HEATING EQUIPMENT ARE NOT EXPECTED TO SIGNIF ICANTLY INCREASE THE RATIO OF IMPORTED UNITS TO DOMESTIC PRODUCTION

Initial conversations with industry experts indicated that there were three main factors that could potentially influence the ratio of imported units to domestic production:

- Current domestic industry capacity

- Ability of domestic industry to rapidly increase capacity

- Ability of imported products to meet proposed performance and safety standards.

(1) The Portion of the Domestic Industry Producing Cast Iron Stoves, Currently Has Substantial Excess Capacity

As reported in the International Trade Commission's study, "Cast Iron Stoves," I U.S. producers of cast iron

$1 \quad$ U.S. International Trade Commission, "Cast Iron Stoves," Report to the President on Investigation No, TA-201-24 under section 201 of the Trade Act of 1974, wasinington, DC, July 1977. 
Franklin, radiant heater, and other style stoves were operating at an average of about 50 percent of plant capacity as of early 1974, 1975, and 1976. Updated capacity and production data, based on personal communications with industry representatives, indicates that despite a large sales increase in 1977, 197.8 was not a good year and sales dropped. As a result, plant capacity factors are now well below 50 percent. Exhibit VII-l presents these production capacity and utilization figures for the last seven years.

The primary cause of this excess capacity according to industry sources, has been the erosion of the market for domestically produced cast iron equipment and the substitution of less expensive imported units, primarily from Taiwan and Korea. The influx of Asian imports has been increasing over the last five years and as a result, three American foundries specializing in cast iron stoves have either been closed down or have gone bankrupt. ${ }^{2}$

(2) The Portion of the Domestic Industry Producing Fabricated Stoves Has the Ability to substantially Increase Capacity on Very Short Notice

Due to the relative simplicity of construction, it is possible for small manufacturing facilities for plate-type radiant heater stoves to set up in a matter of weeks. The major manufacturers of this type of product, through franchise arrangements, have already established dozens of manufacturing plants across the U.S. and as a result have reached an annual sales level of over one quarter million in five years. Members of this industry segment have stated in conversations with Booz, Allen staff, that they feel that they will be able to continue this rapid growth and would have no significant difficulty in meeting increased demands resulting from the proposed tax credit program.

2 Personal communications. Pauline Dunckel, stove industry consultant. 
EXHIBIT VII-1

Aggregate Plant Capacity for Major U.S. Producers
of Cast Iron. Stoves

\begin{tabular}{|llllllll|}
\hline & \multicolumn{8}{c|}{ (000's) } \\
& 1972 & 1973 & 1974 & 1975 & 1976 & 1977 & 1978 \\
\hline \hline Actual Production & 109 & 132 & 164 & 248 & 129 & 207 & 129 \\
Plant Capacity (Annual Basis) & 262 & 305 & 366 & 442 & 438 & $425 \star$ & $425^{*}$ \\
Capacity Utilization \% & $42 \%$ & $43 \%$ & $45 \%$ & $56 \%$ & $29 \%$ & $49 \%$ & $28 \%$ \\
\hline
\end{tabular}

* Estimated

SOURCES:

1 Data for 1974, 1975 and 1976 is based on "Cast Iron Stoves," a report prepared by the U.S. International Trade. Commission, July 1977.

2 Data for 1977 and 1978 is based on personal communications with Mrs. Pauline Dunckel, Consultant for selected stove manufacturers. 
(3) If Tax Credits For Wood Heating Are Implemented With Rigorous Safety and Performance Standards, The Wood Stove Industry Will Be Increasingly Segmented Into Two Distinct Parts

These two segments are:

- Higher performance units, moderately or high priced, primarily for people seeking to provide a substantial portion of their heat with wood. For these units, which likely could meet proposed performance and safety standards for tax credit eligibility, tax credits of 15 or 30 percent would lower the initial purchase price and provide a significant promotional advantage..

- Lower performance units, low or moderately priced for occasional or emergency heating. Many of the lower priced models which include nearly three-quarters of the foreign products currently appear to be in this category and could be excluded from tax credit eligibility if safety and performance standards are required.

(4) Based on the Information Available, The Current Ratio of Imported Units to Domestically Produced Units Should Not Be Significantly Changed with A Tax Credit

- There is substantial excess capacity already available in the industry segment producing cast iron stoves. This capacity alone is approximately 200,000 units per year and exceeds the probable incremental demand due to tax credits. 3

- Addition of increased capacity can be accomplished on a short time frame in the industry segment producing fabricated stoves.

3 Refer to Exhibit III-1 for incremental demand data. 
- The domestic industry is strongest in the market for moderate and high performance stoves, and would be in a good position to meet safety and performance standards.

2. THE REDUCED FOREIGN OIL IMPORTS SHOULD HAVE A MUCH GREATER IMPACT ON THE BALANCE OF PAYMENTS THAN THE INCREASED WOOD HEATING EQUIPMENT IMPORTS

Airtight wood burning stoves and furnaces can save from 10 to $20 \mathrm{bbl}$ oil equivalent over a 20-year lifetime per unit. The accumulated oil savings during this time period far outweigh the impact of increased wood heater imports on the balance of payments.

(1) The Initial Price of the Wood stove Is Quickly Recovered In Terms of Imported Oil Savings

The preceding section indicated that imported stove sales may increase slightly as a result of the tax credit. However, even if all the incremental sales induced by the tax credit were imported units, the annual savings in imported oil would soon offset the purchase price of the wood stove unit. For example, an imported, efficient, airtight wood stove sells for slightly more than the domestic $\$ 500$ average price. At $10 \mathrm{bbl}$ oil equivalent saved per year, each stove unit will save $\$ 140$ in imported oil per year when valued at $\$ 14$ per bbl. Thus, in about four years, the stove unit will have offset the initial $\$ 500$ to $\$ 600$ average price.

(2) During The Remainder of Its Twenty Year Life,

Each Stove or Furnace Will Continue To Save $\$ 140$ to $\$ 280$ Per Year Improving the Balance Of Payments

Since an airtight wood stove saves about $10 \mathrm{bbl}$, oil equivalent per year over a lifetime of 20 -years and a wood burning furnace saves nearly 20 bbl oil equivalent, over the 20-year period, these units will each save from 200 to $400 \mathrm{bbl}$ oil equivalent. Valued at $\$ 14$ per bbl, this amounts to $\$ 2,800$ to $\$ 5,600$ in 
imported oil savings over 20 years or 5 to 10 times the initial purchase price of the wood stove or furnace. 4 This results in a favorable long run impact on the balance of payments.

3. TAX CREDITS ON WOOD BURNING EQUIPMENT WILL NOT ADVERSELY AFFECT THE BALANCE OF PAYMENTS

The ratio of imported to domestic units that could qualify for tax credit eligibility should not significantly change, if tax credits for stoves become available.

Even if in the first years of tax credit eligibility, imported unit sales did rise somewhat, the long run value of fossil fuel savings (i.e., over a 20-year lifetime of a stove) should far exceed the initial cost.

4 In accordance with DOE policy, equivalent oil savings are assumed to reduce oil imports proportionally. In fact, a somewhat less than proportional import reduction is more reasonable which would decrease the magnitude of these results but not the overall interpretation. 


\section{CONSUMER ECONOMICS}

From a consumer's standpoint, economics of wood burning is a major factor in deciding whether or not to consider wood as a source of fuel. From a government perspective, however, it is important as an indicator of the effect tax credits will have on the attractiveness of this alternate energy source to consumers. In order to effectively evaluate the consumer economics of wood burning and the effect of tax incentives on consumer economics, three major areas are examined in this chapter:

- Effect of fuel wood cost and wood equipment . efficiency on wood heating economics

- Effect of equipment, maintenance and fuel cost on the life cycle cost of wood heating

- Effect of tax credits on wood heating economics.

1. EFFECT ON FUEL WOOD COST AND WOOD BURNER EFFICIENCY ON WOOD HEATING ECCNOMICS

The first consideration in evaluating the economics of wood heating is a comparison of wood fuel costs to conventional heating fuel costs.

(1) Where Cord Wood Is Purchased At Market Prices, wood Fuel Is Competitive With Fuel Oil or Electric Heat Pump Heating

At reasonable levels of efficiency for an airtight wood stove (i.e., 50 percent) and equivalent wood fuel costs of $\$ 60 /$ cord wood, heating can compete with fuel oil at $50 \mathrm{c}$ per gallon and electric heat pumps at $4.0 \mathrm{C}$ per kWh. Exhibit VIII-l can be used to determine the break even energy prices for other wood fuel costs. (Note: This exhibit includes fuel costs only.) 
- Where less efficient equipment is used such as conventional fireplaces or non-airtight stoves, wood heating with purchased fuel is generaliy not economically competitive with conventional fuels except possibly with electric resistance heat. Exhibit VIII-I also shows a 30 percent efficient wood. burning unit, which at $\$ 60$ per cord of wood fuel becomes comparatively uneconomic.

- Wood heating cannot generally compete with natural gas but may be able to compete with propane fuel, commonly used in rural areas.

(2) Currently A Significant Number of Wood Burners Cut Their Own Firewood and in This Case, Wood Heating Has $\bar{A}$ Definite Economic Advantage Over Conventional Home Heating Fuels

Based on statewide surveys conducted in Maine, Vermont and New Hampshire, well over 50 percent of all residential wood users cut ail or apparently part of their own firewood supply. $1,2,3$ In New England, the majority of owner-cut wood comes from the cutter's own land or that of friends. In regions with large state or national forests, significant amounts are also cut by permit holders.

As a result, where wood is either free or cut by the user at a nominal cost, the initial cost for wood heating equipment can often be recovered within one or two years assuming wood provides a significant portion of a home's heating requirements. For individuals who believe the cost for fuel wood is based on their own "free" labor, wood heating has a definite economic advantage over conventional home heating fuels.

1 Dalton, M.M., et al, "Household Fuel Wood Use and Procurement in New Hampshire," University of New Hampshire, October 1977.

2 Swain, E., "Maine Fuel Wood Study," Maine Audobon Society, November 1978 .

3 Action Research, Inc., "Use of Wood As a Heat Source and Quality of Insulation in Vermont Households," Burlington, Vermont, June 1978 . 
2. EFFECT OF EQUIPMENT, MAINTENANCE AND FUEL COST ON THE LIFE CYCLE COST OF WOOD HEATING

Although wood burning is often compared to conventional home heating based on fuel cost alone, the full cost also includes amortization of incremental equipment cost plus any outlays for replacement parts or service calls. Each of these factors are discussed in the sections that follow.

(1) The Primary Factor in Wood Heating Iife Cycle Economics Is the Fuel Wood Costs

Depending on the type of equipment and the wood usage, fuel costs typically account for two-thirds to four-fifths of the annual owning and operating cost for wood heating equipment. Annualized costs of several types of wood heating systems are given in Exhibit VIII-2.

One type of system which is shown in the exhibit is a retrofitted wood burning stove supplementing an electric heat resistance heating system. Installed costs for this type of wood burning equipment are assumed to be $\$ 500$ for the stove and $\$ 300$ for a new prefabricated metal chimney for a total of $\$ 800$ (line g). The annual amortized cost over a 20-year lifetime at a 10 percent interest rate would be $\$ 94$ per year (Iine $h$ ). At a typical wood usage of 4 cords per year and $\$ 60$ per cord, (adjusted for 6 percent compound inflation rate over a 20-year period) the average annualized fule cost is $\$ 468$ per year ( 1 ine $k$ ). When maintenance is included (i.e., chimney clean once a year), wood fuel costs accounts for 75 percent of the $\$ 621(h+k+m)$ total annual costs.

(2) The Second Factor in Wood Heating Economics Is Equipment Amortization Costs

Again referring to Exhibit VIII-2, annual wood burning equipment amortization costs (h) are typically 10 percent of the total annual wood heating cost $(\mathrm{h}+\mathrm{k}+\mathrm{m})$. For a small stove that requires no new chimney, this may amount to only $\$ 30$ per year, but for large central systems, equipment costs can be many times this amount. 
(3) The Third Factor in wood Heating Economics Is Maintenance Costs

Normally maintenance costs for wood burning equipment are small compared to fuel costs. The most common maintenance item is chimney cleaning. Typically, it is done once or twice a year, depending on usage, and costs $\$ 20$ to $\$ 30$ per cleaning if a chimney sweeping service is used.

(4) The Comparative Consumer Economics of Wood Burning Will Be Significantly Affected By The Changing Prices of Conventional Fuels

Since fuel prices comprise the largest annual. heating cost for all heating systems, the relative changes in the price of fuel will significantly effect the economics of heating. Calculations in Exhibit VIII-2, rather than assuming a stable cost of. Iuel, have assumed the following changes in the price of fuel over a 20-year period.

- Price of oil assumed to rise at an average rate of 10 percent per year

- Price of electricity is assumed to rise at an average rate of 8 percent per year

- Price of gas, due to its expected dereguiation, is assumed to rise at an annual rate of 12 percent per year

- The price of fuel wood is assumed to grow at an annual rate of 6 percent per year.

The conclusion from this analysis is that although wood heating is marginally competitive at current fuel prices, when escalating electric, oil and gas rates are taken into account, wood heating becomes economic with oil heat and heat pumps. Refer to Exhibit VIII-2 (1ines $f$ and $o$ ) for further detail. 
EXHIBIT VIII-I

Wood Heating Fuel Cost Comparison

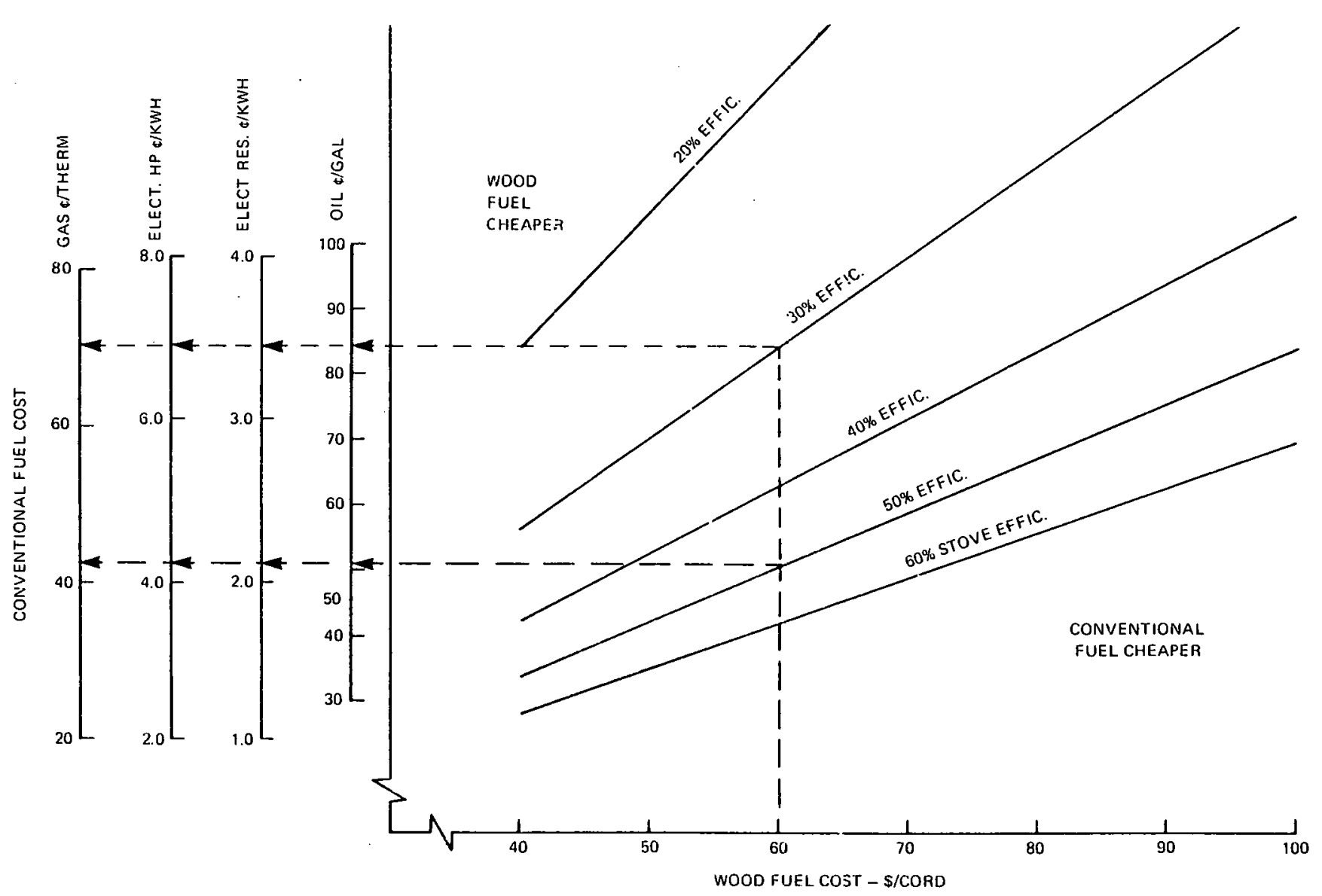

FOOTNOTHS:

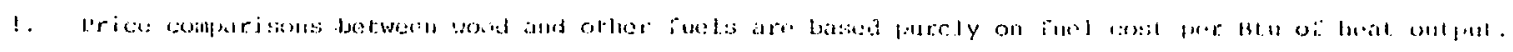

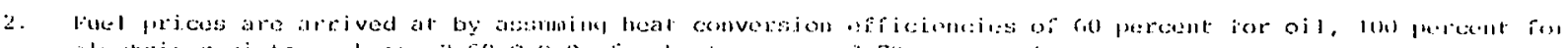

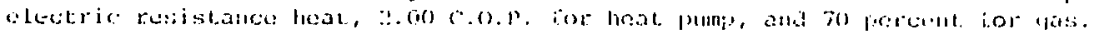


EXHIBIT VIII-2

Annualized Costs for Selected Residential Wood Heating systems

\begin{tabular}{|c|c|c|c|c|c|c|c|}
\hline & Cost Component & $\begin{array}{l}\text { Retrofitted } \\
\text { Woodburning } \\
\text { Stove } \\
\text { Supplementing } \\
\text { 0il-Fired } \\
\text { Boiler }\end{array}$ & $\begin{array}{l}\text { Dual-Fuel } \\
\text { Wood/0il } \\
\text { Fired } \\
\text { Furnace } \\
\text { (New House) }\end{array}$ & $\begin{array}{l}\text { Retrofilted } \\
\text { Hoodburning } \\
\text { Stove } \\
\text { Supplentiventing } \\
\text { Clectric } \\
\text { Resistance Heat }\end{array}$ & $\begin{array}{c}\text { Retrofitted } \\
\text { Woodburniny } \\
\text { Stove } \\
\text { Supplementing } \\
\text { Electric } \\
\text { Heat Pump }\end{array}$ & $\begin{array}{c}\text { Retrofitted } \\
\text { Woodburning } \\
\text { Stove } \\
\text { Suppleilent ing } \\
\text { Gas Furnace }\end{array}$ & $\begin{array}{l}\text { Woodburning } \\
\text { Stoves Supply } \\
100: \text { of Heat } \\
\text { Dewand. } \\
\text { (Now llouse, } \\
2 \text { Stuves and } \\
2 \text { Chimineys) }\end{array}$ \\
\hline a & $\begin{array}{l}\text { INITIAL CONVENTIONAL EQUIPMENT COST } \\
\text { INCLUDING INSTALLATION }\end{array}$ & $\$ 3,500$ & $\$ 3,500$ & $\$ 1,500$ & $\$ 5,000$ & $\$ 3,000$ & -0 \\
\hline b & ANNUAL EQUIPMENT AMORTIZATION COST ${ }^{2}$ & $\$ 410$ & $\hat{\$} \quad 410$ & $\$ 176$ & $\$ 585$ & $\$ 351$ & $-0-$ \\
\hline c & ANNUAL IZED MAINTENANCE EXPENSE ${ }^{3}$ & $\$ 98$ & $\$ 98$ & $-0-$ & $\$ 195$ & $\$ 59$ & $-0-$ \\
\hline d & ANNUAL CONVENTIONAL FUEL USE ${ }^{4}$ & $1,200 \mathrm{gal}$. & 1,200 gal. & $29,600 \mathrm{kWh}$ & $14,800 \mathrm{kWh}$ & 1,440 therus & $-0-$ \\
\hline e & ANGUALIZEO CONVENTIONAL FUEL COST $^{5}$ & $\$ 1,980$ & $\$ 1,980$ & $\$ 3.433$ & $\$ 1,716$ & $\$ 1,450$ & $-0-$ \\
\hline$f$ & $\begin{array}{l}\text { TOTAL ANNUAL CONVENTIONAL HEATING } \\
\text { SYSTEIA COST } \$ / Y R .(f=b+c+e)\end{array}$ & $\$ 2,488$ & $\$ 2,488$ & $\$ 3,609$ & $\$ 2,496$ & $\$ 1,860$ & $-0-$ \\
\hline g & $\begin{array}{l}\text { INITIAL INCREMENTAL COST FOR WOOD } \\
\text { IIEATING EQUPPHENT }\end{array}$ & $\$ 500$ & $\$ 1,000$ & $\$ 800$ & $\$ 800$ & $\$ 800$ & $\$ 1,600$ \\
\hline h & ANNLAL EQUIPMENT AMORTIZATION COST & $\$ 59$ & $\$ 117$ & $\$ 94$ & $\$ 94$ & 94 & $\$ 187$ \\
\hline $\mathbf{i}$ & PEERCENT OF HEAT SUPPLIED BY WOOD & $33 \%$ & $66 \%$ & $33 \%$ & $33 \%$ & $33 \%$ & $100 \%$ \\
\hline $\mathrm{j}$ & HOOL FUEL USE-COROS/YEAR ${ }^{7}$ & 4 & 8 & 4 & 4 & 4 & 12 \\
\hline$k$ & ANNUALIZED WOOD FUEL $\operatorname{cosT}^{8}$ & $\$ 468$ & $\$ 936$ & $\$ 468$ & $\$ 468$ & $\$ 468$ & $\$ 1,404$ \\
\hline 1 & CONVENTIONAL FUEL SAVING PER YEAR. & $\$ 660$ & $\$ 1,320$ & $\$ 1,144$ & $\$ 572$ & $\$ 483$ & NiA \\
\hline$m$ & ANNUAL IZED CIIIMNEY CLEANING EXPENSE ${ }^{9}$ & $\$ 59$ & $\$ 111$ & $\$ 59$ & $\$ 59$ & $\$ \quad 59$ & $\$ 175$ \\
\hline $\mathrm{n}$ & $\begin{array}{l}\text { NET ANNUAL COST (SAVING) DIFFERENTIAL } \\
\text { FOR WOOD HEATING }\end{array}$ & $(\$ \quad 74)$ & $(\$ 150)$ & $\left(\begin{array}{ll}(\$ 523\end{array}\right)$ & $\$ 49$ & $\$ 138$ & Nin \\
\hline 0 & $\begin{array}{l}\text { TOTAL ANNUAL WOOD HEATING SYSTEH COST } \\
(0=f+h+k-1+m)\end{array}$ & $\$ 2,414$ & $\$ 2,338$ & $\$ 3,028$ & $\$ 2,545$ & $\$ 1,998$ & $\$ 1,776$ \\
\hline$p$ & $\begin{array}{l}\text { EFFECT OF SOLAR TAX CREDIT (30\%) } \\
\text { ON HOOD HEATING COST }\end{array}$ & $(\$ 18)$ & $(\$ 35)$ & $(\$ 28)$ & $(\$ 28)$ & $\left(\begin{array}{ll}\$ & 28\end{array}\right)$ & $(\$ \quad 56)$ \\
\hline$q$ & $\begin{array}{l}\text { NET ANNUAL COST WITH SOLAR TAX CREDIT } \\
(q+0-p)\end{array}$ & $\$ 2,396$ & $\$ 2,303$ & $\$ 3.000$ & $\$ 2,517$ & $\$ 1,970$ & $\$ 1.720$ \\
\hline
\end{tabular}

FOOTMOTES:

1. Initial conventional equipment cost, includes instaliation and distribution systells.

2. Discount rate of $10 x$ and 20 -year equipment lifetime assumed.

4. Maintenance expense is escalated at a rate of 6\% per year.

pump. Total heat demanded by the household is estimated to be 100 million Btu/year, based on 5000 degree days.

5. Energy prices assumed to be 554 per gallon of oil escalated at $10 \%$ over a 20 -year period.

$25 \notin$ per therm of gas escalated at $12 \%$ over a 20 -year period

6. Hoodburning systell cost is generally assuned to be $\$ 800$. Of that $\$ 500$ is for the woodburning stove and $\$ 300$ for the chimney. All installation costs are included.

7. Heat conversion efficiency of wood stoves is assumed to be $50 \%$.

8. Wood fuel cost assumied to be $\$ 60$ per cord, escalated at $6 \%$ over a 20 -year period.

9. Assulned to be $\$ 30 /$ per 4 -cord/year wood consumption escalated at $6 \%$ over a 20 -year pericd. 
(5)" There Are A Number of "Hidden" Costs For Wood Heating That Cannot Be Accurately Quantified But Have A Considerable Effect on Economics From A Consumer's Standpoint

The major hidden cost for home wood heating involves the time required for loading of wood and tending the equipment. At one-fourth hour per day, a labor rate of $\$ 4$ per hour and a 120-day heating season, the labor for equipment operation is worth $\$ 120$ a year. 4

Other hidden costs include:

- Ash removal once a week

- Dry storage space for fuel such as a shed or garage area

- Smoke detector

- Higher homeowner insurance rates in some circumstances.

(6) There Are A Number of Consumer Benefits For Wood Heating That Are Often Overlooked

- In a new home where one or two stoves will be the primary heat source, the backup heating system can often be reduced in size and simplified. This can significantly improve wood heating economics as shown in Column 6 of Exhibit VIII-2.

- Properly sequenced wood heating systems can also be used to moderate winter demand profiles for electric and gas utilities.

- Wood heating can help insure against fuel delivery interruptions and power blackouts.

4 Additional discussions of wood heating economics are given in Garrett, D., "Economic Implications of Using wood Space Heaters for Home Comfort Heat," Northeastern Forest Experiment Station, Burlington, Vermont, April 1978; ard Shelton, Jr. and Shapiro, A., The Woodburners Encyclopedia, Chapter 13, Vermont Crossroads Press, 1976. 
3. EFFECT OF TAX CREDITS ON WOOD HEATING ECONOMICS

(1) In Terms of the Overall Effect on Wood Heating Economics, Equipment Tax Credits Will Have a Small But Positive Impact on Annual Heating Costs

The key reason for this conclusion is that for most wood burners purchasing wood, the major ongoing cost factor is fuel rather than equipment. The marginal benefits of even a 30 percent tax credit when amortized over a typical equipment lifetime of 20 years, decreases the total annual heating costs by less than 5 percent. The bottom lines of Exhibit VIII-2 show the effect of sales tax credits on six typical wood heating system combinations.

(2) Tax Credits Will Have A Significant Effect on Wood Heating Economics in Cases Where the Fuel Wood Cost Is Negligible or Ignored

As shown in Exhibit VIII-2, the annual cost of wood is two-thirds to four-fifths of the total wood heating costs. For those wood burners who are able to utilize a free source of wood, the tax incentives may appear to have a greater economic impact, although the actual cash value of the tax benefits remain constant.

(3) Additional Effect of Wood Heating Tax Credits

The active support of wood burning by the federal government, through such actions as tax credits, should have a considerable promotional effect on wood burning. Tax credits will likely be a major factor influencing consumer behavior in terms of purchasing wood heating equipment. 
IX. EMPLOYMENT AND OTHER SOCIAL IMPACTS 
IX. EMPLOYMENT AND OTHER SOCIAL IMPACTS

Tax incentives to encourage increased residential wood burning could have significant social impacts. While some of these implications are more obvious than others, all deserve consideration by DOE in its assessment of tax credit policy options.

Several types of social impacts are discussed in this chapter and are divided into two categories: employment impacts and other social impacts. The discussion is necessarily brief due to the limited research on the subject.

\section{EMPLOYMENT IMPACTS}

It appears that increased residential fuelwood use could have significant effects on local employment, but research is insufficient to predict the magnitude of national level impacts. Studies that have addressed the employment issue are discussed below.

(1) Limited Research Suggests That Increased Utilization of Firewood Will likely Have Positive Regional Employment Benefits

Two studies on wood energy potential which were completed in the past two yearsl concluded that increased wood usage will benefit local economies and employment primarily by increasing the demand for firewood. One of these research efforts, conducted by Brookhaven National Labs, suggested that between 10,000 and 16,500 jobs could be created in New England as a result of increased wood use by residential and small commercial operations in that region. Another study prepared for the state of Vermont is consistent with the Brookhaven

$1 \quad$ National Center For Analysis of Energy Systems, Brookhaven National Laboratory Associated Universities, Inc, Assessing The Employment Implications of Alternative Energy Supply, Conversion, and End Use Technological Configurations: The Case of Firewood Versus Fuel oil In New England in 1985. February, 1978 and Governor's Task Force on Wood as a Source of Energy, State of Vermont, Final Report, August, 1975. 
estimate. The Vermont study suggests that by 1985 the wood energy industry in that state could employ up to 3,500 people.

While the assumptions underlying the Vermont estimate were not made explicit, those inherent in the Brookhaven report were discussed in some detail. The most important of these assumptions are noted below.

- The Brookhaven study estimated only direct employment impacts in New England for an assumed substitution of firewood for fuel oil. The study focused on direct employment impacts associated with firewood cutting and transportation. It did not consider secondary impacts such as increased employment in the wood stove industry, or tertiary impacts such as a greater demand for steel and consequent stimulation of employment in the steel industry.

The Brookhaven study, furthermore, made a number of assumptions concerning fuel wood use and the time necessary to cut and distribute wood. Any prediction of employment impacts must be based necessarily on a number of assumptions. These include the following:

- The total amount of wood that will be substituted for conventional fuels

- The extent to which users cut their own wood

- The time necessary to cut, load, and transport the wood to consumers

- The time necessary to supply equivalent amounts of substituted fuel to users.

The Brookhaven study assumed that 0.1 quads of wood could be substituted for fuel oil in New England in 1985. Of this amount, .05 to .074 quads would be purchased from commercial cutters. The study furthermore estimated that an average of eight hours is required to cut, gather, and partially split one cord, and that one and one half hours are required for transportation of the same amount. Based on these assumptions, estimates in the following table were obtained. 
Labor Requirements For Wood and Fuel Oil Distribution

\begin{tabular}{|l|c|c|}
\hline \multirow{2}{*}{ Fuel } & Labor Requirements (Man-years/Btu) \\
\cline { 2 - 3 } Wood & Cutting/Pipeline Transport** & Delivery \\
Fuel Oil* & $222.2 \times 10^{-12}$ & $\begin{array}{l}4.7 \times 10^{-12} \\
30 \times 10^{-12}\end{array}$ \\
\hline$* \quad 0.2 \times 10^{-12}$ & $\begin{array}{l}\text { Estimates were taken by Brookhaven from other research by } \\
\text { Bechtel and SRI. } \\
\text { Labor required to move a Btu of fuel from a tanker through } \\
\text { a 300 mile pipeline to storage facilities. It does not } \\
\text { appear that this estimate includes production labor. }\end{array}$ \\
\hline
\end{tabular}

Applying these labor coefficients, Brookhaven obtained the range of 10,200 to 16,500 jobs in New England. This represents the increase of direct labor stemming from wood use minus the labor lost from the substitution of wood for fuel oil. It is clear from the table that wood fuel supply and distribution operations are significantly more labor intensive than fuel oil operations.

$$
\begin{aligned}
& \text { More Detailed Research Is Needed to Predict } \\
& \text { Employment Impacts on a National Level }
\end{aligned}
$$

While the Brookhaven and Vermont studies clearly suggest the beneficial employment impacts of increased wood use, these figures can not necessarily be extrapolated to a national level. The Brookhaven study, for example, is careful to note that the analysis is limited to direct employment impacts. One should recognize, furthermore, that the study considers New England only. The availability and use of fuel wood will vary in different regions, and thus employment in each region should be considered separately.

Secondary and tertiary, impacts of increased wood use could be significant, and thus deserve greater attention. If wood stoves are produced in the United States, for example, new jobs in the wood stove industry could result. Possible impacts on the steel industry and other tertiary effects should also be studied. 
While research on the employment impacts of wood use is sparce, discussions of other social impacts are virtually nonexistent. Although no conclusive findings can be noted, it is possible to raise a number of issues for consideration. Several of these are discussed below.

(1) Tax Credits for Wood Burning Equipment Could Benefit Lower Income Persons As Well As Moderate and High Income Individuals

Individuals who burn wood represent a very heterogenous group. While many low income persons are known to burn fuel wood, there is also a trend in some areas of the country for well educated, higher income persons to convert to wood burning stoves and furnaces. I Tax credits for wood burning equipment would stimulate wood use by each of these groups, but most importantly it would made wood heating affordable to lower income persons. Similar advantages do not result from credits for other technologies that are currently eligible; solar and other alternatives provide little help to lower income persons because the initial costs of these systems are prohibitively high.

(2) Tax Credits Could Ease the Energy Cost Burden of Lower Income Families in Some Parts of the country

Related to the first point above, if the initial cost of wood burning equipment is more economically attractive to lower income families, more may convert to wood as a primary fuel. Where low income persons can cut their own wood supply, fuel expenses could be decreased significantly, allowing more disposal income to be alloted to food, clothing, and other necessities.

\section{(3) Tax Credits May Not Be Geographically Equitable}

Conversion to wood as a primary fuel, even with the incentive of tax credits, will not be practical for all persons in all areas of the country. In fact,

$\bar{I} \quad$ One survey of wood users in Maine found that individuals who burn wood have higher levels of education and considerably higher incomes than those who do not burn wood. Maine Audubon Society, Final Report: Maine Firewood Study, November 14, 1978. 
it is most likely that the overall number of users will be small and that they will be located in relatively isolated areas. Thus, conversion is not a viable option for some families, and the tax credit for wood burning equipment will therefore benefit users most where wood can be obtained easily at a competitive cost. These conditions will most likely be met in rural rather than urban areas.

(4) Tax Credits May Help Foster an Attitude of Energy Self-Sufficiency and Conservation

Even if conversion to wood burning equipment is neither uniform nor widespread, incentives could help foster a national philosophy of energy self-sufficiency. Wood burning provides an opportunity for individuals to be self-reliant in a manner that few other technologies offer. As noted above, these opportunities are available to individuals in a wide spectrum of income brackets. 
EXHIBIT

Alternat-ve Policy Options and Suboptions
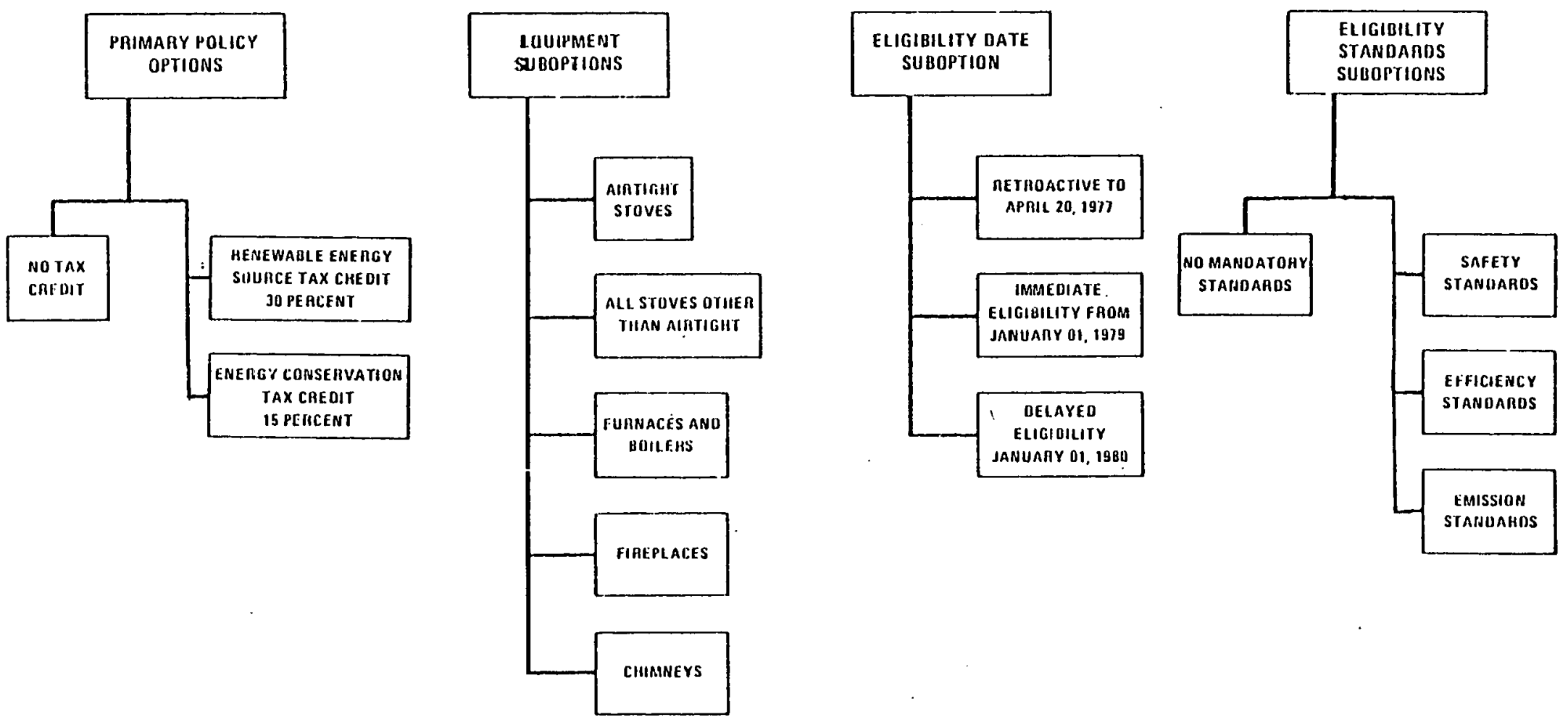


\section{DOE POLICY OPTIONS}

As stated in the Introduction, the overall goal of this report is to assemble the essential information and facts which will enable the Department of Energy to recommend the inclusion or exclusion of residential wood burning equipment in the energy tax credit program for individuals. The policy options open to DOE, however, are more numerous and their assessment far more complex than a simple recommendations for or against tax credits.

For the purposes of this study, the primary pclicy options open to DOE were defined as:

- Option 0 -ivo Tax Credits

- Option I-Renewable Energy Source Tax Credits ( 30 percent)

- Option II-Energy Conservation Tax Credits (15 percent).

Within options I and II, there are a number of suboptions which address the type of equipment, eligibility date and eligibility standards. These suboptions include:

\footnotetext{
Suboption A-Air tight stoves only

Suboption B-All stoves other than airtight units

Suboption C-Furnaces and boilers

Suboption D-Fireplaces

Suboption E-Chimneys and auxiliary equipment

Suboption 1-Retroactive to April 20, 1977

Suboption 2-Immediate eligibility from January 1, 1979

Suboption 3-Delayed eligibility to January 1,1930

- Suboption a-No mandatory standards
} 


$$
\begin{aligned}
& \text { - Suboption b-Safety standards } \\
& \text { - Suboption c-Efficiency standards } \\
& \text { - Suboption d-Emissions standards. }
\end{aligned}
$$

These policy options are displayed on Exhibit $x-1$.

This final chapter of the report will present the key pros and cons for each option based on the results discussed earlier. It will also include a brief description of the option.

\section{OPTION 0 : NO TAX CREDITS}

This option recognizes the fact that residential wood burning use is already expanding rapidly and that Federal government incentives may not be needed to stimulate future growth. This policy option, furthermore, leaves open the possibility of redirecting Federal funds for research, development, demonstration and other support for wood burning development.

\section{Pros :}

- Sales of wood burning equipment already have grown five-fold since the oil embargo, from 200,000 units in 1973, to over one million units in 1978 (refer to Exhibit II-2). Based on this rapid growth, there is a question whether tax incentives are necessary to ensure continued sales growth.

- More time will be available for the completion of the many ongoing government and private efforts in the areas of improved product designs, standards development, environmental impact research, and wood fuel resource assessment. One of the key concerns of previous opponents of wood stove tax credits was that the Federal government's support for this conservation device may be premature due to the many long-range problems needing further research.

- Federal funds could possibly be more effective if spent directly on solving current well-established problems affecting the continued use of wood such as: 
Increased funding for forest management programs

- Training programs for building code inspectors and fire marshals

- Consumer education programs on installation and operational guidelines

Assistance to manufacturers in establishing and complying with standards.

Cons:

- Department of Energy and the Administration in general have been criticized for withholding financial support for an energy resource that it has been otherwise promoting. This criticism was heightened when the final Energy Tax Act of 1978 emerged from the Conference Committee excluding wood burning equipment, after earlier versions had included it.

- The no tax credit option differs from previous federal and state encouragement of accelerated biomass utilization:

A New England Federal Regional Council report in 1977 recommended the promotion of tax incentives for wood burning equipment.

Significant attention has been given to biomass and direct burning of wood, in the Domestic Policy Review on Solar Energy.

TVA has a well publicized demonstration program supplying wood stoves to electric heating customers in North Carolina and Tennessee.

A State of Vermont Governor's Task Force on Wood as a Source of Energy (1975) concluded that positive steps should be taken to encourage wood use in Vermont. 
- The state of Idaho recently provided for state income tax credits for residential wood heating equipment.

- This option may be misinterpreted by some prospective wood burners as suggesting that the Federal Government does not believe wood burning a viable alternate energy source. This misinterpretation may cause some loss in sales.

\section{OPTION I RENEWABLE ENERGY SOURCE TAX CREDIT (30 PERCENT)}

Despite the current surge in wood heating equipment sales, there are a number of reasons for support of residential wood heating equipment tax credits. The first alternative Federal incertive option is the renewable energy source tax credits provision of the NEA. This option provides for a 30 percent credit for the first $\$ 2,000$ of equipment expenditure plus 20 percent of the next $\$ 8,000$ of expenditure. It applies to individuals, is for primary residences only, and is for expenditures in new construction as well as for retrofitted equipment.

\section{Pros:}

- A 30-percent credit should result in a savings of between 240 and 420 million bbl oil equivalent cumulative through the year 2005, depending on the type of equipment eligible. (Refer to Exhibit III-4.)

- The tax credit should improve the nation's balance of payment position by reducing the volume of oil imports.

- The credit should increase sales of residential wood burning equipment by approximately 30 percent.

- With proper standards, tax incentives will allow the government to selectively encourage use of equipment meeting established safety and performance standards.

- Tax incentives will indirectly encourage greater public recognition of the nation's forest resource and may give impetus to better forest management practices. 
- Credits will improve the consumer economics of wood heating for many users (refer to Exhibit VIII-2).

- Renewable energy tax credits eligibility (30 percent) will encourage wood energy usage in new homes as well as for retrofit units. This will significantly increase the size of the potential market for wood burning equipment.

- Local economies and job markets may benefit with increased numbers of equipment dealers and installers, wood fuel distributors, and supplemental services such as chimney sweeping (refer to chapter IX for a further discussion).

- Tax credits will provide an incentive for lower income individuals as well as moderate or high income persons. Various studies have shown considerable use of wood heating by low income individuals and tax incentive for wood stoves would definitely help make wood heating affordable for many more. Solar and other alternative energy tax credits provide little help for low income persons because initial costs for these systems are high.

Cons:

- The net costs to the government in terms of tax revenue loss ranges from a low of $\$ 700$ milition cumulative through 1985 to over $\$ 5$ billion, depending on the type of equipment eligible. This tax revenue loss is several times larger than the estimated loss for solar home tax credits (refer to Chapter III for further details). 
- Tax credits for residential wood burning equipment were originally rejected because of budget limitations and this continues to be a factor since the administration is seeking to reduce the Federal budget deficit. If the 30 percent renewable energy tax credits are. selected at the appropriate level, the tax revenue loss will be even higher than previous tax credit,bills for wood burning equipment which were based on a 20 percent tax credit.

- The tax incentives may accelerate demand for currently available models of equipment at a time when most product lines are undergoing extensive design development. A possible result of premature market stimulation could be to induce manufacturers to invest in production facilities for current models of equipment rather than to continuously develop and market new products.

- Tax incentives may indirectly lead to increased fires in homes. Research on the correlation between the use of wood burning appliances and the occurrence of home fires is underway, but the consequences of widespread wood use in terms of safety is still unknown. Some experts believe the safety issue is well on the way to being resolved while others view it as a major uncertainty.

- The long range environmental impacts are unpredictable at this time although some experts believe that the major deleterious effects are controllable. Considerable new research is underway in the areas of particulate and chemical emissions, but there is very little data so far.

There may be at least some overdemand for firewood at the local level causing higher prices and possibly damage to the forest environment. Although the overall forest resource is large, some areas have reportedly. already suffered from excessive cutting, especially near roads and parks. In addition, some woodlots have had excessive cutting of small trees which, if done on a large scale, could seriously limit the future stock of mature timber (i.e., in 20 years). 
3. OPTION II: ENERGY CONSERVATION TAX CREDITS (15 PERCENT)

This option would provide for a 15 percent tax credit to individuals (as compared to the renewable energy credit of 30 percent) for the purchase of residential wood burning equipment. It applies to equipment that is retrofitted on principal residences that were substantially completed before April 20, 1977. Under this provision, the combined limit of all conservation expenditures including insulation, furnace modifications, plus wood burning equipment would be $\$ 2.000$.

\section{Pros:}

- The 15 percent credit will result in a significant increase in demand for wood burning equipment, but this demand will likely be somewhat lower than for the 30 percent renewable energy tax credit. However, a number of manufacturers indicated during the course of this study that i.t is the-existence of the tax credit, rather than the level of the credit, that will be significant in stimulating demand.

- The estimated equivalent oil savings resulting from this option is between 120 and 210 milizion bbl cumulative through the year 2005 depending on the types of equipment eligible. These savings are approximately half of the projected savings for option I, Renewable Energy Tax Credits. The balance of payment impact of this option will also be lower than in the case of option I.

- The estimated Federal tax revenue losises associated with this option are lower than for renewable energy tax credits and lower than the previous tax credit bills, but are still significant, ranging from $\$ 300$ million to $\$ 2$ billion.

\section{- Cons:}

The level of tax credit has no effect on a number of disadvantages listed under option I including:

- Potential safety problems 


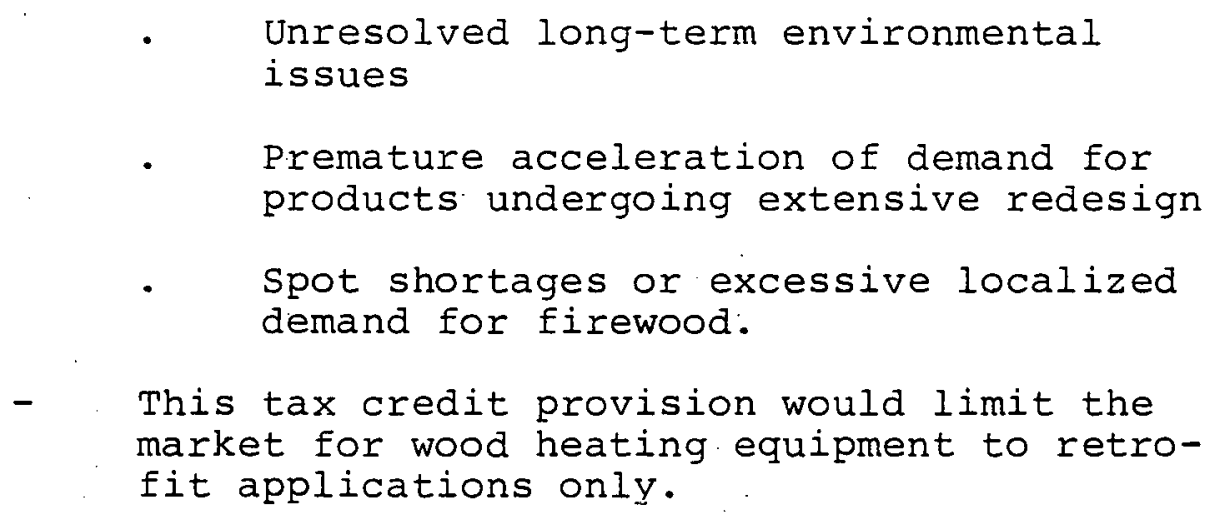

4. SUBOPTION A - AIRTIGHT STOVES ONLY

Although there is relatively little efficiency test data for specific stove models, it is generally recognized that airtight stoves including thermostatic circulators and radiant heaters have the highest efficiency (i.e., 50 to 60 percent) among the types of equipment available. In lieu of more precise efficiency data, this option would allow credit eligibility based on high performance stoves.

\section{Pros:}

- Tax credits for airtight stoves will encourage consumers to purchase higher efficiency equipment.

- Manufacturers will be encouraged to produce and market higher efficiency equipment.

- The government cost per barrel of oil saved for this option is approximately $\$ 3 / b b l$ and is nearly as low as home insulation tax credits (see Exhibit III-4).

Cons:

- The limited eligibility under this option excludes some types of equipment (i.e., Franklin fireplaces) that may perform nearly as well as airtight stoves in some circumstances

- Due to the wide range of efficiencies among airtight stoves, providing credits to this category may promote the use of some inefficient, unsafe, and low quality units. 


\title{
5. SUBOPTION B - ALL STOVES OTHER THAN AIRTIGHTS
}

In addition to airtight units, there are many other styles of stoves on the market, some of which are quite popular for supplemental heating. These include Franklin, boxwood, potbelly, cooking and parlor stoves. Under some circumstances, certain units can operate quite efficiently and often are less expensive than airtight circulators or radiant heaters. (This suboption could be combined with Suboption $A$ above to help eliminate potential confusion as to what types of stoves qualify for tax credit.)

\author{
PrOS: \\ - Average costs for these units are often one- \\ third to one-half that of airtight stoves \\ - The marginal government cost per barrel of \\ oil saved is between $\$ 4$ and $\$ 5$ per barrel \\ depending on the tax credit level. \\ - The option may generate a wider response from \\ potential woodburners. \\ - Since the cost of non-airtight units is gen- \\ erally lower, the per unit tax loss to the \\ government may be reduced. \\ - Cons: \\ - Efficiencies for these units range from 20 to \\ 40 percent compared to 50 percent or more for \\ typical airtight units \\ - Some models do not have firebrick lining or \\ adequate metal thickness, and as a result \\ often "burn out" much sooner than airtight \\ models \\ - Many units cannot meet UL building code stan- \\ dards without extensive redesign.

\section{SUBOPTION C - FURNACES AND BOILERS} \\ Wood fired central heating systems for homes are gaining \\ in popularity especially where the furnace or boiler is a dual \\ fuel unit (i.e., burns wood and oil, or wood and gas). \\ These units can supply a major portion of a home's heating
}


requirements at an efficiency comparable to that of an airtight wood stove.

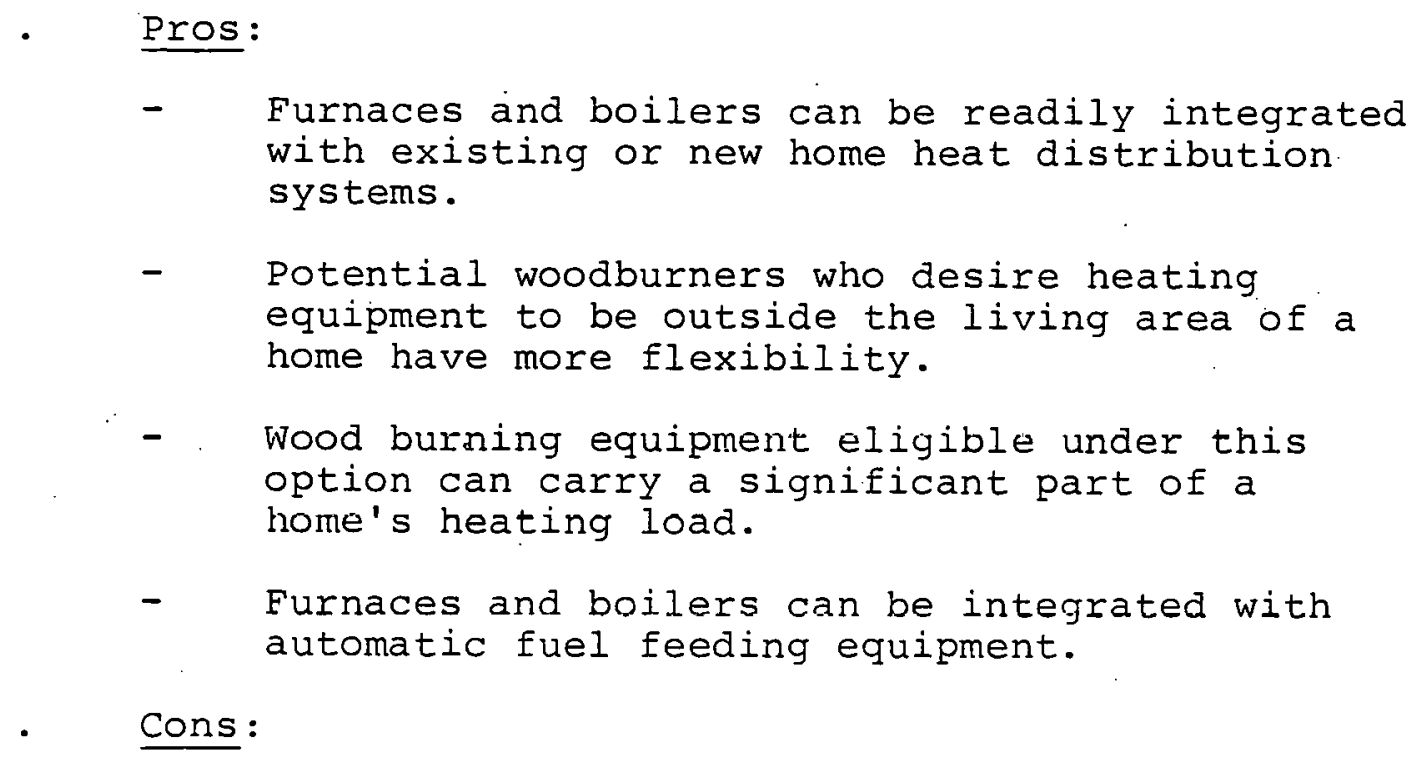

- Combustion efficiency with back-up fuel is lower than for conventional fuel fired heating equipment.

- Many U.S. manufactured products are undergoing intensive development.

- The marginal government tax revenue loss per bbl. of oil saved is somewhat worse than for airtight stoves but approximately the same as Suboption B, All Other Stoves.

\section{\% SUBOPTION D - FIREPLACES}

Currently fireplaces are installed in upwards of 50 percent of all new single family homes and as such constitute the largest single source of potential residential wood usage. However most fireplaces are inefficient compared to wood stoves. This option would extend tax credit to both new and retrofitted fireplaces if renewable energy tax credits apply (Option I) but only retrofitted units if conservation tax credits apply (Option II). 


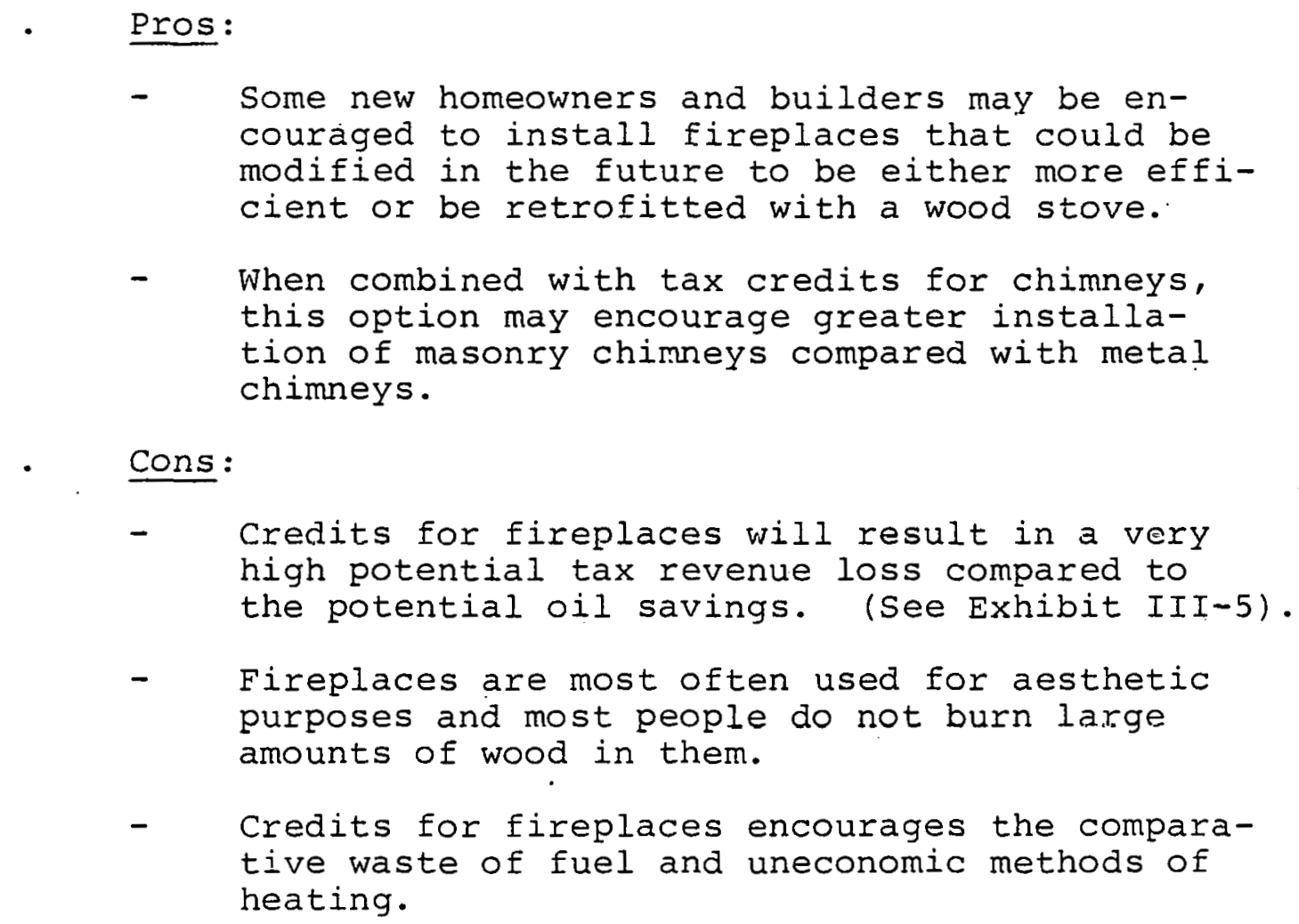

8. SUBOPTION E - CHIMNEYS AND AUXILIARY EQUIPMENT

A key part of safe wood heating equipment operation is a good chimney. A good chimney is clostly however, and can nearly double the cost of a wood stove or furnace alone. As a result, many potential wood burners may be dissuaded from purchasing equipment if a new chimney must be installed. This option would provide for tax credits for new and/or retrofit chimneys for wood burning equipment, depending on the tax credit level option (i.e., Options I or II).

Pros:

- Some new home owners and builders may be encouraged to install higher cost but more durable masonry chimneys at the time a house is built.

- Potential wood burners will be encouraged to install a good chimney along with other wood heating equipment since both would be eligitle for tax credits. 
- Tax credits for chimneys and auxiliary wood burning equipment would improve overall consumer economies.

Cons:

- From the government perspective there is a very substantial tax revenue loss for chimneys over that for wood heating equipment alone. (See Exhibit III-5, Option I, $A+B+C+D+E, 2, a)$.

- Some people may use the tax credits as a subsidy for decorative chimney styles.

\section{-9. SUBOPTION 1 - ALLOW RETROACTIVE ELIGIBILITY}

When the NEA was finally passed by Congress in November 1978, eligibility for conservation and alternative energy equipment was made retroactive to April 20, 1977, the date President Carter first announced the National Energy Plan. If wood heating equipment were added to the eligibility list the date of eligibility could be as far back as this date.

\section{Pros:}

- Retroactive eligibility would tend to put wood heating on an equal basis with other conservation measures in terms of the length of the applicable period.

- There would be a degree of equity for people who already installed wood heating equipment under the belief that a tax refund would eventually be available.

Cons:

- Under the original National Energy Plan there was no specific mention of tax credits for residential use of biomass energy, only for business use as a substitute to oil or gas. Thus, there is no specific administrative obligation to make this particular credit item retroactive. 
- The revenue that would be allotted to tax credits for previous installations, might be better spent on encouraging future installation rather than helping pay off old ones.

10. SUBOPTION 2 - PROVIDE FOR IMMEDIATE ELIGIBILITY (i.e., JANUARY 1,1979$)$

This option would give immediate stimulus to the market for residential wood burning equipment. The actual eligibility date could be varied slightly depending on IRS requirements.

- Pros:

- Immediate eligibility will provide an immediate stimulus to potential wood energy users and would likely have a positive impact on sales for calendar year 1979.

- Potential energy savings due to tax credits will be maximized.

- Cons:

- A jump in fire and safety related accidents could result unless a workable system of standards is implemented.

- Manufacturers may be encouraged to promote current products at the expense of long-term product improvement.

- Immediate eligibility may lead to price increases which would be inconsistent with the government's efforts to curb inflation.

11. SUBOPTION 3 - DELAY ELIGIBILITY (i.e., UNTIL JANUARY 1,1980 )

If DOE does decide to recommend tax credit eligibility for home wood heating equipment, then this option gives the industry and users the incentives being sought but also gives strong impetus to the rapid development of equipment able to meet safety and performance standards. 


\begin{tabular}{|c|c|}
\hline- & $\begin{array}{l}\text { Delayed eligibility "buys time" for the com- } \\
\text { pletion of proposed efficiency standards now } \\
\text { being developed by Auburn University } \\
\text { in conjunction with the Fireplace } \\
\text { Institute. }\end{array}$ \\
\hline- & $\begin{array}{l}\text { It also "buys time" for the testing } \\
\text { and certification of units according } \\
\text { to a recognized safety standard, such } \\
\text { as ULl } 482 \text {. }\end{array}$ \\
\hline- & $\begin{array}{l}\text { By requiring eligible units to meet a } \\
\text { uniformly applicable set of equipment } \\
\text { standards, the tax credit program would } \\
\text { help bring the entire wood heating } \\
\text { equipment industry up to a uniform } \\
\text { level of performance and could help } \\
\text { accelerate product development. }\end{array}$ \\
\hline Cons: & \\
\hline- & $\begin{array}{l}\text { Many stove purchasers may wait until tax } \\
\text { credits are available, thus resulting in low } \\
\text { sales and high dealer inventories in the } \\
\text { near term. (Lowered prices of wood burning } \\
\text { units may result.) }\end{array}$ \\
\hline - & $\begin{array}{l}\text { The potential national oil savings from tax } \\
\text { credits will be reduced by about } 12 \text { percent }\end{array}$ \\
\hline
\end{tabular}

\section{SUBOPTION a - NO MANDATORY STANDARDS}

There are a number of types of standards that could be applied to residential wood burning equipment as a prerequisite for Federal tax credit eligibility. These standards include:

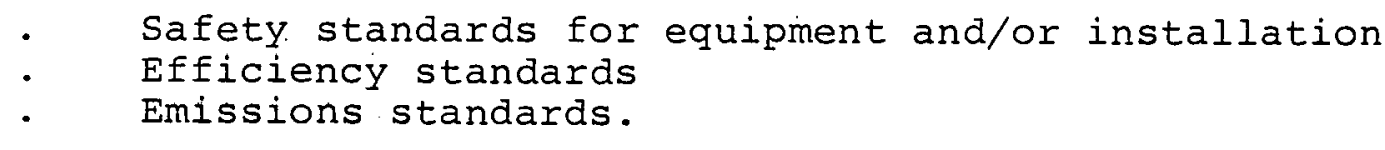

Currently the wood burning equipment industry and several Federal organizations are in the process of developing standards in these areas. Thus, DOE's role could be to assist in the rapid establishment and implementation of proposed voluntary standards, rather than requiring them as a condition of eligibility for a tax credit. The advantages and 
disadvantages of the "no mandatory standards" option are summarized below:

Pros:

- Industry associations and Underwriters Lab are already developing equipment safety standards but it will be at least a year before all major models of equipment can be tested and rated according to these standards.

- Efficiency standards are not as far along in development and there are no proposed emission standards. Thus, there could be a several year delay caused by making eligibility for a tax credit dependent on a series of regulatory actions for these types of standards.

- IRS prefers to keep tax credit forms and instructions as simple as possible and to avoid having to "police" compilance with tax credit eligibility requirements.

- There is also a concern that industry developed concensus standards will not adequately protect consumer interests.

\section{- Cons:}

- A no standards option would discourage the development and implementation of safety, efficiency and emission standards.

- Omitting standard requirements would discriminate against manufacturers which have already invested in the redesigning and testing of units to meet certain standards.

- The Federal government through this option would appear to neglect safety, energy saving and environmental issues. 


\title{
13. SUBOPTION b - SAFETY STANDARDS
}

There are several alternative ways that standards could be used to regulate the safety aspects of residential wood burning.

\author{
Require equipment to be listed by U.L. or a \\ national building code organization \\ Require that installations be inspected by a \\ local building inspector or fire marshal \\ Require owners to certify that the installation \\ process followed a prescribed set of guidelines:
}

One or more of these alternatives could be adopted if this Suboption were implemented.

\section{Pros:}

- Government actions to adopt this suboption would demonstrate its concern with public safety issues.

- Industry adoption of and compliance with a uniform set of safety standards would be accelerated.

- Adoption of this standard would further demonstrate support for manufacturers who already made responsible decisions to comply with safety standards.

- Equipment safety standards for most types of wood burning equipment have been developed by U.L. and testing according to these standards is already underway. A number of the popular units from most major manufacturers have already been tested and rated by UL.

- Encouraging compliance with safety standards may reduce the incidence of woodburner related fires.

\section{Cons:}

- An increasing number of local governments already require a building permit and inspection when wood burning equipment is installed, 


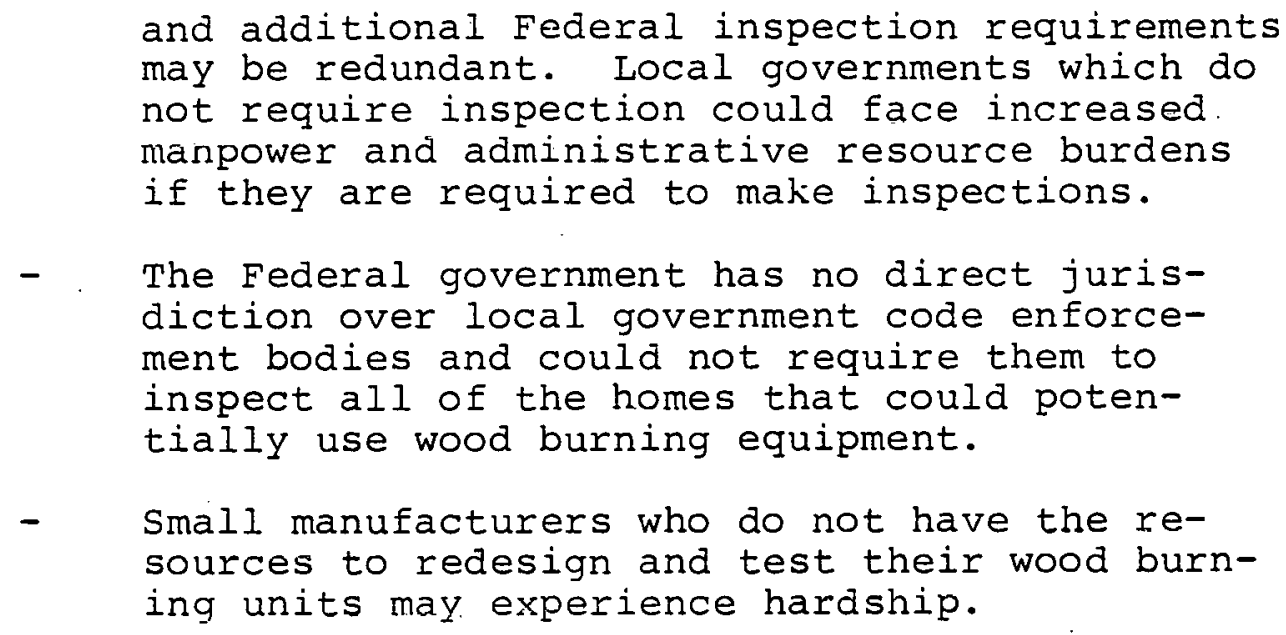

\section{SUBOPTION C - EFFICIENCY STANDARDS}

With the wide variance in efficiencies for wood burning equipment, a minimum level of efficiency as a prerequisite for tax credit eligibility could be implemented through equipment efficiency standards.

\section{Pros:}

- The adoption of this option would demonstrate the government's concern with energy conservation. Already, at least 40 percent of present wood:stove sales consist of units that have efficiencies below what would be considered acceptable from the standpoint of economical operation.

- Local building codes normally do not address equipment efficiency, only safety; thus the. only possible regulation of efficiency is through Federal action.

- The technology for efficient equipment is well understood and readily available to manufacturers. The adoption of this suboption would encourage the implementation of these technologies. 
- Cons:

- It will likely be at least six months before a suitable efficiency test standard can be finalized and at least another one to two years before the majority of models on the market could be tested in a laboratory according to a standard procedure.

- Equipment efficiency ratings do not adaress the problem of lowered performance due to improper installation.

- Local governments may resist new Federally mandated requirements that would cause increased costs of administration.

\section{SUBOPTION d - EMISSIONS STANDARDS}

The concern over potential air pollution resulting from increased use of wood burning equipment could be addressed through imposing emissions standards for wood stoves and other equipment. Thus, this suboption is to require stoves to meet equipment design and certification standards. Such requirements would be analogous to UL ratings.

\section{Pros:}

- Particulate emissions under some circumstances, càn be hïgher for wood stoves than for conventional fuel fired heating equipment; standards could potentially help control this problem.

\section{Cons:}

- Wood burning equipment emissions testing is currently in the research stage and development of any equipment related standards is likely to be several years away

- There is a question as to whether emissions caused by residential wood burning equipment will significantly increase air pollutión problems given that most wood users are dispersed throughout rural areas. 